\title{
Verkhnee Gakvari: The contribution of adat, religious beliefs and public education to collective environmental management in an agro-pastoral community in the Dagestan high Caucasus
}

\author{
Guy Petherbridge ${ }^{1}$, Magomed M. Ismailov ${ }^{2}$, Shamil M. Ismailov ${ }^{2}$, Murtazali Kh. Rabadanov ${ }^{1}$, \\ Alimurad A. Gadzhiev ${ }^{1}$, Abdulgamid A. Teymurov ${ }^{1}$, Murtuzali R. Rabadanov ${ }^{1}$, Madina G. Daudova ${ }^{1}$ \\ and Abdul-Gamid M. Abdulaev ${ }^{1}$ \\ ${ }^{1}$ Dagestan State University, Makhachkala, Russia \\ ${ }^{2}$ Verkhnee Gakvari School, Verkhnee Gakvari, Russia
}

\section{Principal contact}

Guy Petherbridge, Professor, Caspian Centre for Nature Conservation, Institute of Ecology and Sustainable Development, Dagestan State University; 21 Dakhadaeva St, Makhachkala, Russia 367000 .

Tel. +79886340050

Email caspianconservation@mail.ru ORCID https://orcid.org/0000-0001-7196-3937

\section{How to cite this article}

Petherbridge G., Ismailov M.M., Ismailov Sh.M., Rabadanov M.Kh., Gadzhiev A.A., Teymurov A.A., Rabadanov M.R., Daudova M.G., Abdulaev A.-G.M. Verkhnee Gakvari: The contribution of adat, religious beliefs and public education to collective environmental management in an agro-pastoral community in the Dagestan high Caucasus. South of Russia: ecology, development. 2021, vol. 16, no. 3, pp. 142-179. DOI: 10.18470/1992-1098-2021-3142-179

Received 28 June 2021

Revised 14 July 2021

Accepted 15 August 2021

\begin{abstract}
Aim. To examine the contribution structured systems of social mores (adat) and religious and secular public education have made to developing and sustaining socio-ecological environment management in one community, Verkhnee Gakvari, in the upper valley of the Andiiskoe Koisu in the Dagestan Caucasus, from deep antiquity to the present day.

Discussion. The research involved an extensive review of the relevant literature and on-line resources dedicated of the region. Communities were visited across the region and discussions were undertaken with their representatives, as well as with other stakeholders. A particular emphasis was placed on the exemplary system of environmental education provided at the Verkhnee Gakvari School and its positive impact in sustaining the socio-ecological production landscape of its territory. Significant progress was made in researching and documenting the range of issues fundamental to understanding the formation and continuity of the interdependencies with nature and the cultural landscapes unique to these agro-pastoral cultures of the upper Andiiskoe Koisu. This includes a comprehensive documentation of the contributions the Verkhnee Gakvari School has made to the preservation of its community's socio-ecological production landscape.

Conclusion. Verkhnee Gakvari and other traditional communities of the upper Andiiskoe Koisu present a unique multi-millenial cultural continuum of global significance for understanding the evolution of human society and are a remarkable survival in Europe of successful and harmonious socio-ecological production landscape interdependencies. As the combined impacts of modern society and climate change now inevitably impinge upon the ability of the inhabitants of this ancient homeland to sustain the benefits which they have so successfully crafted from their environment, the region is in priority need of national and international recognition and support.
\end{abstract}

\section{Key Words}

Socio-ecological production landscape, environmental management, agropastoral community, Dagestan, Caucasus. 


\title{
Верхнее Гаквари: вклад адата, религиозных убеждений и народного образования в коллективное управление окружающей средой в агро-пастырском сообществе Дагестанской части Большого Кавказа
}

\author{
Гай Петербридж ${ }^{1}$, Магомед М. Исмаилов ${ }^{2}$, Шамиль М. Исмаилов ${ }^{2}$, Муртазали Х. Рабаданов ${ }^{1}$, \\ Алимурад А. Гаджиев ${ }^{1}$, Абдулгамид А. Теймуров ${ }^{1}$, Муртузали Р. Рабаданов ${ }^{1}$, Мадина Г. Даудова ${ }^{1}$, \\ Абдул-Гамид М. Абдулаев ${ }^{1}$ \\ ${ }^{1}$ Дагестанский государственный университет, Махачкала, Россия \\ ${ }^{2}$ Верхнегакваринская Школа-Сад, Верхнее Гаквари, Россия
}

\author{
Контактное лицо \\ Гай Петербридж, Профессор, Каспийский \\ центр охраны природы, Институт экологии \\ устойчивого развития, Дагестанский \\ государственный университет; 367001 \\ Россия, г. Махачкала, ул. Дахадаева, 21. \\ Тел. +79886340050 \\ Email caspianconservation@mail.ru \\ ORCID https://orcid.org/0000-0001-7196- \\ $\underline{3937}$
}

\section{Формат цитирования}

Петербридж Г., Исмаилов М.М., Исмаилов Ш.М., Рабаданов М.Х., Гаджиев А.А., Теймуров А.А., Рабаданов М.Р., Даудова М.Г., Абдулаев А.-Г.М. Верхнее Гаквари: вклад адата, религиозных убеждений и народного образования в коллективное управление окружающей средой в агро-пастырском сообществе Дагестанской части Большого Кавказа // Юг России: экология, развитие. 2021. T.16, N 3. C. $142-179$. DOI: 10.18470/1992-1098-2021-3-142-179

Получена 28 июня 2021 г.

Прошла рецензирование 14 июля 2021 г. Принята 15 августа 2021 г.

\begin{abstract}
Резюме
Цель. Изучить вклад структурированных систем социальных нравов (адатов), религиозного и светского государственного образования в развитие и поддержание управления социально-экологической среды в сообществе Верхнее Гаквари, расположенном на верхнем участке р. Андийское Койсу в высокогорном Дагестане от глубокой древности до наших дней.

Результаты. Исследование включало обширный обзор соответствующей литературы и онлайн-ресурсов, посвященных региону. Посетили сообщества по всему региону и провели обсуждения с их представителями, а также с другими заинтересованными сторонами. Особый акцент был сделан на образцовой системе экологического образования в школе Верхнее Гаквари и ее положительном влиянии на сохранение социально-экологического производственного ландшафта территории. Значительный прогресс был достигнут в исследовании и документировании ряда фундаментальных вопросов для понимания, формирования и непрерывности взаимозависимостей с природными и культурными ландшафтами, уникальными для этих агро-пастбищных систем верхнего участка р. Андийского Койсу. Это включает в себя исчерпывающую документацию о вкладе школы Верхнее Гаквари в сохранение социально-экологического производственного ландшафта своего сообщества.

Заключение. Верхнее Гаквари и другие традиционные сообщества верхнего участка р. Андийского Койсу представляют собой уникальный многовековой культурный континуум глобального значения для понимания эволюции человеческого общества и являются удивительным пережитком с гармоничной взаимозависимостью социальноэкологического производственного ландшафта. Современное общество и климатические изменения оказывают влияние на возможность сохранения природных благ жителями этой древней родины. Таким образом, рассматриваемый регион в первую очередь нуждается в государственной поддержке и международном признании.

Ключевые слова

Социально-экологический производственный ландшафт, природопользование, агро-пасторальное сообщество, Дагестан, Кавказ.
\end{abstract}

(C) 2021 Авторы. Юг России: экология, развитие. Это статья открытого доступа в соответствии с условиями Сreative Соmmons Attribution License, которая разрешает использование, распространение и воспроизведение на любом носителе при условии правильного цитирования оригинальной работы. 


\section{INTRODUCTION}

This study was undertaken to document and raise awareness of the long, undisrupted course of human occupation in harmony with nature of the upper Andiiskoe Koisu region in the high Caucasus of Dagestan from the perspective of the role played by social mores (adat) and religious and secular education in collective environmental management with a focus on the exemplary contributions of the Verkhnee Gakvari community and its school.

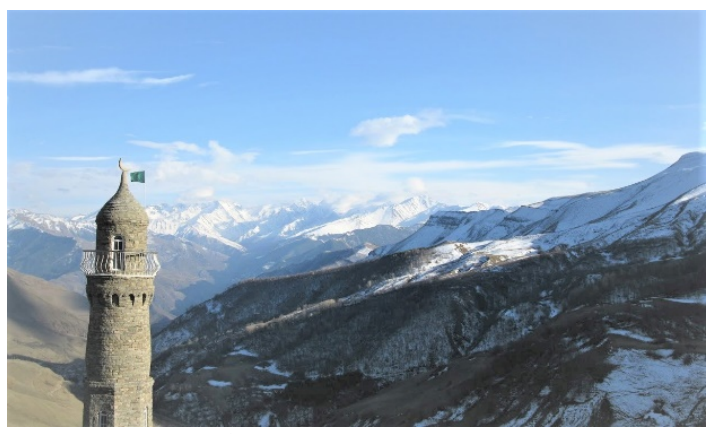

Figure 1. Minaret of Verkhnee Gakvari: View across the Andiiskoe Koisu to the Bogossky Ridge

Here, as climatic conditions gradually ameliorated following the last Ice Age, a complex of post-glacial high altitude landforms were ultimately to provide a home for the rich and diverse range of alpine and subalpine flora and fauna and habitats which characterize the region today. Man, having survived in the glacial refugia provided by the adjacent lowlands of Transcaucasia following the first appearance of hominids in Eurasia there some 1.8 million years ago, was to return to hunt and forage and find a uniquely compatible ecosystem, sheltered by geology from outside view and intrusion and blessed by nurturing microclimates and bounteous soils. By some 6,000 years ago, Neolithic man was optimizing a range of fertile bio-
Three interconnecting rivers systems (Koisu) drain the inner fastnesses of the south-west of the Dagestan Caucasus. The turbulent headwaters of the most remote of them, the Andiiskoe Koisu, slice a dramatic course amongst towering snowy ranges, still being sculpted by remnant glaciers of the great ice sheet which enclosed the entire high Caucasus during the last Ice Age (c. 110,000-11,000 years ago) [1-12].

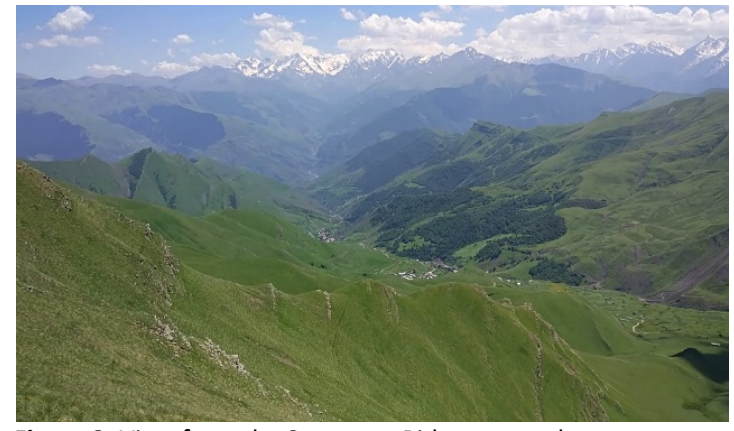

Figure 2. View from the Snegovoy Ridge across the valley of the Gakvarinka River and the territories of Verkhnee and Nizhnee Gakvari to the Andiiskoe Koisu and the Bogossky Ridge

niches in the Dagestan highlands for permanent habitation on the basis of high altitude cereal-based agriculture and stock-raising, maximizing the benefits of what nature had to offer and in symbiosis and co-evolution with it [13].

For the first $50 \mathrm{~km}$ of its course the Andiiskoe Koisu cuts a massive south-north gorge through a post-glacial topography fed by deeply incised tributary valleys on either side flowing off the mountain peaks of the Snegovoy Ridge to the west (highest 4,285 m) and the Bogossky Ridge to the east (highest 4,151 m) [14]. Today this richly geodiverse territory is administratively the Tsudmadinskiy District of Dagestan (Fig. 3-4).

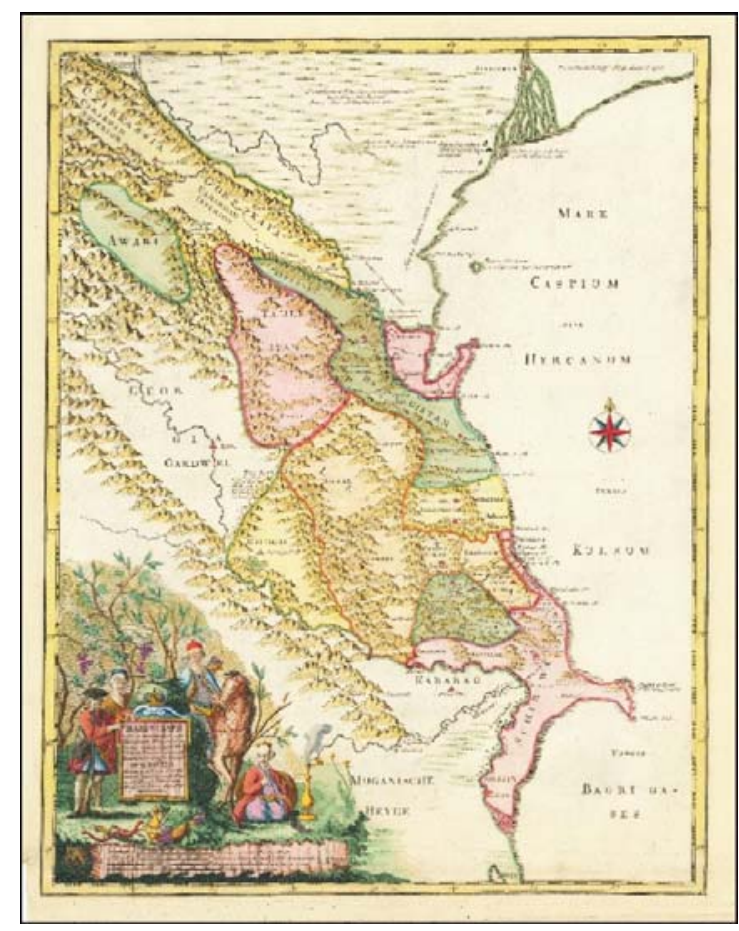

Figure 3. Map of the western Caspian Sea area and eastern Caucasus. First European map to indicate the existence and approximate location of "Awaria" (Avaria), through which runs the Andiiskoe Koisu. By Joseph Nicholas de l'Isle, 1727 


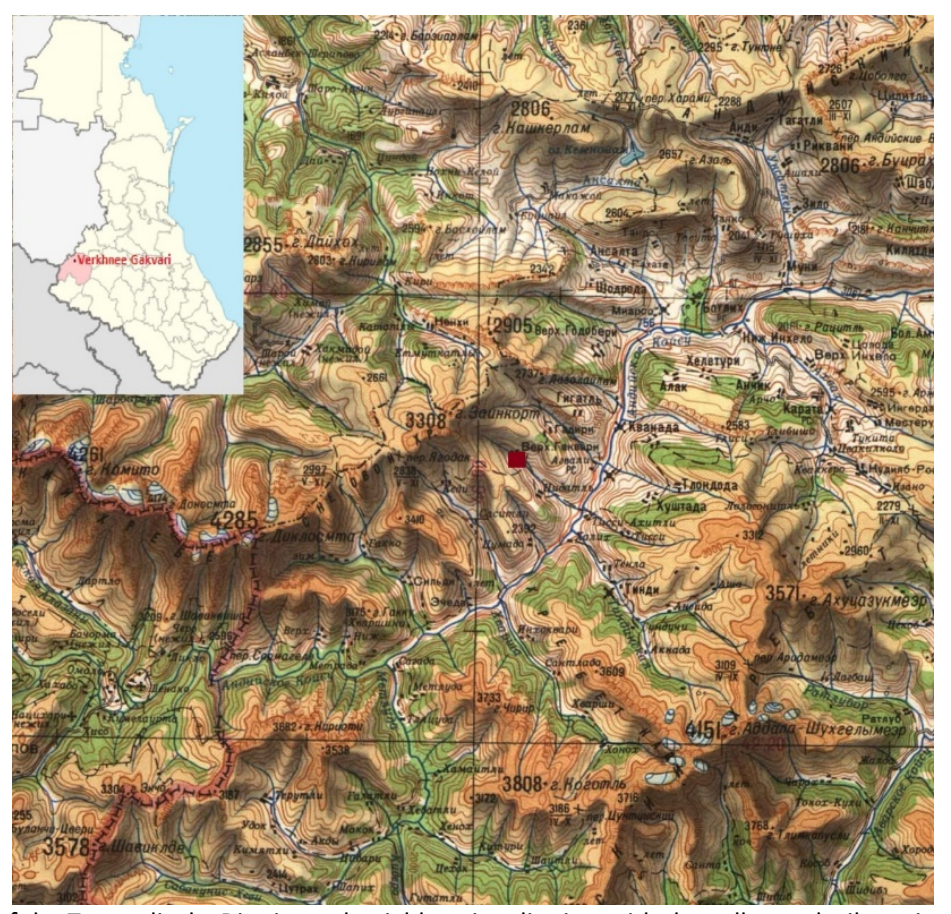

Figure 4. Topographic map of the Tsumadinsky District and neighbouring districts with the valley and tributaries of the Andiiskoe Koisu. Verkhnee Gakvari is located in the valley in the centre of this image. Inset indicates location of the village and district in the Republic of Dagestan

The Andiiskoe Koisu eventually changes to a more open course to the northeast below the regional agricultural and market centre of Botlikh as the geology abruptly changes, allowing orchard and other crops to be grown in broad man-made stone-walled terraces along the river banks in an area of rain shadow which is drier than the moister upper reaches.

Upstream the settlers of the communities of the north-central upper headwaters region of the Andiiskoe Koisu chose to occupy and optimize unique geomorphological and associated ecological resources of fertile pockets of arable alluvial and glacial soils which had accumulated between sub-alpine and alpine altitudinal zones in each of the tributary valley systems feeding into the Koisu.

The equitable microclimate which characterizes the north-central section of the headwaters gorges and tributary valleys was an important factor in the choice of settlement locations in terms of both human comfort and mobility and agricultural requirements. Winters are rarely extremely cold and snow generally did not lie on the ground for long periods, there being persistent snow cover only on the highest peaks bordering the Koisu. Summers are mild and sunny with frequent downpours of rain. Of major significance also was that these altitudes were above the "fever zone", the areas of endemic malaria which plagued populations of the coastal lowlands and lower levels of the river systems of Dagestan [15]. High mountain crops likewise were little affected by the insect pests to which they were subjected in lowland areas.

Unlike in many other parts of highland Dagestan, where much ingenuity, time and effort has been expended over many millennia in constructing substantial tiers of terraced fields to retain sparse soil resources, post-glacial pockets of deep argillaceous soil in the north-central landscapes of the headwaters region of the Andiiskoe Koisu were available to be used with much less human engineering effort. The inherent slope stability of these soils meant that terraces sculpted by hoe to create even fields kept their form without masonry retaining walls.

Research into the genetics and linguistic histories of current populations in the headwaters region of the Andiiskoe Koisu indicates that already by some six millennia ago, groups had begun creating what were to become unique cultural enclaves in each of the major tributary zones along the gorge, each developing its own language and ethnic traditions but sharing the same ways of utilizing the landscape and its resources. Today these enclaves (often never larger than a few thousand individuals) survive having preserved their geographic, linguistic and cultural identities intact for thousands of years without any fundamental disruption. Their languages - Godoberi, Botlikh, Chamalal, Bagulal, Tindi and Khvarshi belong to the Avar-Andic-Didoic group. There is also a section in the left central flank of the headwaters region of the Koisu where the indigenous language is Avar (Fig. 5, 6). The combination of geography and patriarchal endogamy has produced a highly structured regional population exhibiting great linguistic diversity, with genetically isolated societies existing more or less autonomously within a relatively small geographic territory [16-27].

The subsistence economies of these agro-pastoral communities evolved with a reliance on benefits (a) produced by man in interaction with and reliance on nature and (b) produced by and directly obtained from nature. Traditional subsistence was based on the cultivation of cereals (much later supplanted by potatoes and corn) and the raising of sheep and the robust, small cattle, as well as the use of products sourced from forests and the vegetation of more open natural habitats. These resources are still the mainstay of existence in the high mountain communities of the Andiiskoe Koisu. 


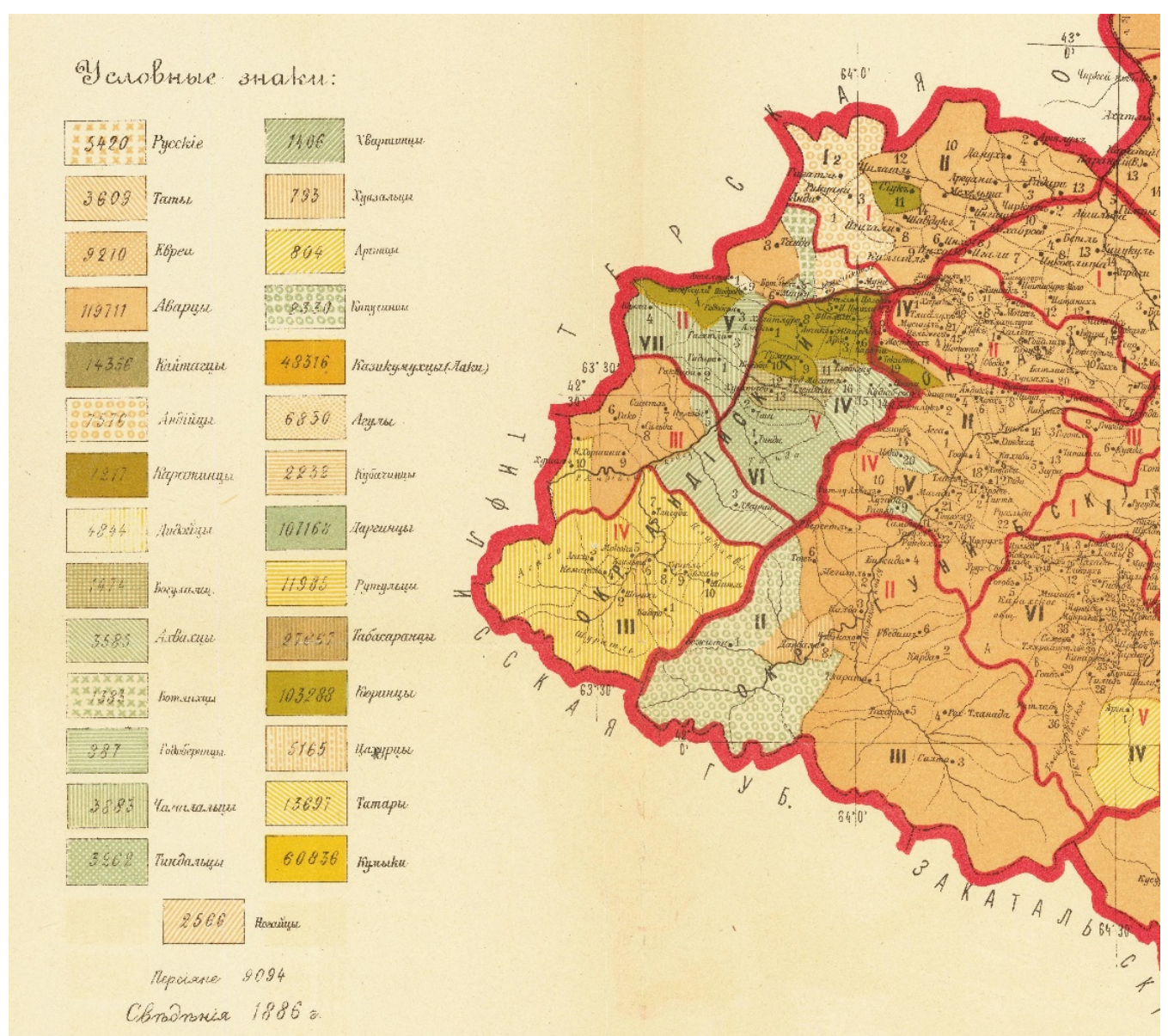

Figure 5. Detail of Russian ethnographic map of the Dagestan oblast of 1886 demarcating the Andiiskoe Okrug and the ethno-linguistic enclaves of the "Botlikhtsi, Godoberintsi, Chamalaltsi, Bogulaltsi, Tindaltsi and Khavarshintsi" The Chamalals numbered 3,883

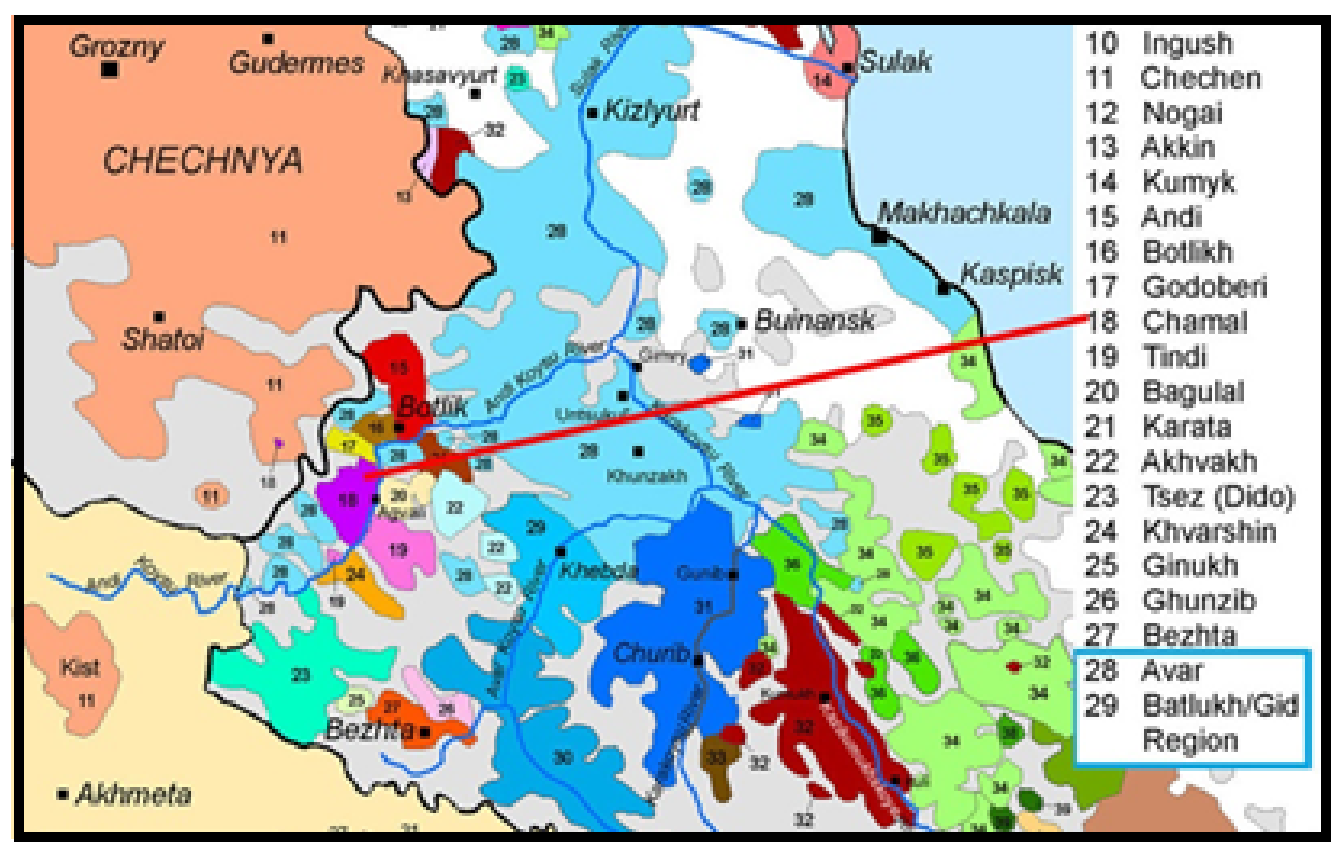

Figure 6. Map showing areas where West Dagestanian languages are spoken: Botlikh, Karata, Chamalal, Bagvalal, Tindi and Avar and the Didoic of Khvarshi

Eco-Functional Altitudinal and Geomorphological Zonation A key feature of the common agro-pastoral culture developed by communities in the region is that their territories are divided according to clear patterns of ecofunctional altitudinal and geomorphological zonation, which, once successfully established, have been consciously maintained for millennia in ways which mirror the Japanese Sotoyama relationships [28].

These functional zones can be schematically represented thus for the generality of high mountain settlements on either side of the Koisu (Fig. 7). 


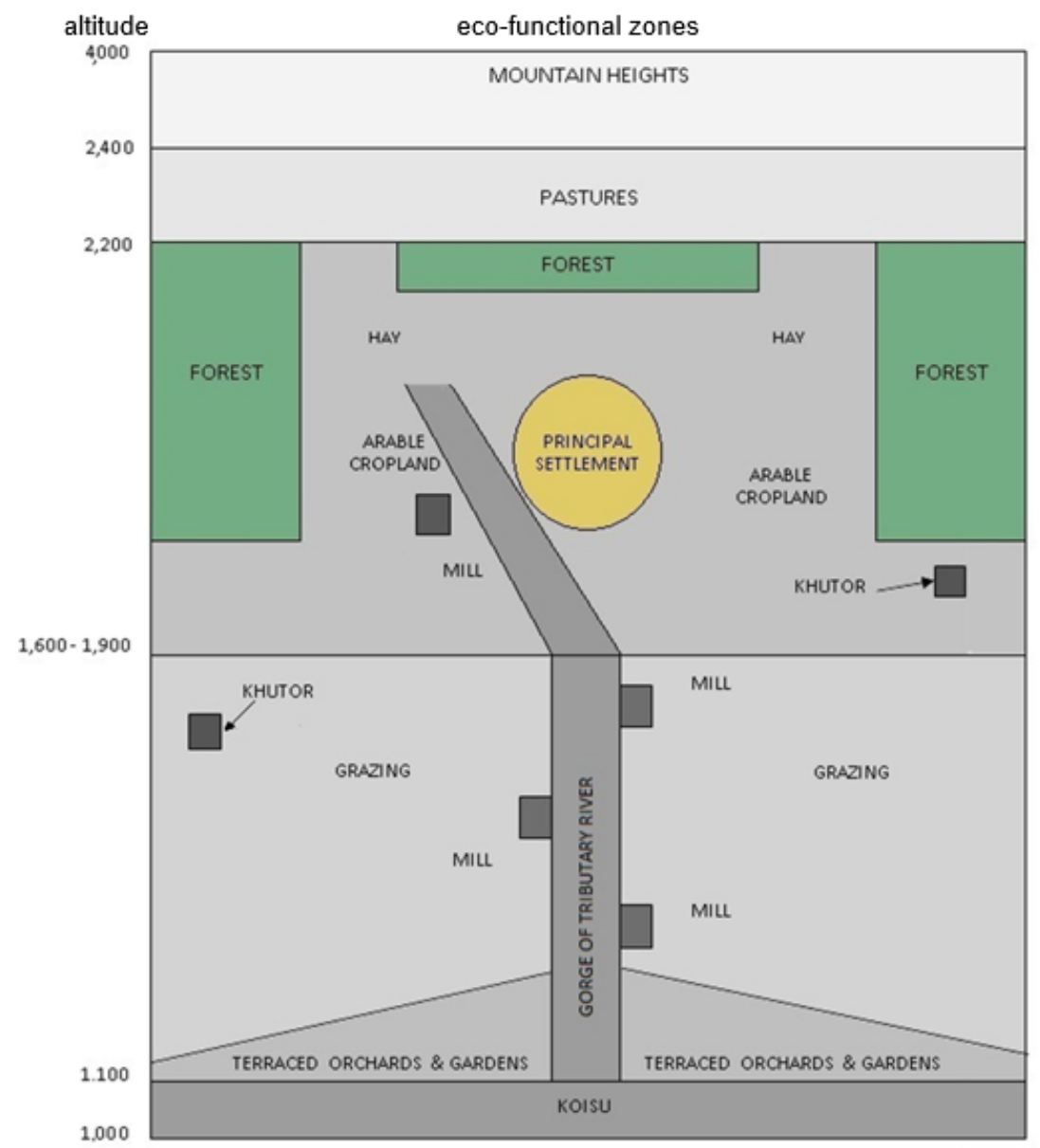

Figure 7. Generalised schematic of eco-functional zones according to altitude of the high mountain communities on either flank of the northern upper reaches of the Andiiskoe Koisu

The principal settlements of the Andiiskoe Koisu valley are all situated at the upper levels of sustainable human comfort in terms of temperature and year-round accessibility within a boundary zone between what are generally accepted as subalpine and alpine altitudes at these latitudes, that is between approximately 1.650 and $2.150 \mathrm{~m}$ asl.

From the level of the Koisu to the high peaks, each settled tributary zone has distinct functions relating to altitude and geomorphology, as follows:

- What is in essence the vertical axis of community territory is a tributary river draining the high peaks behind the settlement and flowing through or adjacent to it.

- An eco-functional zone around the settlement serves as the functional core of a broad area of agricultural cropland (i.e. land ploughed for cereal and other staple cultivation) in an altitude range from sub-alpine to alpine.

- Embracing the settlement area as a whole or not far distant is a considerable area of forest dominated by pine (Pinus sosnowskyi Nakai) in the central region of the upper Koisu where timber is cut for building and fuel and the making of agricultural and other implements. The forest and its periphery is also a resource for a range of edible and medicinal wild plants.

- Above the settlement and core cropland are open lands used as hay fields and for grazing of cattle. At the higher levels of this zone grassy alpine slopes and meadows are used for pasturing flocks of Dagestani mountain fat-tailed sheep in the warmer months until they are driven to distant winter pastures in the piedmonts and plains behind the Caspian coast. Various shrubby plants on the verges of this zone provide a range of edible berries gathered in season.

- At the highest elevations behind the village are untamed rocky wilderness areas of mountain peaks, the habitat of wild game.

- Below the central settlement and agricultural zone, the tributary river characteristically cuts a deep, narrow gorge where watermills are situated to exploit the faster flowing water. The sides of these tributary gorges are used for the free range grazing of cattle and donkeys. Here a range of herbs grows which are collected for domestic use.

- The lowest community territorial zone is where the tributary river meets the main course of the Koisu. Here stone terraced fields are characteristically constructed where orchards of fruit and vegetable may be grown at the higher temperatures there and where there is also the possibility of irrigation.

- Each community territorial zone is linked to its immediate neighbours by a system of well-engineered and maintained trails passable on foot or by donkey at the high altitude levels of the settlements themselves. Travelling by these routes the upland settlements are actually not far from one another and quite accessible by locals. Only since roads were built along the Andiiskoe Koisu have these highland trails been superseded, considerably extending the distance of travel between settlements as the roads follow the river and then up the tributary valleys of each community. 


\section{Core community settlement and cropland zone}

The core settlement of traditional tiered stone-built dwellings and ancillary structures is generally situated within the lower levels or periphery of a substantial agricultural zone used for the growing of cereal crops and hay on tillable boulder-free glacial soil. Soils are ploughed with a wooden plough (fitted with an iron share) usually drawn by two steers of the small local cattle. Settlements

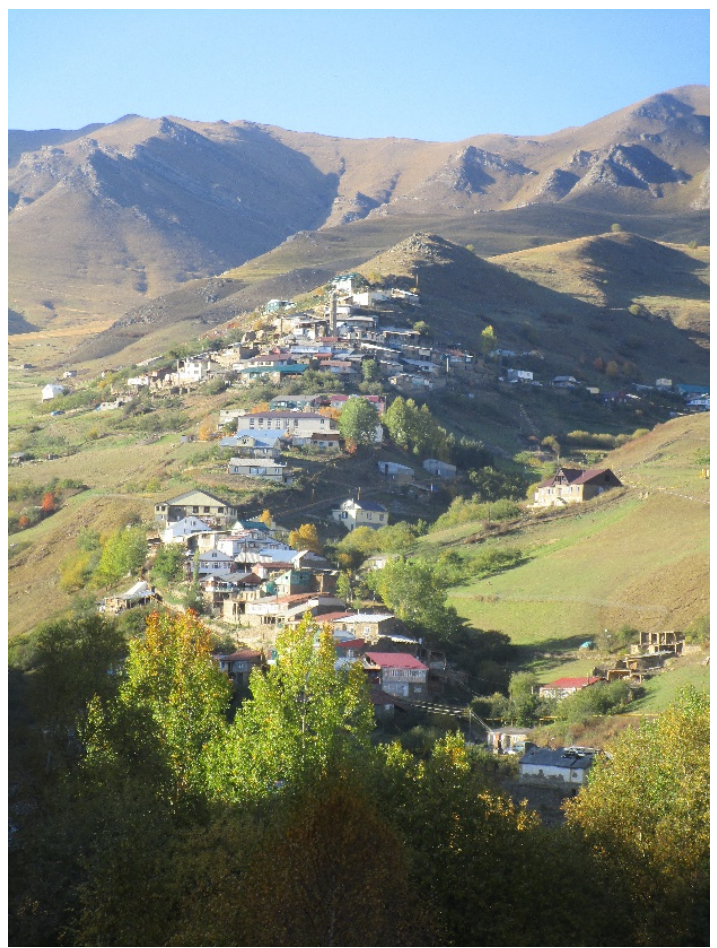

Figure 8. View of village of Verkhnee Gakvari from the east. The microdistrict of Egdada is in the foreground and that of the old village centre and mosque behind. The microdistrict of Mazhbal is in the right centre of the photograph

The larger settlements were distinguished by having a Friday mosque and community cemetery.

Some small villages such as Gigikh, Sasitli and Ssuidi were dependent on the larger ones. They did not have their own cemeteries, meeting place or Friday mosque and matters related to their internal life were decided at gatherings of the larger villages with representatives these smaller settlements.

A key factor in each community's chosen location was the availability of a reliable source of water for drinking and domestic purposes for the settlement itself and for watering gardens and livestock. Throughout the Caucasus sources of drinking water are highly valued for their particular taste or minerals perceived as beneficial to health [29]. Water is also essential for ritual religious ablutions, so much so that immediately adjacent to each central village mosque water is made available either in a separate ablutions room or via a fountain from which water is gathered by local residents for general use. Villagers also pay proper attention to the physical maintenance of particularly valued natural springs in their territories, ensuring that they are clean and accessible and not damaged by livestock. In some cases, like the gushing clear mountain torrent of Inkhokvari in one of the tributaries of the Koisu, they are a source of local pride, their pure waters attracting visitors and revenue to the community.

Traditionally, small hamlets (khutora) used by one or a small group of households, were also built, either on are often built on a rocky outcrop adjacent to or overlooking the axial river tributary which generally bears the name of the cultural group or settlement (e.g. Gakvarinka River) through whose flows its territory. Traditionally the main construction materials for dwellings and service buildings were locally-sourced stone, wood and clay (Fig. 8, 9).

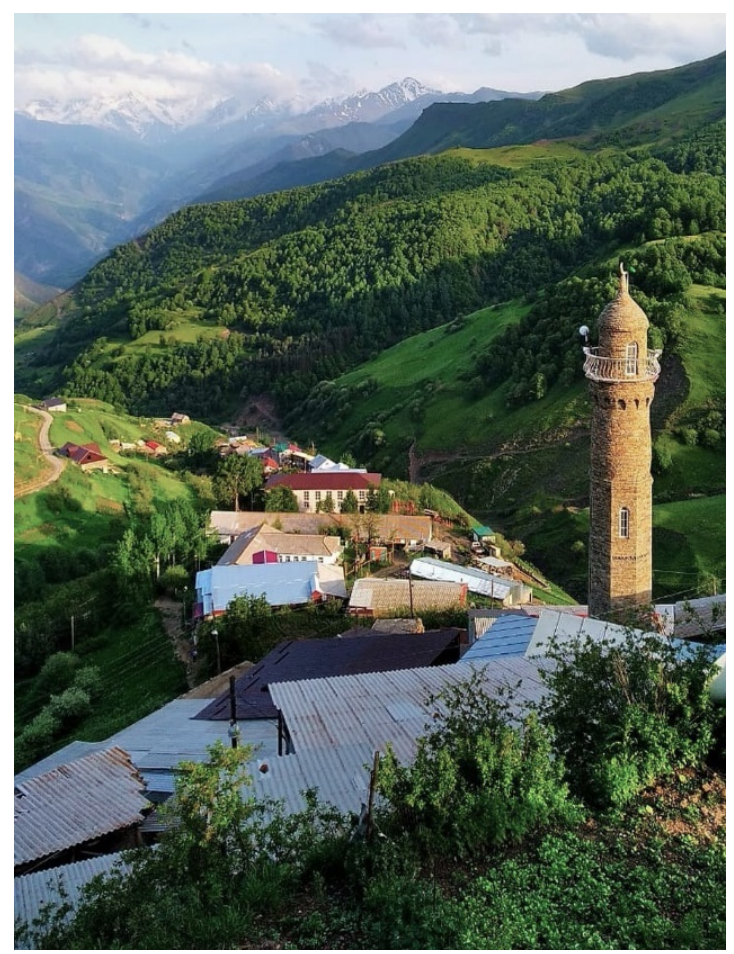

Figure 9. View from the old central quarter of Verkhnee Gakvar to the west with the minaret and microdistrict of Egdada. The Verkhnee Gakvari School is the long building situated horizontally in the centre of the picture

the fringes of community territory for easier access to fields or where springs were available for watering livestock (and where fodder could be stored and animals stabled). These hamlets were not condoned officially during the Soviet period (all residents being required to live in a central collective location) but in some cases they continued to be used as they were the location of essential springs for watering fields and animals [30]. Small mosques or prayer rooms equipped with prayer rugs are often built along trails and roads for the use of whoever may be in the locality at prayer times. There is usually some natural source of water for ablutions nearby.

The major central altitudinal zone of the village territory was that devoted to the growing of cereal staples (Fig. 10-13). Locally adapted winter wheat, winter barley, spelt, rye and oats (many varieties of which were endemic and the result of a very long and process of both natural and purposeful human selection) grew excellently on these soils at these altitudes, although the quantities produced were sometimes insufficient for community needs. Extra grain was bought in regional markets (Botlikh, Khunzakh, Buynaksk) in exchange for dairy products (cheese, butter, and skins) obtained from the village's sheep and cattle (a donkey journey to the latter might take three weeks). Peripheral areas bordering crop land or fields in fallow were used to produce hay which was cut, dried and stored in late summer and autumn as winter fodder for cattle (Fig. 14-17). 


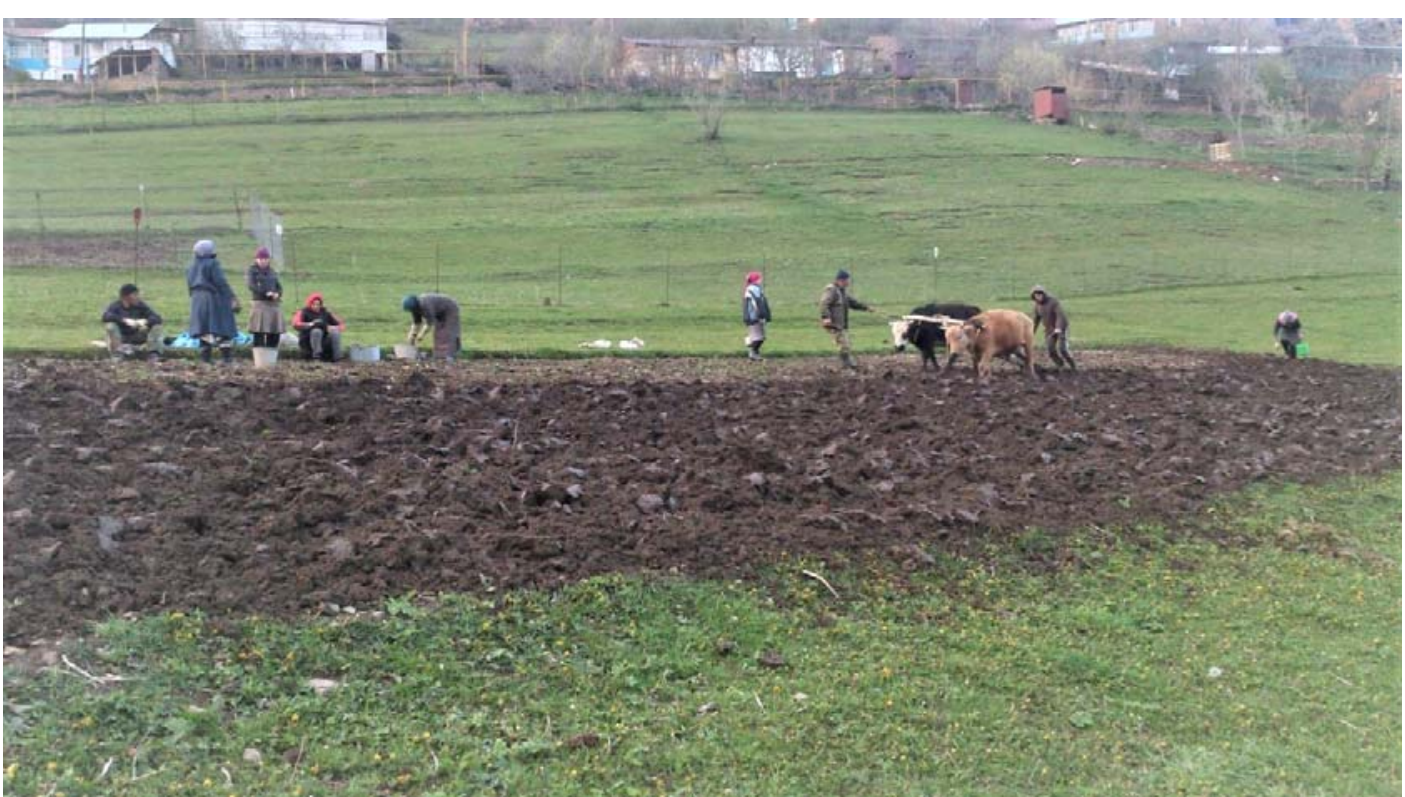

Figure 10. Ploughing a field near the village with steers of the small mountain cattle of Verkhnee Gakvari

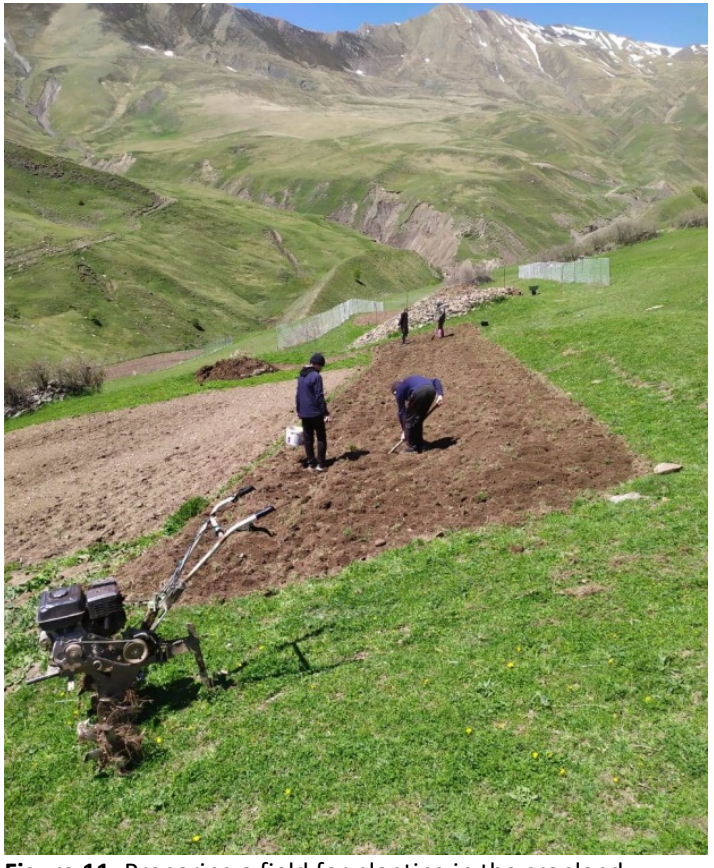

Figure 11. Preparing a field for planting in the cropland above the village of Verkhnee Gakvari. Rotary cultivators are increasingly taking the place of the traditional plough

The principal subsistence agricultural products of these communities prior to the $19^{\text {th }}$ century were grains (wheat, barley, spelt, rye and oats), root vegetables (carrots and beet), cabbages, onions, pumpkins, beans, peas and fruits (apples at high altitudes and apricots - native to the slopes of the upper reaches of the Koisu - at lower, warmer levels), cherries, plums, pears, persimmons, walnuts and grapes. In the $19^{\text {th }}$ century both potatoes and corn were introduced and became staple crops. Following the Soviet state-imposed halt in the 1950s on wheat cultivation in the region, industrially-milled white flour from more central regions of the USSR became widely available and water mills began to close. Corn has become a favoured source of flour for the flat, round, unleavened breads of traditional home cuisines. It is also used for khinkal, the staple "pasta" of much of inland Dagestan (otherwise made from wheat

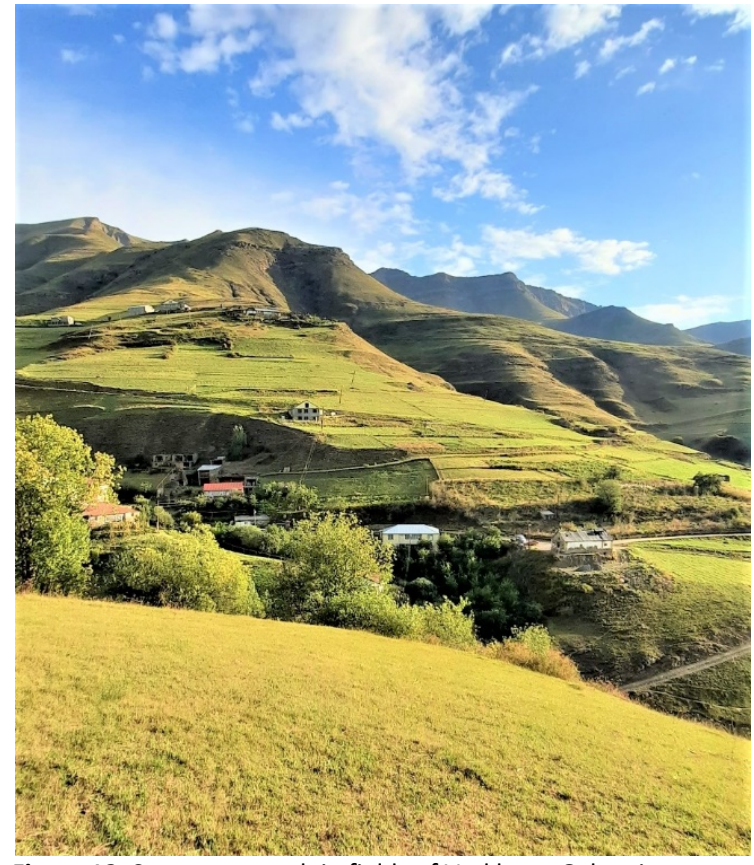

Figure 12. Summer growth in fields of Verkhnee Gakvari

flour). Both wheat and corn flour were also used to make chudu, flat pan-fried cakes filled with nettles, soft cheese, meat or mashed potatoes which are still standard food items. A popular porridge was also prepared from oatmeal (Fig. 18-24).

Although corn is a labour-intensive crop, it is favoured because of its high yield. It is also easy to store. Individuals in certain high altitude communities such as Khvanada sell their own stone-ground flour in the weekly market in the regional centre of Agvali as a premium product in demand because of its organic purity. Potatoes have also become a standard staple crop, easily tended and at these altitudes are not affected by the insect pests which ravage potato fields in some parts of Russia. They are also easily stored. 
One of the principal foods provided by nature is honey; prior to the availability of beet sugar it was the principal sweetener used. Hives are set where wild herbs and trees were in bloom. A noticeable feature of the warm months in the Tsumadinskiy District is the abundance of bees, bumble bees and other insects busily engaged in pollinating cultivated and wild flowers - a testimony to the healthy status of local biodiversity.

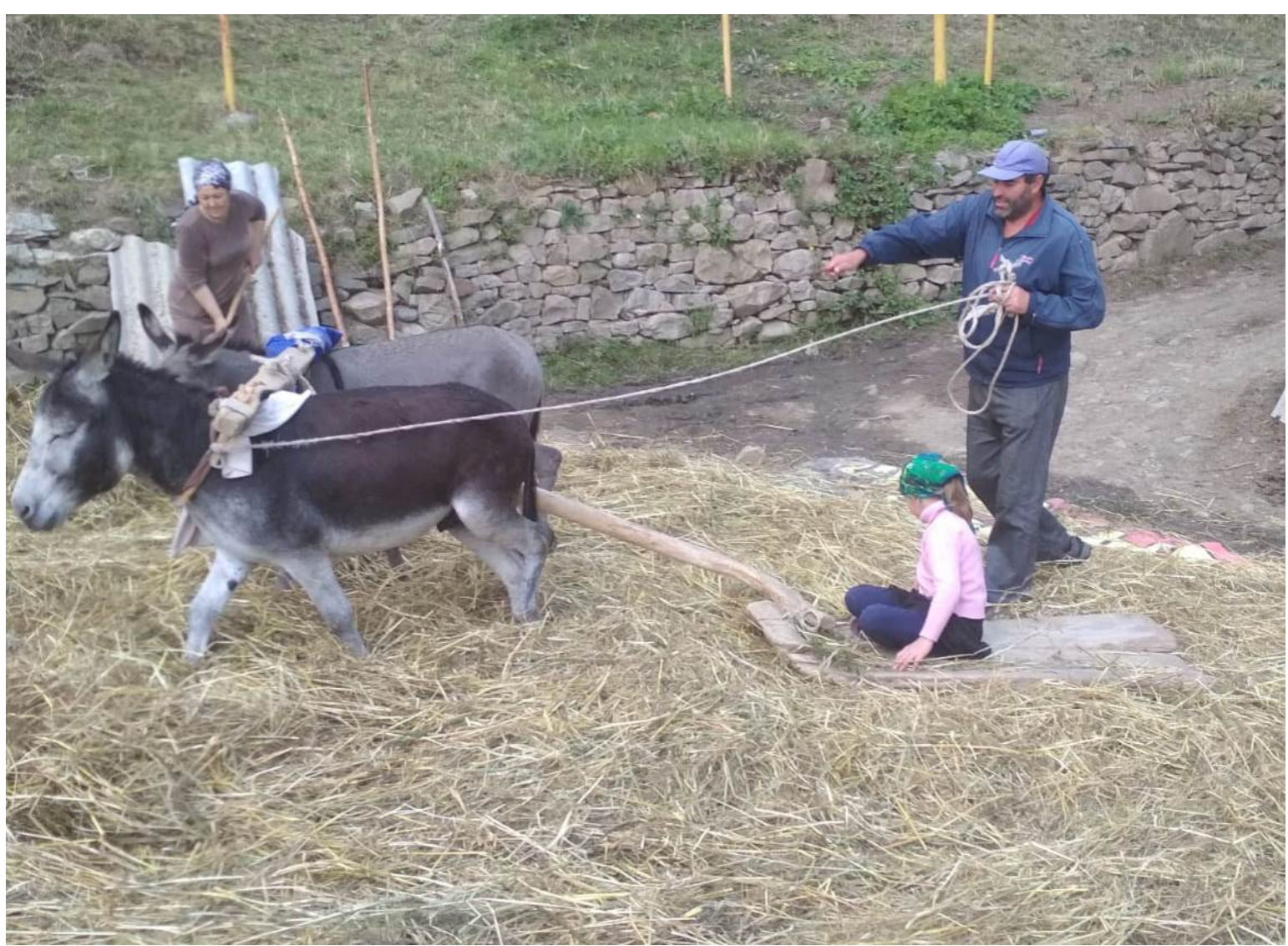

Figure 13. Threshing grain with donkeys and flinted threshing board. Verkhnee Gakvari

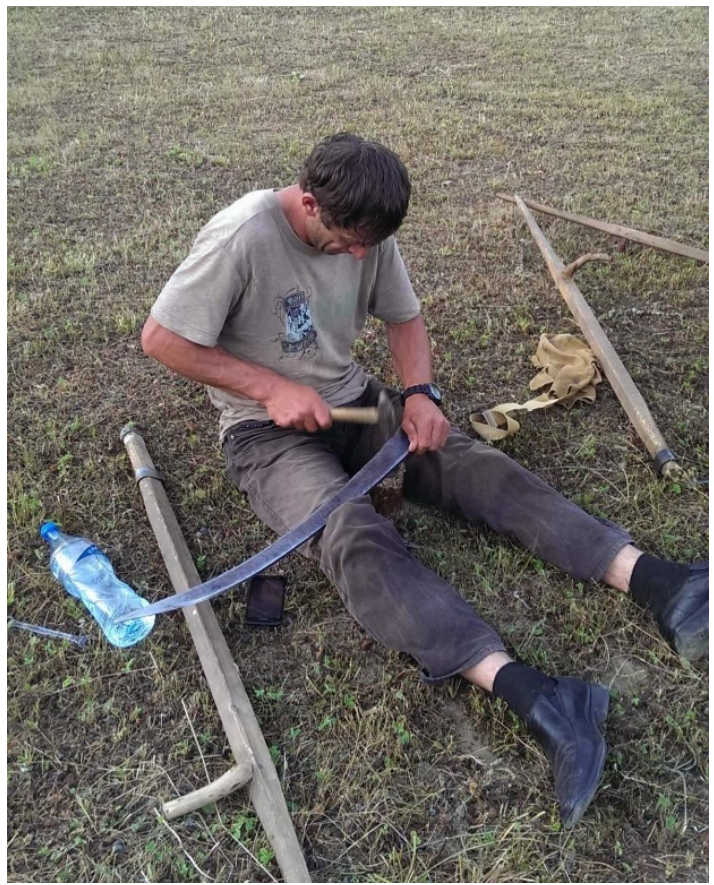

Figure 14. Preparing scythes for cutting hay. Verkhnee Gakvari

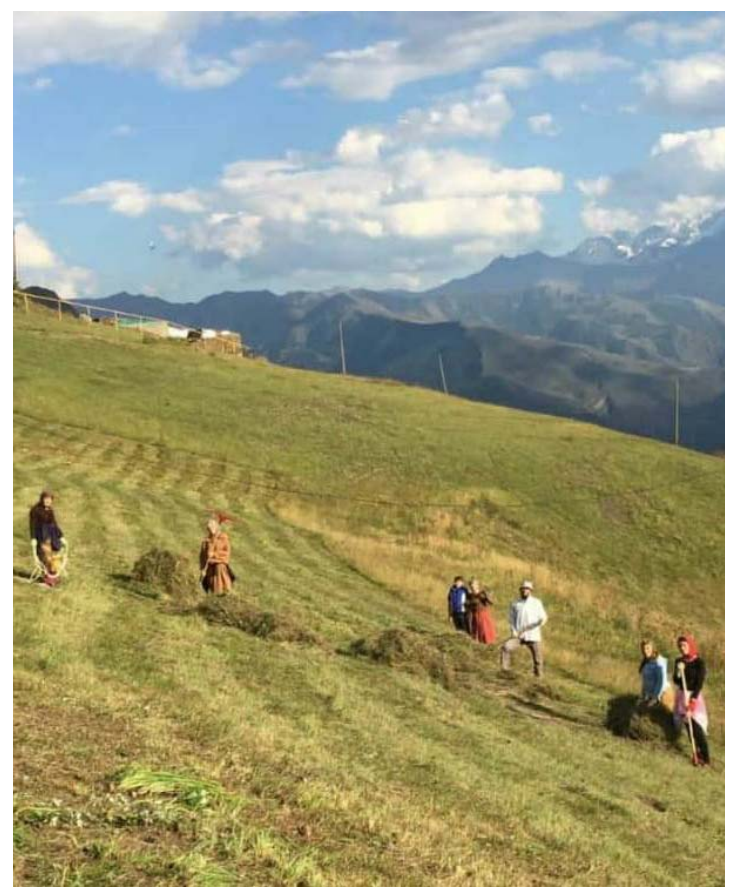

Figure 15. A family cutting hay in late summer.

Verkhnee Gakvari 


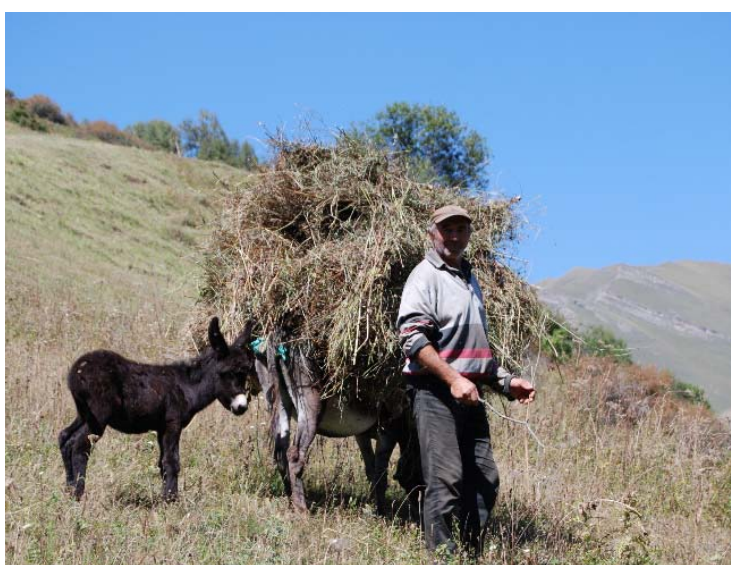

Figure 16. Transporting hay by donkey to family hay loft. Verkhnee Gakvari

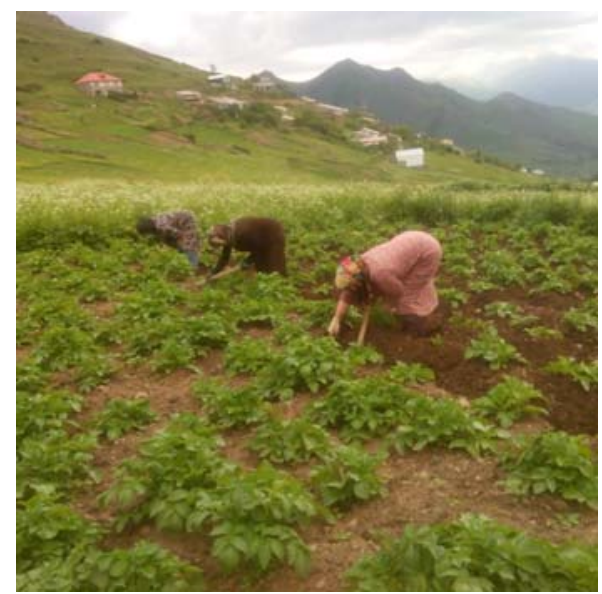

Figure 18. Women tending potato plants

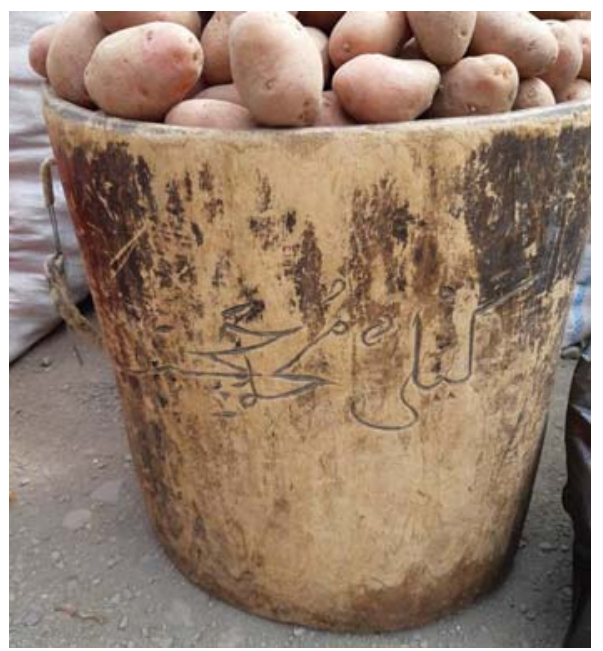

Figure 20. Traditional wooden bucket of local manufacture with Arabic inscription. Selling potatoes in Saturday market in Agvali in spring

Flax was also grown but not to make linen, the dark flax seeds being a much valued-ingredient in urbech.

In the late $19^{\text {th }}$ century salad vegetables such as tomatoes, peppers and cucumbers began to be grown in domestic gardens. Today these, as well as greens like sage, sorrel, parsley, dill and coriander, beet, cabbage, onion and

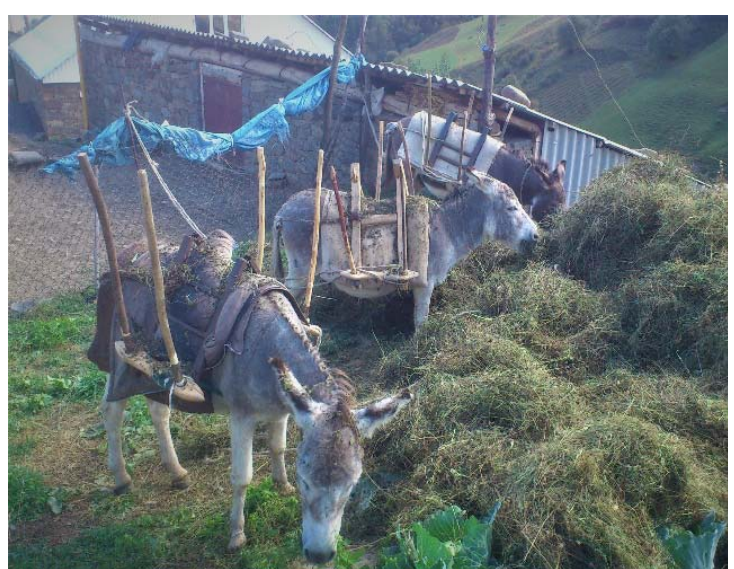

Figure 17. Donkeys feeding on hay. Their wooden saddles are used to transport hay and sheaves of unthreshed grains. Verkhnee Gakvari

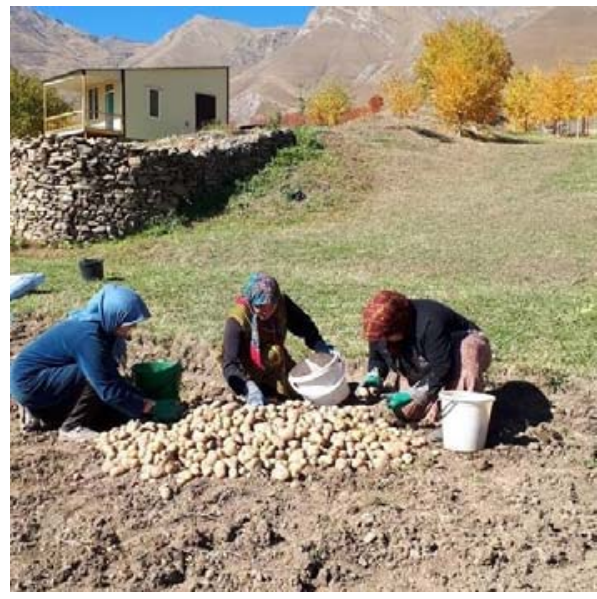

Figure 19. Women harvesting potatoes

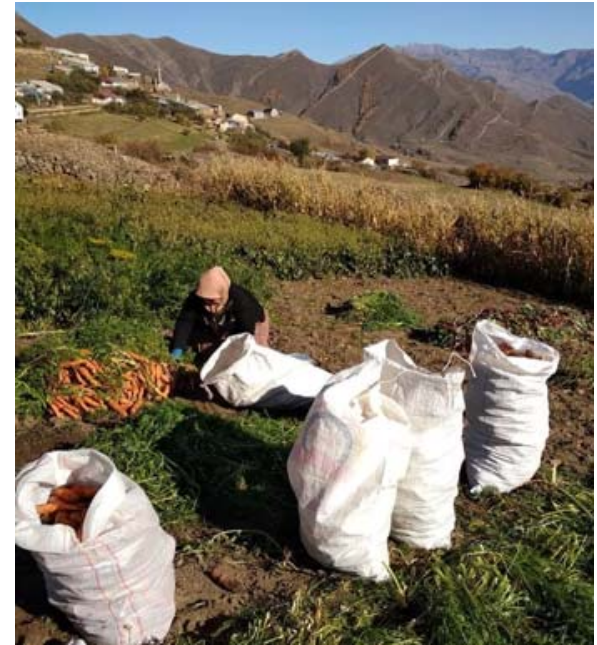

Figure 21. Picking carrot crop in field beside the village. Verkhnee Gakvari

pumpkins, are grown in small domestic plots in soils nourished by manure from adjacent family cattle byres or chicken coups. Wild greens are extensively gathered to be used as salads or ingredients in cooking traditional fried specialities in early spring and summer. 


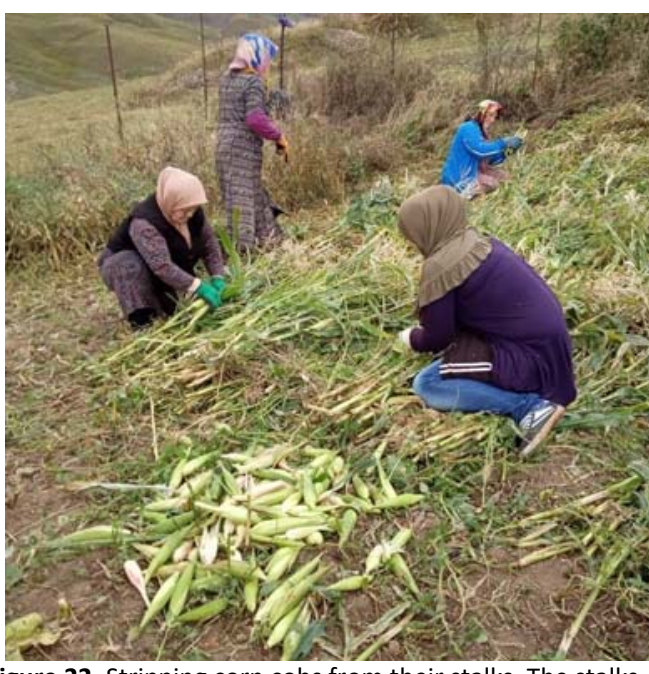

Figure 22. Stripping corn cobs from their stalks. The stalks will be dried and used as winter fodder. Verkhnee Gakvari

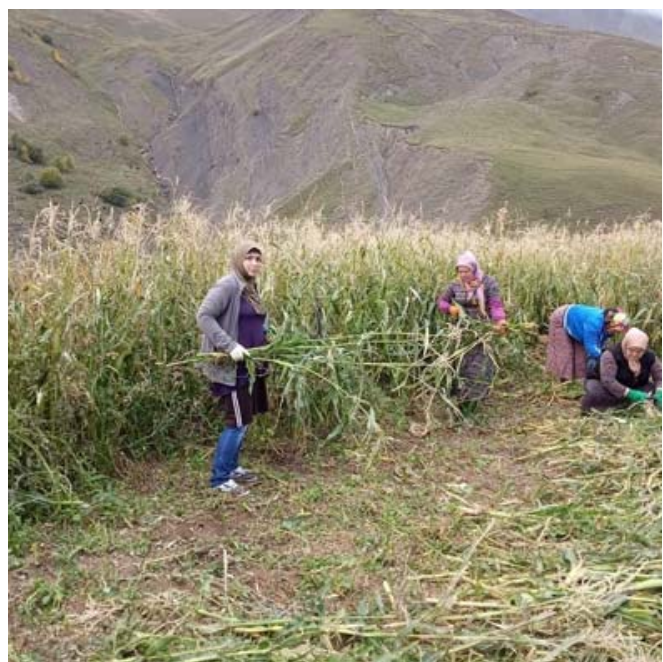

Figure 23. Harvesting corn. Verkhnee Gakvari

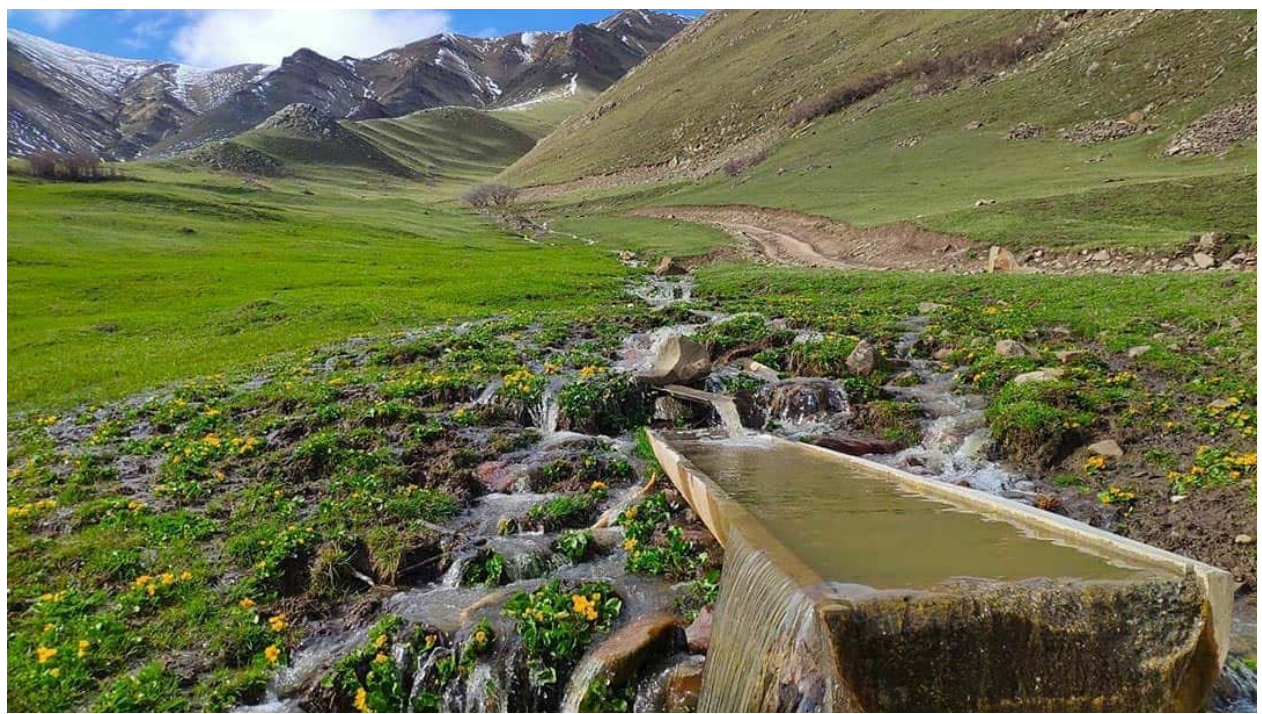

Figure 24. Mountain stream flowing into an animal watering trough in pasture land zone above the village of Verkhnee Gakvari

The preserving of fruits, vegetables and meat was a primary element of the domestic economy and was done when these foodstuffs were at their seasonal peak. Today locals wait until there is a glut in the national market for tomatoes, peppers and aubergines when they can be bought in bulk at the regional weekly markets in Agvali cheaply. Some are processed and bottled, while some are cut up and packed in domestic freezers. Local meat which was traditionally cut up or made into sausages and air dried in winter is nowadays also placed in domestic freezers after slaughtering. The community thus ensures itself of low cost, nutritious organic foods all year round.

\section{Community forest zone}

Embracing and adjacent to or at a slightly higher elevation to all these north-central Andiiskoe Koisu headwaters communities within their surrounding croplands is a natural forest zone usually dominated by Sosnowskiy pine (also known as Pinus kochiana or Sosna kokha) endemic and specific to this region of mountain Dagestan [31], which provided easily accessible timber for building and the manufacturing of utensils and tools as well as fuel for cooking and heating. Further upstream the forests of the Andiiskoe Koisu are of birch or mixed birch and pine [32].

Here it is important to stress to what degree the common highland culture of this region is linked to the local plant world. Unlike most communities of traditional Dagestan, which have habitually used earthenware pottery for millennia, those of the upper Andiiskoe Koisu region are characterised by a remarkably non-ceramic culture. Ceramics were not made locally, although it is reported that those from the traditional pottery making centre of Balkhar in the Akushiinskiy District of east central Dagestan were popularly traded items.

Traditional settlement sites along the Andiiskoe Koisu are accordingly remarkable for the absence of ceramic sherds, so useful to archaeologists and ethnologists for dating and cultural attributions. Instead many forms of traditional containers, plates bowls, spoons, kneading troughs, saddles etc. were locally made of wood (often decoratively carved) [33]. Even today in the principal regional weekly market held on Saturdays in Agvali, the district administrative centre, potatoes in season are presented in fine-walled cylindrical wooden buckets, some still inscribed in Arabic script. Local plants also provided materials for utilitarian basketry items, such as baskets for carrying produce, mountain backpacks and saddle baskets for donkeys. These were often produced domestically. Certain items of metal made in other places of Dagestan which specialise in metalwork were also part of the traditional repertoire of housewares. Metal pitchers and large jugs for carrying water and large cauldrons and frying 
pans were standard items in every household in the region. Expensive metal utensils were purchased at the bazaars of Khunzakh, Agvali, Botlikh, Buynaksk and other places. Today these items have largely been replaced by similar forms industrially produced of plastic or metal.

A blacksmith worked in most larger settlements, producing a range of practical iron items used in agriculture such as ploughs, hoes, picks and rakes, as well as fittings, tools and utensils used for a multitude of building and domestic purposes.

Precious domestic supplies of grains, seed and dried goods are housed in carefully constructed wooden storage structures (in Russian generally called ambar - but with variants in each of the local indigenous languages) of interlocking evenly adzed timbers, installed outdoors but immediately adjacent to the stone built dwellings. They provide a secure rodent-free and dry storage environment. As in other regions of mountain Dagestan, grain was also stored indoors in large wooden grain bins which were a major decorative feature of household interiors. Wood for

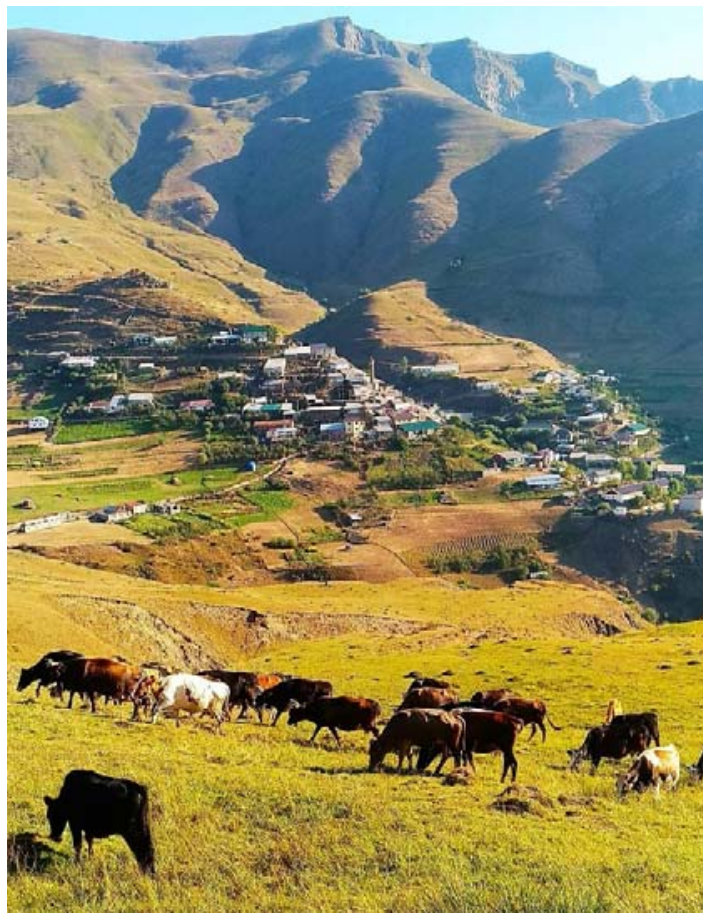

Figure 25. Cattle grazing on periphery of central cropland zone of Verkhnee Gakvari

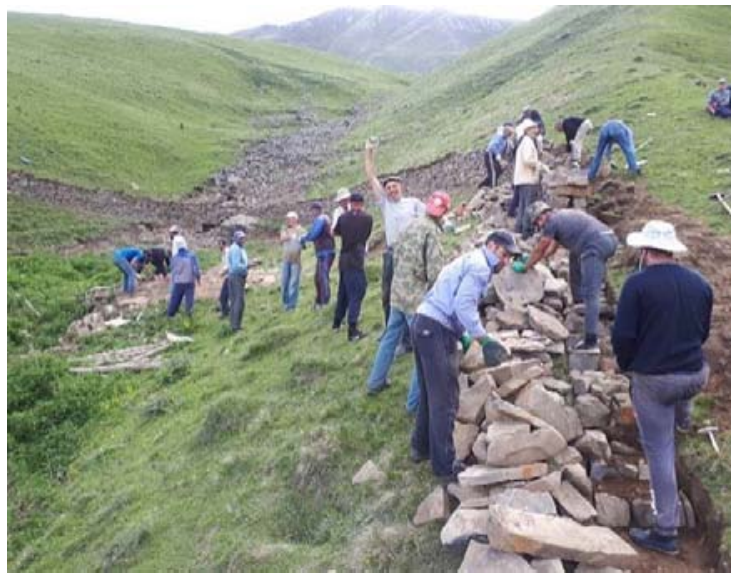

Figure 27. Villagers collaborating to build a rough stone wall to corral cattle building was cut in the forest by itinerant brigades of specialists who visited the settlements each year and crafted the various timbers used in the local vernacular traditions. The massive dimensions of some of the pine beams in older buildings are testimony to the scale of the conifers that once grew in these forests. They are potentially important sources of dendrochronological and climatic data.

The neighbouring forests and the vegetation on their verges provided an abundance of wild edible seeds, cones, nuts and fruits. The acidic soils of the area supported a range of plants producing wild berries. Some were used for teas as were wild herbs such as oregano, thyme and mint. Clear nutritious birch sap was also collected.

\section{Pasture zones}

Stockbreeding of sheep and cattle was a fundamental component of traditional village subsistence throughout the alpine communities of the Andiiskoe Koisu (Fig. 25-28).

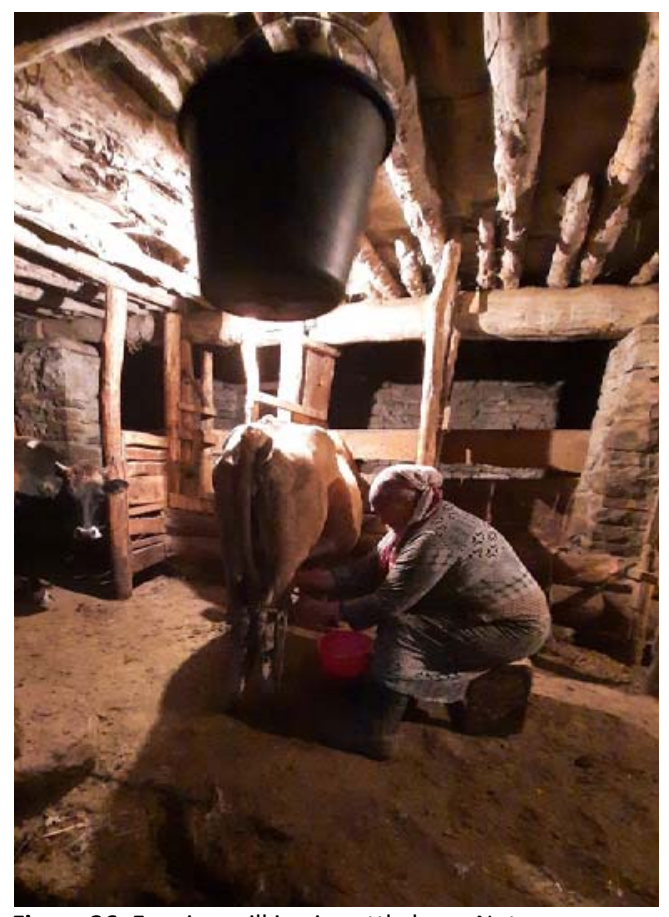

Figure 26. Evening milking in cattle byre. Note construction formed by rough trunks from adjacent forest

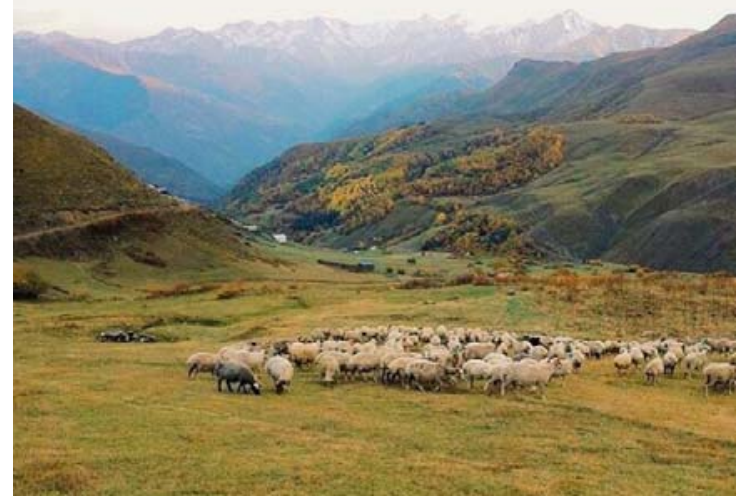

Figure 28. Sheep grazing in pasture lands above the central cropland zone of Verkhnee Gakvari 
The small cattle of the highlands exemplify the results of the productive interplay between man and nature in these mountains of Dagestan. Originally domesticated from the mighty wild auroch, by the Bronze Age taurine cattle across their domesticated range had been selected for certain desirable traits, including a much smaller size [34-38]. Hardy small short-horned breeds were adapted to the climate and natural food resources of the high mountains of Dagestan. They also possessed a range of positive behavioral features. Their small size meant that they had a correspondingly small environmental footprint. One of their most noteworthy aspects is their docility and minimal need for herding by humans. Without any prior training, they may be let out of their byres in the morning and find their own way along village verges and mountain sides procuring sufficient food in the myriad small clumps of native vegetation. In the evening they gradually tread their way back to their byres. This is generally how milch cows are pastured throughout high mountain Dagestan but in villages such Verkhnee Gakvari steers which are bred for meat may be herded daily to more distant pastures and then gathered back in the late afternoon without any supervision during the day. In previous times, when natural predators such as wolves and bears were a real threat, a constant herder presence was required but this not really an issue today for livestock except for sheep grazing near forests at high altitude.

The small stature of these cattle meant that were very manageable, not demanding large quantities of stored winter fodder or requiring large byres. Their milk is rich and they are good milkers relative to their size and a single steer would provide a convenient amount of meat for a family. The mountain environment was in itself a blessing as it allowed air-dried meat and sausages to be produced (seasoned with wild herbs such as mint, oregano and thyme), which was the form in which meat was kept until the introduction of modern electric freezers. Fresh milk was generally not consumed but made into airan, sour cream, tvorog or as cheese, which was eaten fresh or stored in brine to be consumed throughout the year. Cheese and butter were exchanged for grain. Cattle hides were traditionally used for boots. Cattle manure was used as an annual fertilizer in both cropland and domestic vegetable plots. It was also added to make soils with a high clay content (and therefore hard to plough when dry) easier to plough and till.

Small sturdy steers were used to draw the plough and the low two-wheeled mountain carts used to carry heavy materials such as rocks and wooden beams for the construction of buildings.

Flocks of the local breed of fat-tailed Dagestan mountain sheep [39] are pastured on the rich alpine mountain meadows and open grassy mountain slopes in summer. Their large fatty tails (kurdiouk) are air dried as a nutritious high protein mountain delicacy, eaten raw and sliced thinly like a cheese or fried in various dishes. Large flocks are driven in autumn down to the lowlands behind the coast where there are extensive pastures in the hands of families originating from the regions of the upper Andiiskoe Koisu and re-settled there in the Soviet period. In late spring they return again to their mountain pastures. An impressive and majestic sight is an oncoming droving procession, sheep and goats filling the roadway with the flock led by the shepherd on a horse slung with his gear and preceded hieratically by a group of mature goats with magnificent dark vertically growing twisted horns like tall ritual mitres. Sheep dogs with hair the colour of the sheep are in constant movement among the flock. A small group of donkeys with supplies or carrying newly born lambs accompanies them. Goats are raised for their meat.

\section{Alpine pasture and wilderness zones}

At higher alpine altitudinal zones above the main settlements are rich natural grassy pasture lands, while higher and more inaccessible are the rocky terrains and peaks which are the natural habitat of the large indigenous mammals, the Dagestan tur, the bezoar goat and chamois (roe deer were found at lower altitudes). Tur were formerly hunted for their meat, but nowadays are hunted purely as a regulated trophy sport by outsiders using rifles. Firearms have been known in the northern Caucasus since the $16^{\text {th }}$ century but became widespread only in the $18^{\text {th }}$ century. Bows and arrows were traditionally used for hunting tur and deer and for village defense well into the $19^{\text {th }}$ century in some such remote areas of Dagestan [40]. Pecked and incised images of tur and deer found on the stonework of traditional masonry structures in the headwaters communities of the Andiiskoe Koisu are witness to the special societal connections with the earlier pursuit of these species of wild game. Wild boars were also hunted in the forest as were birds, mainly partridges and ulars, living on alpine meadows.

\section{River tributary gorge zone}

In the typical altitudinal functional zonation of these communities, the relatively even expanses of flat crop lands around the core settlement change to a much steeper gradient as the axial tributary river cuts a narrow defile downwards to eventually flow into the Andiiskoe Koisu below. Horizontal water mills were often located where the tributary river takes a more rapid course in this zone. Many communities had more than one mill (they had been a standard feature of mountainous life of the core areas of Islamic world since the beginning of the first millennium CE). Although they were largely abandoned in mountain Dagestan following the massive introduction of industrially milled flours from the central grain belts of the USSR from the 1960s onwards and the introduction of diesel powered mills, a number continue to be serve the headwaters region of the Andiiskoe Koisu [41]. With their clean power source, they are used to grind wheat and corn into flour as needed and to grind urbech (a nutritious paste or butter made of ground nuts, kernels and seeds apricots, linseed, hazel nuts, walnuts, etc.) which is an energy-sustaining culinary icon of Dagestan mountain life). Fresh stone-ground flour has a more favoured texture than modern industrially-produced flours and the miller has complete control over the quality of his product.

The steep open slopes of the tributary gorge zones serve as rangelands for both cattle and sheep.

\section{River junction zone}

The lowest community territorial zone is where its axial tributary river meets the main course of the Koisu. Here terraced fields with carefully built retaining walls are constructed where orchards of fruits and vegetables may be grown at the higher riverine temperatures at the lower altitude of $1,000 \mathrm{~m}$ near the river and where there is the possibility of irrigation. The Gavarinka River valley is unusual in that its waters reach the Koisu through a waterfall and therefore is no cultivated land there. 


\section{Transportation infrastructure}

Each community territorial zone is linked to its immediate neighbours by a system of well-engineered and maintained trails passable on foot or by donkey along the shared elevation levels of the settlements themselves, reducing the distance and time required to travel between them. Only since roads serving automobiles were built along the edge of the Andiiskoe Koisu and then along the tributary valleys have these highland trails been superseded, considerably extending the distance of travel between settlements in comparison to the former upland direct cross country routes.

Introduced from northeast Africa into the Near and Middle East some 7,000 years ago, donkeys became the principal form of animal transport and an essential component of the agricultural life of these high altitude Caucasus communities, whose networks of mountain trails, often constructed of narrow stone slabs along near vertical cliff walls, was only passable by man or by donkey. Robust and easily cared for, they were both ridden and carried all manner of goods and agricultural supplies throughout each village territory and also onto regional markets. They were also used to thresh grain, hauling flint embedded threshing boards over the dry sheaves of grain. As new all-weather roads are now being constructed to most settlements, donkeys are no longer needed as much as before and their numbers have decreased sharply, although they are still used to carry burdens from some agricultural locations which are difficult to reach by motor vehicle.

The magnificent mountain horses of the Caucasus were more of a status animal in this highland region, requiring much more care than the donkey (e.g. donkeys do not require metal shoes). Horses, however, are essential in herding the large flocks of sheep and goats along the droving routes from alpine to lowland pastures at the beginning and end of winter. They are also occasionally used to pull a plough.

\section{Russian Administration}

The millennia old system of mountain communities living in synergy and harmony with the natural environment was still functioning when encountered by the Russian Tsarist administration when it prevailed in 1858-1859 over the Muslim forces of Imam Shamil and the Imamate of the Dagestan and Chechnya lands which he led in resistance against occupation.

The Russian colonisers became well aware of geography and demography of the headwaters territory of the Andiiskoe Koisu as it was along this valley that Imam Shamil's forces first attacked Russian forces in Georgia which had ceded to Russia in 1801 and it was along this route that the conquering Russian troops later proceeded to occupy the valley communities of the Koisu. Imam Shamil's grandfather, Denga, was a Chamalal, either from Gakvari or Gigatli. Five of the Imam's naibs (deputies) were from Gakvari and many Gakvarins fought in his campaigns.

The initial Tsarist administrative structure reflected the ethnic realities of the region in the form of the Andiiskiy Okrug which was formed as part of the Dagestan oblast in 1861. The Okrug covered the whole territory of the valley of the Andiiskoe Koisu south from the mountain passes leading from Chechnya into Dagestan and incorporated the ethno-linguistic enclaves of the region as administrative subdivisions. After the socialist revolution in 1921, the Dagestan ASSR was formed and continued to incorporate the Andiiskiy Okrug. In 1928, the Tsumadinskiy (kanton) district administration was formed and included all Chamalal villages with the exception of those that belonged to Chechnya. Starting with the All-Union census of 1939, the Chamalals were included among the Avars. This Soviet ethnic reconceptualising of the many disparate local ethno-linguistic identities into a single grouping as Avars neither reflects historical of ethnographic reality nor the locals inhabitants' perception of themselves.

\section{Verkhnee Gakvari}

This case study of a traditional socio-ecological production landscape in highland Dagestan examines one characteristic agro-pastoral community in the Andiiskoe Koisu headwaters region, Verkhnee Gakvari, and the impressive contribution structured systems of public education and communally shared beliefs have made to developing and sustaining viable socio-ecological management in successive phases of its long history.

Verkhnee (Upper) Gakvari is the uppermost of two villages (the other is Nizhnee (Lower) Gakvari) which occupy the valley of the Gakvarinka River which is a leftbank tributary of the Andiiskoe Koisu. The village itself lies at approximately $1,800 \mathrm{~m}$ above sea level (coordinates $42^{\circ} 32^{\prime} 53^{\prime \prime} \mathrm{N}, 46^{\circ} 01^{\prime} 59^{\prime \prime} \mathrm{E}$ ) and has some 400 permanent residents. Its stone masonry dwellings are tiered one above the other with a mosque on a rocky outcrop at the lower levels of a long, open, alluvially eroded glacial valley with deep, clayey glacial soils backed on the west by the high peaks of the Snegovoy Range bordering the Chechen Republic and the Republic of Georgia.

Open arable land and pastures surround the village with birch forests on the slopes to the immediate south. The river flows along one side of the village in a valley which becomes increasingly steeper as it descends to flow into the Andiiskoe Koisu through and beyond the village of Nizhnee Gakvari. The vestiges of peripheral khutora remain as witness to their earlier important function in village agricultural life.

The inhabitants of Verkhnee and neighbouring Nizhnee Gakvari are a separate ethnic component (Gakvarins) of the Chamalal Andian subgroup of the AvarAndo-Tsez group of the peoples of Dagestan. Their selfdesignation is chamalal. The Chamalal language belongs to the Andian subgroup of the Avar-Ando-Tsez (Avar-AndoDido) group of the Nakh-Dagestan branch of the Northeast Caucasian family of languages. It remains an unwritten language. Chamalal has three distinct dialects: Gadiri (Gachitl-Kvankhi), Gakvari (Agvali-Richaganik-TsumadaUrukh), and Gigatl (Gigatli). Chamalal people refer to their language as Chamalaldub mitss (lit. "the language of the Chamalal"). The exact meaning of the word "Chamalal" is obscure, but it is probably an Avar loanword meaning 'dried apricot' (this tree is endemic to the slopes of the Andiiskoe Koisu basin) [42].

There are no precise figures of the number of Chamalal speakers, since they are often misclassified as "Avar". Estimates range from some 5,000 to 12,000. The UNESCO Atlas of the World's Languages in Danger [43] classifies the language as "definitely endangered" (the number of young Chamalal speakers is decreasing under the influence of the rural exodus and life in a society where Russian and Avar are the dominant languages).

The Andic family is the group of Dagestanian languages that has been least studied and is particularly poorly represented in terms of audiovisual documentation. The first to pay attention to Chamalal as an independent 
linguistic group were R. Erckert and A. Dirr in the late $19^{\text {th }}$ and early $20^{\text {th }}$ century $[44 ; 45]$. More systematic research commenced only after World War II (A. Bokarev and Z. Magomedbekova) [46; 47]. In recent years Kristian Roncero of the Department of Linquistics and Cultural Evolution, Max Planck Institute of Evolutionary Anthropology in Leipzig has been engaged in fieldwork with the Chamalals of Verkhnee and Niznhee Gakvari and has deposited online a range of very informative online audiovisual and interview resources documenting the Chamalal language, history, customs and practices, including ethnobotanics, drying meat, elaboration of urbech, food for winter, gardens, herding, hunting, hunting and fishing, growing flax [48, et al.].

The territory of settlement of the Chamalals stretches for approximately $12 \mathrm{~km}$ along the slopes of the central left bank of the Andiiskoe Koisu along the southern and east-facing slope of the high Snegevoy Ridge. The main upland settlements from north to south are Gigatli, Gadiri, Sasitli, Gigikh, Nizhnee Gakvari, Verkhnee Gakvari, Richaganikh and Tsumada, while at the river level the settlements of Gigatli Urukh, Agvali, Kochali and Tsumada Urukh are located. The neighbors of the Chamalals are: the Godoberins in the north; the Chechens in the west; the Georgians (Republic of Georgia), Avars and Khvarshins in the south and the Tindals and Bagulals in the east.

Part of the Chamalal population also lives in the Shatoisky District of the Chechen Republic. They also live in Soviet-era resettlement villages of the Babayurtovskiy, Kizlyarskiy and Kizilyurtovskiy Districts and in the cities of Makhachkala, Khasavyurt, Buynaksk, Kizilyurt and Kizlyar.

During the Soviet period until 1930, all Chamalal farms were united into partnerships for the joint grazing of cattle. Subsequently, collective farms were created, the formation of which was completed in the first half of 1938 . Over time, they turned into diversified collectives specializing in their traditional community practices of farming, gardening and animal husbandry, mainly due to the possession of land on the lowland plains (which permitted winter sheep grazing). In the 1980s in connection with the transition to a new Perestroika period farming system, all collective farms switched to family contracts, which led to the release of part of the work force who left to work in neighbouring regions and republics, contributing further to the diaspora of the indigenous inhabitants of the Tsumadinskiy district and neighbouring regions which is a characteristic of this population today.

Nowadays, those inhabitants of Verkhnee Gakvari who actually live there can be said to sustain themselves primarily through their traditional subsistence economy. Incomes derived from external sources are limited to government salaries which are earned by school teachers, nurses and a few other state administration employees. There is no public transport between the village and the regional administrative centre of Agvali some $8 \mathrm{~km}$ away, which means that it is not feasible to commute daily to work there (many villagers do not yet have cars). Many natives of the village have left to live and earn incomes in neighbouring Agvali or elsewhere in Dagestan and in other parts of Russia. Some work in seasonal agriculture in the plains in summer and return home for the rest of the year. Many return each year to visit their families for important Muslim, state and school holidays and to help pick and process apricots for drying in season. Many would prefer to live in the home village, if sufficient and sustainable local sources of income could be developed.
Historical Regional Economics

Besides sharing common agro-pastoral life styles, historically communities across the headwaters region were linked together in a broad regional economy. The principal regional market was in Botlikh, which was situated above the Andiiskoe Koisu where it emerges from its north-south orientated upper gorges region and turns towards a more open riverine morphology to the east. This flourishing orchard town was a major commercial centre for the inner Dagestan Caucasus (a local "Paris", as it was described in the late $19^{\text {th }}$ century). Apart from serving as a bazaar for the necessary sale and exchange of locally made goods and services (e.g. of dairy products and grain) it was a major source of desirable goods sourced in Georgia. As Tsarist Russian influence came to dominate Botlikh and adjacent territories, this profitable trade became a major thorn in the side of local Russian administrators who considered it to be an unwelcome competitor to the burgeoning exports of Russian-made industrial wares which were an fundamental driver of Tsarist expansionist policies into the Caucasus (as also into Central Asia at the same period). Russian dictates blockading and prohibiting this trade were strongly resisted locally and fueled the regional resistance to Tsarist expansion which was manifested in the strong regional support for the Islamic Imamate in the first half of the $19^{\text {th }}$ century.

The trade route from the Georgian Transcaucasus passed along well-maintained upper altitude foot and donkey trails connecting the communities of the upper Koisu region and was a structural feature of the economy. In this context, it is important to emphasize that it is a common misconception that the Central Caucasus Range constituted a massive barrier to north-south trade which could only be by-passed via Derbent and the Caspian coastal lowlands trade route or through the Dariel Pass which was to become Russia's strategic Georgian Military Road linking the Transcaucasus to the steppes of southern Russia.

Islam in the upper headwaters region of the Andiiskoe Koisu It appears that Islam penetrated the upper Andiiskoe Koisu valley not by invasion but through a gradual supplanting of Christianity in an upstream direction from the coastal hinterland by Kazi-Kumukh missionaries, supported by the substantial Chamalal community of Gigatli. In 1590 a wellcrafted masonry mosque with fine stone carvings and elaborate massive wooden supports was built in Gidatli and in the $16^{\text {th }}$ century and $17^{\text {th }}$ century similar fine mosques with stone minarets were built in the Bagulali communities of Khvanada and Tlondoda and still function as the spiritual centre of their communities. An impressive mosque with the billowing stepped external mihrab profile characteristic of the region was built in Khushtada in 1588. Listed as a monument of national heritage importance, it was tragically burnt in recent years, leaving only a shell whose magnificent southern wall is in a very unstable condition. Nizhnee Gakvari has an $18^{\text {th }}$ century mosque of finely cut stone masonry.

In the southern Koisu ethnic centre of Tindi, an impressive two story $18^{\text {th }}$ century mosque with minaret and other unique community buildings were built across a defile in the rocky ridge along which the settlement was constructed. The Tindi community was a flourishing centre of Islam and supporter of Imam Shamil at the time of the Imamate. A mosque was built in Khvarshi in 1859. 
Although, as with much of the earlier history of the region, the precise chronology of the adoption of Islam is still to be determined through the dedicated work mainly of local historians, it brought with it an intensity of religious belief which is the region's most ubiquitous and distinctive cultural feature, each community's juma'at being the core of the community's identity and traditional governance. A regional heritage of venerated religious figures within the Sufi tariqah tradition, whose ancestries are often linked to the family of the Prophet Muhammad is reflected in welltended shrines at their grave sites in the cemeteries of many villages. Policies of religious suppression by dominant authorities (including the destruction of community, mosque and personal libraries during the Soviet period) have done little to erode the strength of local adherence to community religious beliefs so long validated by traditional devotional practice and inheritance.

Doctrines fundamental to Islam elucidate a mandatory respect for the environment as a divine creation and benefice to mankind. In a natural landscape of a scale which has always awed and impressed its human inhabitants and which is so evidently the provider of their subsistence, these core Islamic beliefs play a very real and fundamental role in the way the Muslims who constitute the overwhelming majority of the region's peoples view their relationships with the natural world. Consequently, it underpins the importance local inhabitants give to the modern science of ecology and its objectives of the rational and equitable use of natural resources.

This study stresses the role the structured systems of belief shared by the local populations of the headwaters region of the Andiiskoe Koisu played in sustaining a holistic sense of awareness of the intersecting role of man and nature in sustaining the socio-ecological production landscapes which had been shaped by their predecessors over millennia.

Pre-Islamic Belief systems and Shared Communal Mores

Long before Islamic monotheistic values permeated the perceptions of nature of the peoples of this region, there were shared polytheistic belief systems reflecting an awe of the ever-visible and overwhelming dominance of nature in the mountainous landscape and alpine climate in which humankind was dependent and vulnerable to the elemental forces of nature and landscape. In the absence of indigenous written historical sources, Russian and other scholars have researched the oral and other folk traditions of the North Caucasus to better understand these beliefs. There is strong evidence of ancient mountain cults in the region [49]. During a drought, for instance, inhabitants of the villages nearby went to the lake near the Gadari mountain in Chamalal territory and sacrificed a foal, which was bled into the lake, where they also threw the head and recited prayers addressed to the deity so that he would send rain [42].

A thorough understanding of the natural world in which people lived and on which they depended was a fundamental aspect of the subsistence ago-pastoralism of the region and gave rise in each community to the articulation of shared social mores or adat. For more than six millennia from the beginning of human habitation and subsistence in this high mountain zone a complex of customs and belief systems defining human relationships and responsible agricultural practice developed which arose from and responded to the obvious powers of the natural environment.

We can also obtain some sense of the common perceptions relation to the environment through the petroglyphic symbolism frequently found pecked or chased in rock slabs placed in the walls of traditional buildings in the region. While impossible to correctly interpret, there surely can be no doubt that the images of hunting and animals such as deer and tur, abstract symbols such as labyrinths and spirals (and what may have represented cosmic phenomena) often found reflect an interdependence and reliance on the numinous natural world (Fig. 29-34). Here there must be also taken into consideration the links between the illiterate (i.e. without a system of writing) nature of the ethno-linguistic enclaves of the upper Andisskoe Koisu and the use of repeatedly encountered petroglyphic symbols. Just as it has been noted that throughout palaeolithic Europe there was actually a limited but widespread range of abstract symbols used in rock art so the petroglyphs on masonry found in settlements of the Andiiskoe Koisu are also quite restricted and constant in variety of imagery [50]. In 1986, Kotovich attempted to classify and comparatively quantify by form and chronology rock art images of animals (horse, bull, donkey, dog, bezoar goat, mouflon, deer, birds and snakes) found in rock art sites in other parts of mountain Dagestan (Vitturzivalu, Trisanchi and Sanchi) [51].

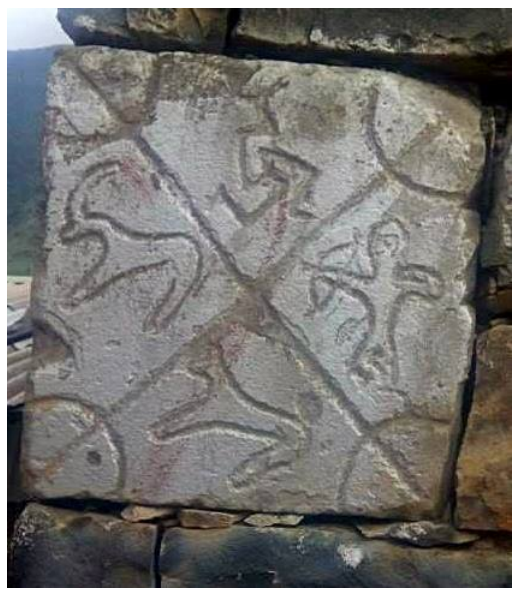

Figure 29. Marble corner stone of building with petroglyph showing hunting mountain tur or bezoar goat with dog and bow and arrow. Avar. Provenance unknown

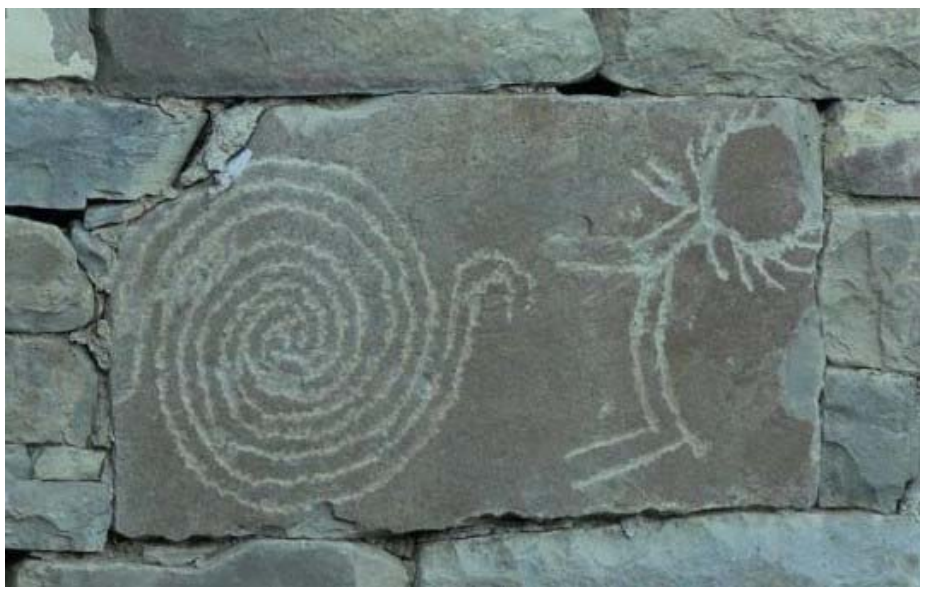

Figure 30. Stone in wall of building in Verkhnee Gakvari with petroglyph depicting a spiral labyrinth symbol and the image of a stag with antlers shaped as though encircling a celestial symbol (sun?) 


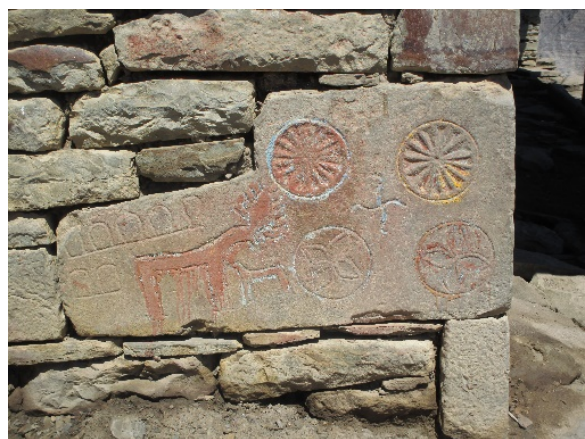

Figure 31. Corner stone with petroglyph of stag, a swastika and a range of circular and arcaded symbols. The coloured overpainting is modern. Chamalal village of Gigatli

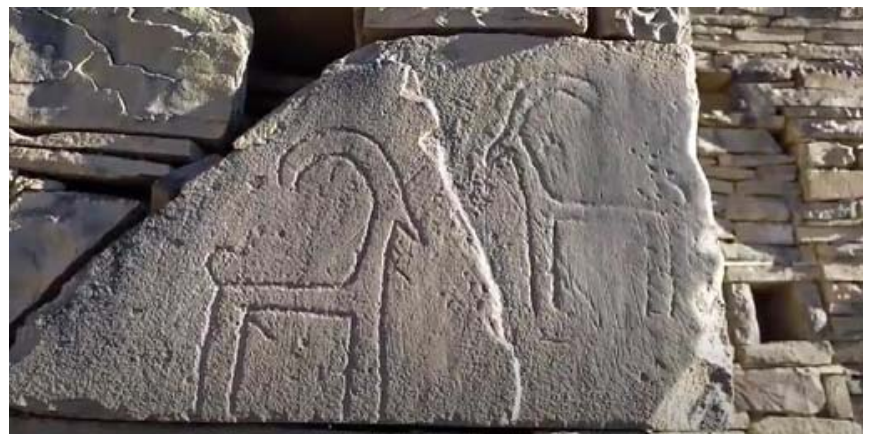

Figure 32. Corner stone with petroglyph of two tur or bezoar goats. Ssuidi (Tsuidi), an abandoned hamlet with excellent masonry work in the eastern part of Chamalal Gakvarin territory

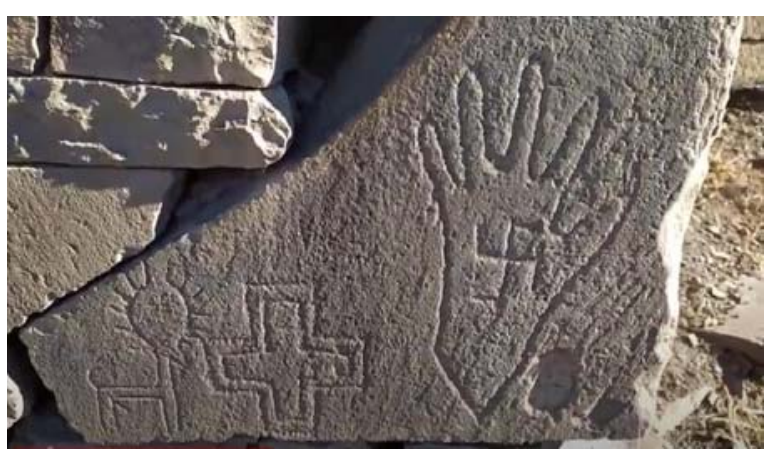

Figure 33. Corner stone with petroglyph of stag of similar iconography to those in Figs. 30, 31 \& 34, a cross symbol and a hand with a swastika. Ssuidi (Tsuidi), Chamalal Gakvarin territory

These enigmatic petroglyphic traditions constituted a sort of early symbolic graphic language expressing specific concepts with consistent forms which retained potency for millennia as indicated by their purposeful placement on buildings up to pre-modern times in the region. This graphic "language" which probably originated in the earliest phases of human settlement in mountain Dagestan continued well into later Islamic times, as evidenced by the depiction of mounted hunters with guns pursuing deer incised into a masonry slab in the entrance gateway of the cemetery of Tlyach in Gidatli, Shamilskiy District. This intersection of earlier beliefs relating to nature with those which superseded them through the adoption of Islam are found in other areas of the Islamic world which have blended their pre-Islamic traditions with Islam. For example, among the Uighur Muslims in north western China or those of Brusho-Shaman culture in the Karakoram mountains of northern Pakistan, nature is regarded as holy in ways not arising from mainstream Islamic philosophies.

Apart from earlier religious beliefs and symbolic ways of representing the universe, there were also strict community rules and understandings about the usage of lands on each village's territory, no matter who the nominal owner. Although we, as yet, have no specific information in this regard for communities in the upper Andiiskoe Koisu, there is good ethnographic information about customs in neighbouring Avar regions where the transfer of land or usage of such was strictly forbidden to any outsiders. Such shared community mores include defining precisely when land should be ploughed and crops harvested. No villagers could infringe these without specific fines and condemnation. All these community mores (adat) worked to strictly maintain and sustain the inherited socioecological landscape as productively and harmoniously as

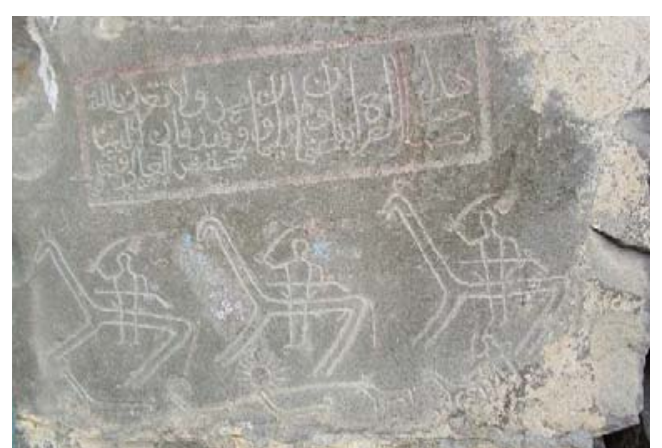

Figure 34. A stone forming part of the gateway to the cemetery of Tlyach, Shamilskiy District

possible [52]. A central dynamic of adat in the formation and maintenance of the cultural landscape of communities like Verkhnee Gakvari, where all members were related, was collaboration amongst households in all activities including those of general benefit, such as construction of roads, trails and stone walls for corralling livestock, etc.

Christianity left no such record of text or depictions relating to the natural world in the region, except in the fine scrolling arabesque frieze which may have drawn on Georgian church architectural decoration over the internal doorway to the $16^{\text {th }}$ century Juma mosque of Gigatli. Evidence of Christianity in the region includes Christian graves of $11^{\text {th }}-14^{\text {th }}$ century in Sasitli and Gakko, historical documentation of a church at Khushtada [53] and Christian artifacts found in the community cemetery in Verkhnee Gakvari.

\section{Islamic Environmental Ethics in the Traditional World} of the Dagestan High Caucasus

Attitudes to the environment were intellectually reinforced and codified by Islamic religious tenets relating to the world of creation and the obligation on all Muslims to respect and properly use nature. Islam articulated a whole range of concepts which are reflected in contemporary scientific narratives and ideologies relating to ecology, environmental ethics and sustainable environmental utilisation [54-66]. These values continue to be embedded in the mindsets of a substantial portion of the Tsumadinskiy population who are practicing Muslims, the scriptural content of the Islamic creed making it compelling to those with a profound religious commitment.

In the process of Islam being consolidated as the principal religion of the headwaters region of the Andiiskoe Koisu, with a mosque and minaret as structures central to 
each community, it is important to emphasize the advanced level of Islamic learning among respected senior Muslim clerics and scholars (ulama) in communities in the region, many of whom possessed significant private libraries or had access to community libraries, and who were able to fully transmit to their students and members of their juma'at the standard doctrines of Islam in Arabic relating to the created world and its sustainable utilization. It was important for parents that their children were educated, as it was considered desirable to be able to read the Quran. Systems of Islamic education common to other parts of the Muslim world were employed in maktabs, mosques and madrasas across the region.

As profound adherents of Islam, the members of each community in the upper Andiiskoe Koisu region perceived it as an independent juma'at with an elected member functioning both as its imam and community leader. The Muslim ummah or community is accordingly the instrument through which Quranic ideals and commands are translated and resonate at the social level.

Islamic environmental ethics are based on legal foundations which Muslims hold to be formulated by God and prescribed in the sources of the Sharia; i.e. Quran, Hadith and fiqh. These legal instructions have been revealed in such a way that the conscience approves and acknowledges them to be correct. Thus the law itself becomes a part of human conscience, thereby guaranteeing its application and its success. According to Islam, the environment is God's creation and to protect it is to preserve its values as a sign of the Creator. According to a tradition, Prophet Muhammad taught that "all creatures are like a family of God; and He loves the most those who are the most beneficent to His family".

Islamic environmental ethics are moral principles which define what is good for society, based on the concept that all human relationships are established on justice ('adl) and equity (ihsan): "Surely Allah enjoins justice, kindness and the doing of good to kith and kin, and forbids all that is shameful, evil and oppressive" (Sura AnNahl 16:90). According to this Quranic revelation, human relationships should be just and therefore human relationships with nature should also be just. The Quran says, "And the earth, He has set it for living creatures." Humanity is not the only community of living beings in the world, therefore all living creatures are worthy of protection and kind treatment. Man, animals and plants all depend on earth.

In Islamic philosophy, man accepted nature as a trust (amana) for his moral struggle. God expressed his confidence in the ability of man to preserve nature as his responsibility. In the Quranic theology of creation God created this cosmos which humans are guardians of for a limited period of time. Man is further distinguished as the only creature in this universe endowed with intellect. The Quran says, "Man is gifted with intellect and the power of conceptualization". Thus man should utilize his power of intellect for preserving and protecting his fellow creatures. Islam blames those who do not employ their intellectual faculties of thinking, reasoning and meditating, "We created many of the jinn and mankind for hell. They have hearts they do not understand with; they have eyes they do not see with; and they have ears they do not hear with. Such people are like cattle - no, they are even more misguided. Such are the heedless" (Sura Al-Araf 7:179). After this life Almighty Allah will audit and judge individuals for using or misusing the world. All acts performed in accordance with the Islamic world-view and when done intentionally for the sake of God are considered and rewarded as acts of worship.

"The Lord has created and balanced all things and has fixed their destinies and guided them" (Sura Al Ala 87:2-3). The foundation for environmental protection in Islam mirrors that of modern concerns for preservation of biological diversity and ecological relationships and is based on the principle that all aspects of the natural world were created with functions carefully determined and meticulously balanced by God. Another Quranic verse says, "There is no moving creature on earth but its sustenance depends on God: He knows the time and place of its temporary deposit: all is in a clear record".

Islamic values are considered unalterably accurate and Muslims are obliged to obey what God has ordered. The natural world thus is brought under moral control.

Islam permits the utilization of the natural environment but this should not involve unnecessary extravagance, destruction or wastage. The Quran says, "O Children of Adam, dress yourself properly whenever you are at worship: and eat and drink but do not be wasteful: God does not like wasteful people" (Sura Al-Araf 7: 31).

The environment is not in the service of the present generation alone. Rather, it is the gift of God to all ages, past, present and future. The Quran says, "Cheat not in maintaining the balance. Establish just measure and do not fall short in maintaining the balance".

The interaction between the creatures and the environment in their service to one another represents a symbolic scenario supporting the doctrinal belief in Islam that it was God who created this interactive system and that all of its elements should be nurtured and maintained. The Quranic verse says, "There is no moving creature on earth but its sustenance depends on God: He knows the time and place of its temporary deposit: all is in a clear record".

The relationship between human beings and their environment includes more than subjugation and utilization. Our relationship to nature also includes meditation, contemplation and enjoyment of its beauties. The component parts of nature are entities in continuous praise of their Creator. The beauty of nature is an accolade for Allah. Man's dependence on earth is not only physical and biological but spiritual and aesthetic as well. The Quran says, "He who has made for you the earth like a carpet spread out; has enabled you to go about there in by roads (and channels), and has sent down water from the sky".

Islam has enjoined upon Muslims a relationship of rights over animals. All living things are partners to man in existence and submission to God, thus man must be merciful toward animals and strive to ensure the preservation of different species. Muslims are strongly enjoined to treat animals with compassion and not to abuse or kill them except for food, the latter permission having to be carried out in accordance with the Sharia. The Prophet Muhammad said, "If without good reason anyone kills a sparrow, or a creature lesser than that even, the living creature will put his complaint to God on the Day of Judgement", saying, "So-and-so killed me for no purpose". To be considerate with animals and plants even during war is the teaching of Islam. The Prophet's companion, Abu Bakar Siddiq said, "Do not cut down trees and do not kill animals except for food". Islam thus prohibits the cutting or destruction of trees and plants and encourages people to plant, protect and increase plants for the great spiritual 
reward associated with this. According to Islam plants are creatures that praise God and are worthy of respect. Tree planting is advised to Muslims in the prophetic hadith on the authority of Anas bin Malik, "There is none amongst the Muslims who plants a tree or sows seeds, and then a bird, or a person or an animal eats from it, but is regarded as a charitable gift for him".

In another hadith the Prophet said, "If the Hour starts to happen and in the hand of one of you is a palm shoot or seedling; then if he is able to plant it before the Hour happens, let him plant it". This explains Islam's concern that the earth be green and full of produce until the end of man's life on earth. It encapsulates the principles of Islamic environmental ethics. Even when all hope is lost, planting should continue for planting is good in itself. The planting of the palm shoot continues the process of development and will sustain life even if one does not anticipate any benefit from it.

Similarly, Man's dependence on earth is not only physical and biological but spiritual and it is necessary to maintain and not transgress the balance of the Universe created by God, since "everything is measured by him". The Quran says, "He created man and taught him clear expression. The sun and the moon both run with precision. The stars and the trees bow down in prostration. He erected heaven and established the balance, so that you would not transgress the balance. Give just weight do not skimp the balance. He laid out the earth for all living creatures". Another verse says, "Do not mischief in earth after it hath been set in order". Thus concepts central to modern environmental conservation have been commonly practiced by Muslims for centuries.

Wastage is prohibited in Islam. Earth is of the Lord and is the inheritance of the righteous. Man is invited to enjoy all it has to offer for the comfort and enjoyment of man, to eat and drink but not to commit waste. Only humans need the guidance of a scripture in this regard, as only the human species has free will; all other species do their God-given tasks automatically. There is a hadith which says that the Prophet passed by his companion Sa'd, who was washing for prayer, and said, "What is this wastage, 0 Sa'd?". "Is there wastage even in washing for prayer?" asked Sa'd and he said, "Yes, even if you are by a flowing river!".

Environmental ethics has played pivotal role in shaping environmental policy in Muslim countries throughout history. The concept of himil (protection of certain zones) and rima (involving the ruler's or the government's protection of specific unused areas) are good examples of how Islamic rule established infrastructural systems that offered protection for nature. The protected area system had essentially the same minimum requirements required by modern conservation standards, which made Muslims very nature friendly long before this was practiced in the west. The concept of himil can still be seen in many Muslim countries, such as Saudi Arabia, where it is practiced by the government to protect wildlife.

The preservation of water for the nourishment of humankind, animal life, bird life and vegetation is a practice that gains Allah's pleasure. The Quran says, "Then let man look at his food, (and how We provide it); for that We pour forth water in abundance; and We split the earth in fragments; and produce therein corn; and grapes and nutritious plants; and olives and dates; and enclosed gardens, dense with lofty trees; and fruits and fodder; for use and convenience for you and your cattle" (Sura Abasa 80:24-32).

The Quran and the hadith place a number of obligations and responsibilities to conserve existing water supplies in the best possible way, to prevent any activity that might lead to the pollution of water resources or spoil the purity and characteristics of the water, and never to adopt an extravagant or irresponsible attitude in the consumption of water. It is God's will that all living beings on earth depend for their existence on water: "...We made from water every living thing..." (Sura Al Anbya 21:30). This has provided the religious justification for the protection of water resources. Water is seen by Quran as a sacred cleaning agent, tahur, used in ablutions in preparation for prayer (wudu), as well as for variety of other religious actions in Islam. It gives life to earth and is used to clean man physically and spiritually. Human health, agriculture, forests, and aquatic life, in fact the whole ecosystem is affected by problems associated with water. Islam forbids wasting water and using it without benefit.

It was this basis of codified and shared community attitudes to the environment and its conservation as taught and reinforced in lessons and dialogues in local mosques over centuries that provided the foundation for the remarkable use in the Chamalal settlement of Verkhnee Gakvari of the its school in the Soviet and post-Soviet systems of public school education as the platform for a robust community-wide system of care for the environment, which has become entrenched in the shared value system of the people of Verkhnee Gakvari.

\section{Soviet Public School Education in Verkhnee Gakvari}

As the political situation in the new USSR stabilised in the 1920s following bitter regional conflict following the October 1917 Bolshevik revolution, communities and traditional crafts and industries and agricultural systems throughout Dagestan were regrouped into standard state systems and specialists were sent from more central European areas of the USSR to establish schools, clinics and core administrative functions.

From the first days of the existence of Soviet power in Dagestan, the government of the republic paid serious attention to the need to raise the general educational and cultural level of the working people. Public education in the republic experienced great difficulties as there were not enough teachers and funds to open new schools and there was no formalised educational and material base except that of traditional Islamic education in maktabs, madrasas and mosques [67-68] (Fig. 35, 36). Arabic was also used as a language of business communication and public administration and in correspondence. Its role was very significant, particularly given the fact that the indigenous languages of peoples in the upper reaches of the Andiiskoe Koisu were unwritten. The role of the Arabic language as an accepted language of instruction, religious culture, and also as a means of communication is difficult to overestimate.

The problem of spreading literacy in Russian Dagestan took a long time to be resolved. One contentious issue in traditional communities for the new atheist administration was the transition from writing and reading Arabic script to the universal comprehension and use of Cyrillic in Russian in all writings and printings [69-72]. Besides overt power politics, the central Soviet administration had to use more covert means to strengthen its regime, with its principal aim of transforming the social order and the psychology of the local populace. 
The new educational system was a tool to this end. As the Chamalals were considered too few to have their own written language, Avar was initially used for schooling. During the years of the republic's first five-year plan (19281933), it was intended to introduce universal compulsory primary education throughout Dagestan and to completely eliminate illiteracy among highland dwellers aged 16 to 25 years. It was thus in 1932-1933 that the first schools appeared in the mountainous regions of Dagestan.

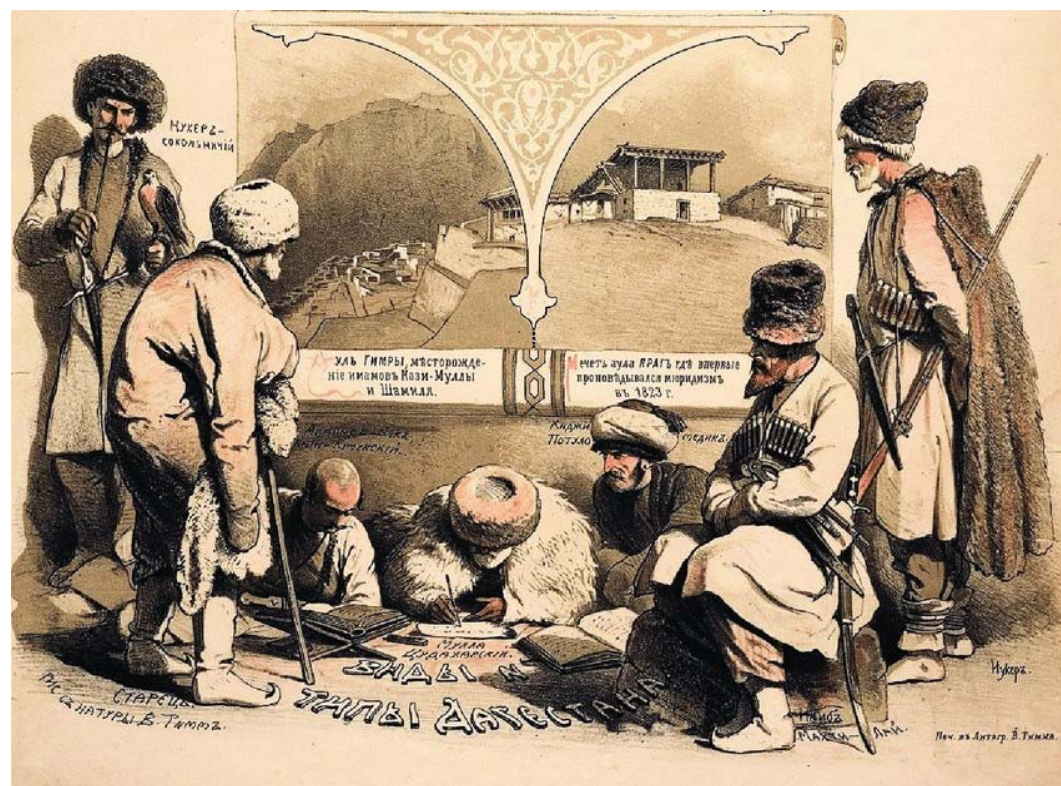

Figure 35. Lithograph by Baltic-German Painter, Vasili Fedrovich Timm (1820-1895), of a group of. Imam Shamil's compatriots. St Petersburg, 1859. Timm had a particularly perceptive documentary eye and was appointed 'battle painter' during the second phase of the Caucasian War. This work well portrays the spirit of those pious and learned Muslim warriors endeavouring to advance the social and religious goals of the Imamate
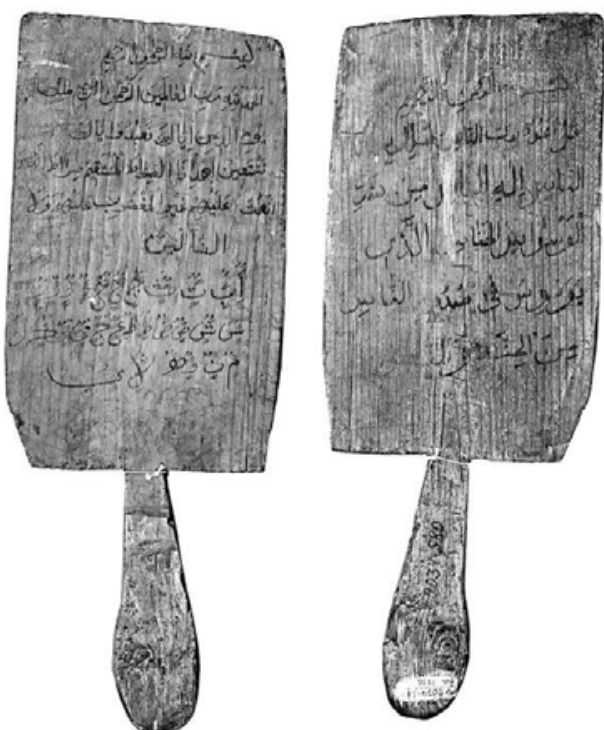

Figure 36. Wooden school tablet with handle for teaching Arabic (chei), collected in the region of the Andiiskoe Koisu (Karata) by A.K. Serzhputovsky (1864-1940) for the then Department of Ethnography of the Peoples of the Russian Empire and Neighboring Countries of the Emperor Alexander III Russian Museum (now the Russian Ethnographic Museum)

In the second five-year plan (1933-1937), the following tasks were set in the field of public education in Dagestan: to provide a complete general education in the native language; to completely eliminate illiteracy and semiliteracy of the adult population and to introduce a sevenyear programme of universal education. During these years, the construction of schools in mountainous regions, including the Tsumadinskiy District, was especially active.

For centuries grandparents and parents had sowed seeds of knowledge in the souls of the Gakvarin people. Prior to the Russian administration involving itself in the provision of public education, the highlanders had studied in local mosques, receiving lessons in the Arabic language, Muslim law (Sharia) and the canons of Islam from educated Ulama scholars. During the years of Soviet power with its atheist doctrine, the school rather than the mosque became the place for acquiring knowledge. In the village of Verkhnee Gakvari in 1932-1933, the first reading hut (izbachitalnya) was established in 1932-1933. This was a unique community club-like institution, providing a centre for cultural and educational work in the Russian language in the villages and towns of the USSR [72-73]. According to 
the first pupils, the building was situated in the Egdada section of the village of Verkhnee Gakvari.

The first teacher was Gadzhi-Magomed from the village of Tindi. A village elder (aksakal), Gadzhi Abdurazakov, recalls that youths from ten to twenty years of age studied together with him.

The school in the village of Verkhnee Gakvari was built in a central location in 1933-1934 by local masters from the Dibirov, Nasibov and Akilov families: It was opened in 1935 as an elementary school providing initial education. In the pre-World War II years, the formation of the Soviet educational system in the village was difficult. Villagers were dubious about some of the teachers - who had been students at the school, some with only a fouryear education. There was distrust of Russian women teachers, who brought elements of Russian culture with them to a human environment in which Muslim laws had for centuries been in force. But even in these conditions there were enthusiasts from the region itself who managed to prevail in spite of mistrust and doubts. They held numerous conversations with the villagers, convincing them of the benefits of education. Although the first teachers were Russian, eventually more and more students from the community and neighbouring regions themselves received a pedagogical education in various specialities in centres of teacher education in Buynaksk, Makhachkala, Dagestan's capital city and other places.

One such enthusiast was Hamsat Kuramagomedova (1912-1990), who devoted her life to teaching and raising children for which she was awarded the Order of Labour Valour [73]. Her path was repeated by other Gakvarians in 1935-37: N. Aliev, Usman Magomedov and Aizanat Hasanova. From 1938-1945, Z. Magomedova and A. Magomedov from the village of Tindi and Sazhid Magomedov from the village of Verkhnee Gakvari worked in the primary school. Neighbours from the village of Nizhnee Gakvari a few kilometres further down the valley also worked as teachers at the school.

These years witnessed the formation of a solid basis for general public education which took over the role of that previously provided by traditional Islamic education. The Ministry of Education regularly sent teachers from various regions of the USSR to the republic. In 1946-1960, Russian and Ossetian teachers worked at the Verkhnee Gakvari School. The language barrier, alien cultural disposition and traditions did not prevent them from teaching and educating the youth of Verkhnee Gakvari as best they could. They were long remembered.

A state decision was made to deploy a network of district schools in 1949. In accordance with the letter of the Ministry of Education and taking into account the plan of universal coverage of children with universal compulsory seven-year education, the Executive Committee of the district council decided to reorganize the Verkhnee Gakvari primary school into a seven -year school (1953-1973). Neighbours from the village of Nizhnee Gakvari a few kilometres further down the valley also worked as teachers at the school.

From 1973 to 1981, the school was transformed into an eight-year school, a new school being built. The first graduation took place in 1975 . Young villagers, overcoming all difficulties, prepared to leave their homeland to study further afield. This was particularly difficult for mountain women, as parents did not want to let their daughters go to study far away in the city (an uncomfortable eight hours bus ride). But still there were those who were not afraid to go and study, entering universities, colleges and technical schools. Many of them became teachers, doctors, drivers, nurses, machine operators, etc. A number of well-known figures in the republic have studied in the Verkhnee Gakvari School.

Amongst the school's notable women figures was Saniyat Osmanova, who graduated from the Buynaksk Pedagogical College. She was the first woman teacher from the village and showed all its women the way to the world of a solid education. Salimat Magomedovna Askhabova was the first woman in the village to receive a higher education. She graduated from the Gamzat Tsadasi Pedagogical Institute and subsequently worked as a teacher in the villages of Gadiri and Agvali. From 1981 to this day she has been working as a teacher of Russian language and literature in her native school. Thanks to her, many girls from the village have gone on to study at university and other centres of higher education. Her students now work in different parts of the republic and abroad.

The first graduation from Verkhnee Gakvari secondary school occurred in 1983, the school having become one of the best in the area. In 2000, it was renamed after Huseynov Zakaria Dengaevich, who died at the hands of bandits invading the Tsumadinskiy District. From 2003 to the present day, the school has been headed by Magomed Magomedovich Ismailov [73]. The school is currently fully staffed with local inhabitants. Many teachers are ex-pupils and apprentices of those teachers who were at the origins of state public education in the village.

Despite the relatively small number of students at the Verkhnee Gakvari School, the results of their participation in regional and republican academic events and sports are impressive. In a discussion with a local resident about the reason for the particularly high level of academic accomplishment compared to urban students among those who had received their education at this and other small community schools in the district, the answer was that this was not only because of the quality of teaching in itself but because village school classes were small and that the teachers were often relatives and thus commanded respect and attention.

In 2008, the school won the competition for the Best School of the District and received a presidential grant of one million rubles. The school is included in the National Register of Leading Educational Institutions of Russia (2011).

The school pays great attention to the upbringing of its children and (like those of other communities in the Tsumadinskiy District) is noteworthy today for the dedication and erudition of its staff. Environmental education occupies a significant place in its pedagogical priorities. Whereas the Islamic values underpinning community consciousness for so many centuries has a theological basis, under the new state school system the orientation of subjects relating to the natural world and its use was imbued with the empirical objectives of Russian Tsarist and Soviet research into all aspects of science relating to native flora and fauna, biology and ecology [74] as well as applied sciences in the fields of agronomy, agricultural production, forestry etc. The primary underlying intention of state public education was to educate students across the USSR with consistent and commonly-shared educational values who could contribute to advances in the quality of life and the quantity and 
quality of state production in all related fields of endeavour.

\section{The Place of Environmental Education in Verhknee Gakvari School today}

Practical environmental education in Verhknee Gakvari School is considered the basis of the school educational process. It is consistent with modern post-soviet public and higher education with an increasing emphasis on understanding and respecting the environment, the sustainable utilisation of natural resources and agricultural systems and the preservation of natural biodiversity and ecological management in response to human impacts and climate change. In a settlement with a devout practicing Muslim population of teachers and students there is also now freedom to introduce Islamic concepts relating to nature into teaching in school. as follows:

The school's expressed philosophy in this regard is

In recent years, the process of awareness of the need for the conservation and rational use of nature, the importance of environmental knowledge and skills for the further development of society and the preservation of the life of present and future generations of people has been advancing at an ever increasing pace. Therefore, we are in need of a new ecologised culture that will transform a person's social environment and turn it towards the true values of civilization - freedom to work in a calm and dignified life in a normal stable environment.

The ecological crisis and the need to find ways out of it dictate the need for the legislative support of the environmental policy of the Russian Federation.

Ecology today is a new methodological approach that should permeate all school education. This requires a change to many stereotypes of thinking throughout the educational process and in all academic subjects.

Environmental education and enlightenment of the population is the most effective way to solve the global problems of mankind.

Today, no one doubts that environmental education in general is of great importance for the formation of Russia's environmental culture and, as a result, a decrease in its anthropogenic load on the biosphere. It is also obvious that the main emphasis of environmental education should be placed on general education in schools. Today the school is the only social institution through which, in one way or another, the entire population of Russia passes.

School is the place where people can be taught to take concerted action aimed at improving the environmental situation of the region where they live and of the country as a whole. The sprouting of new education in the interests of sustainable development is possible only where there is a system of continuous education about the environment.

In the Verkhnee Gakvari School work is undertaken to protect flora and fauna and to identify, describe and protect unique natural monuments. The protection of the water and soil resources of each settlement is of no small importance in the education of a patriot who loves and protects his homeland and its nature."

During the Soviet period significant work was done by the state forestry services to protect and utilise the vast forest resources of the upper headwaters region of the Andiiskoe Koisu.
The Tsumadinskiy State Forestry Enterprise was established in 1934 and deals with the protection and rational use of district forest resources. The main role of the forests is not economic but in nature conservation and protection. The importance of forests in water regulation, prevention of soil erosion, prevention of landslides, talus and mudflows is invaluable; it also improves the microclimate.

The average forest cover of Dagestan is $7.3 \%$, while the average forest cover of the Tsumadinskiy District is $15 \%$. In terms of vegetation zoning, the territory of the forestry belongs to the high-mountain forest-growing area of pine and birch forests. Pine forests prevail $-62.6 \%$, birch forests $-29.1 \%$, oak $-3.6 \%$. Small areas are occupied by hornbeam, aspen, alder, linden and others.

By the late 1960s some of Verkhnee Gakvari School's teaching staff had an education relating to biology, ecology and forestry, stimulating them to take advantage of the professional foresters working locally in the district to establish a school forestry around 1970 . The instigators of the school forestry were two great enthusiasts of environmental protection at the school and in the village generally: Khakim A. Abdurazakov, biology teacher and Magomed A. Osmanov, geography teacher. Under the latter's leadership, a significant local pine plantation was established by cutting down a mixed birch forest on an area of 5 hectares and replanting pine. Following the collapse of the USSR, this school forestry ceased its activities.

\section{Establishment of New School Environmental Organisations} The legacy of the Soviet period school forestry amongst exstudents and teachers, which together with growing public interest in biology and ecology among new teachers with relevant backgrounds and enthusiasm in these areas and the religious beliefs within the community relating to nature, led to new major new initiatives at the Verkhnee Gakvari School which have impacted on the community to the present day in its maintenance of the long traditional interrelationships between the various sectors of the local ecosystem which have contributed to the community's distinctive socio-ecological production landscape or cultural landscape (Fig. 37, 38).

Thus, two new environmental organisations were established at the school, the Edelweiss Eco-Group (founded 2009) and the Berezka School Forestry (founded 2010), both groups collaborating in many activities.

The ecological education provided at the school is helping to develop citizens who observe environmental norms and rules and lead healthy lifestyles.

In the classroom and in extracurricular activities teachers pay especial attention to students' ecological education. Lesson by lesson in Verkhnee Gakvari teachers endeavour to convince children that man is not the king of nature but a part of nature and that the future of man himself depends on the attitude of man to the environment. Through its activities the school is achieving the goal that its children become aware of the need to maintain global balance and of everyone's involvement in environmental problems. This can be judged by their meaningful abstracts, presentations, performances at competitions, Olympiads and conferences at both regional and republican level. 


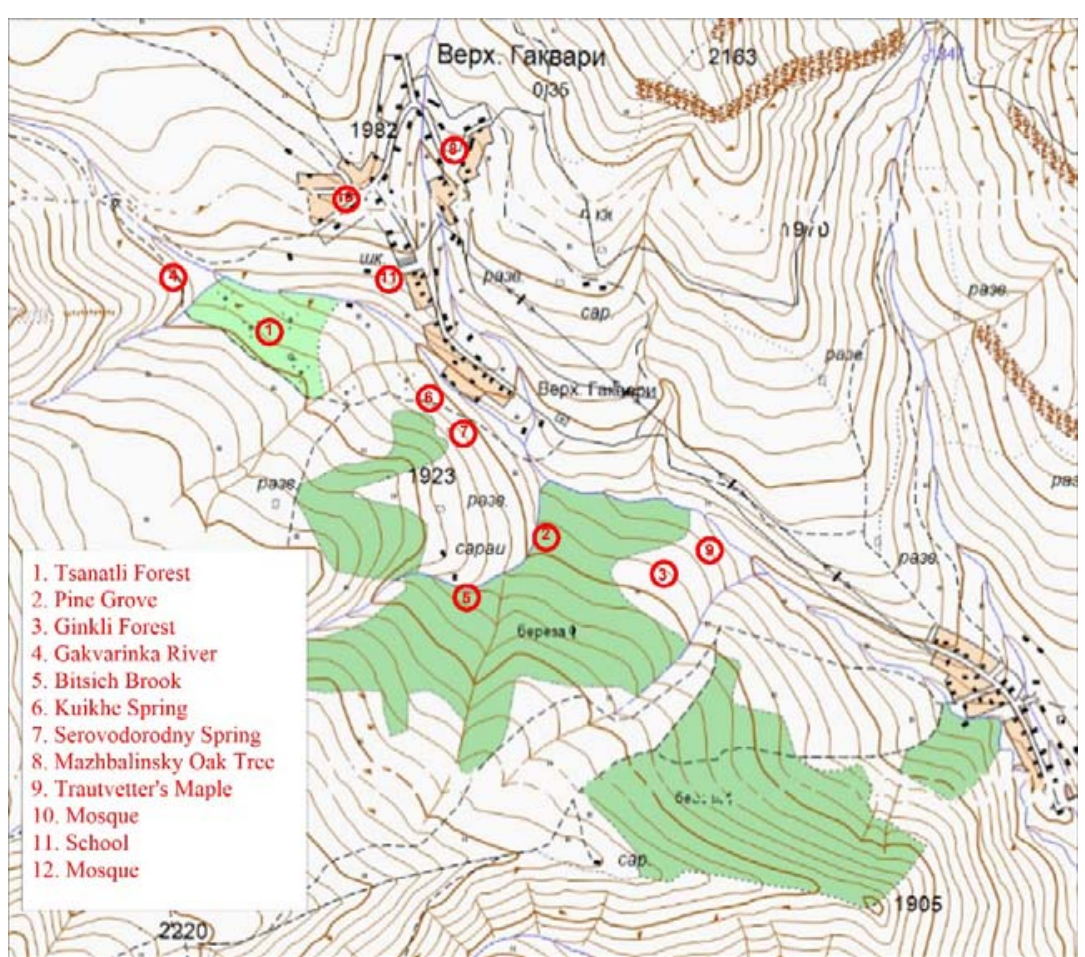

Figure 37. Topographic map with indication of key features (red circles) under environmental management by the students and staff of Verkhnee Gakvari School. Cartographic annotations by Abdulgamid Teymurov

Note: The areas in green on this map do not accurately represent the areas under forest today - see Fig. 39 for accurate depiction

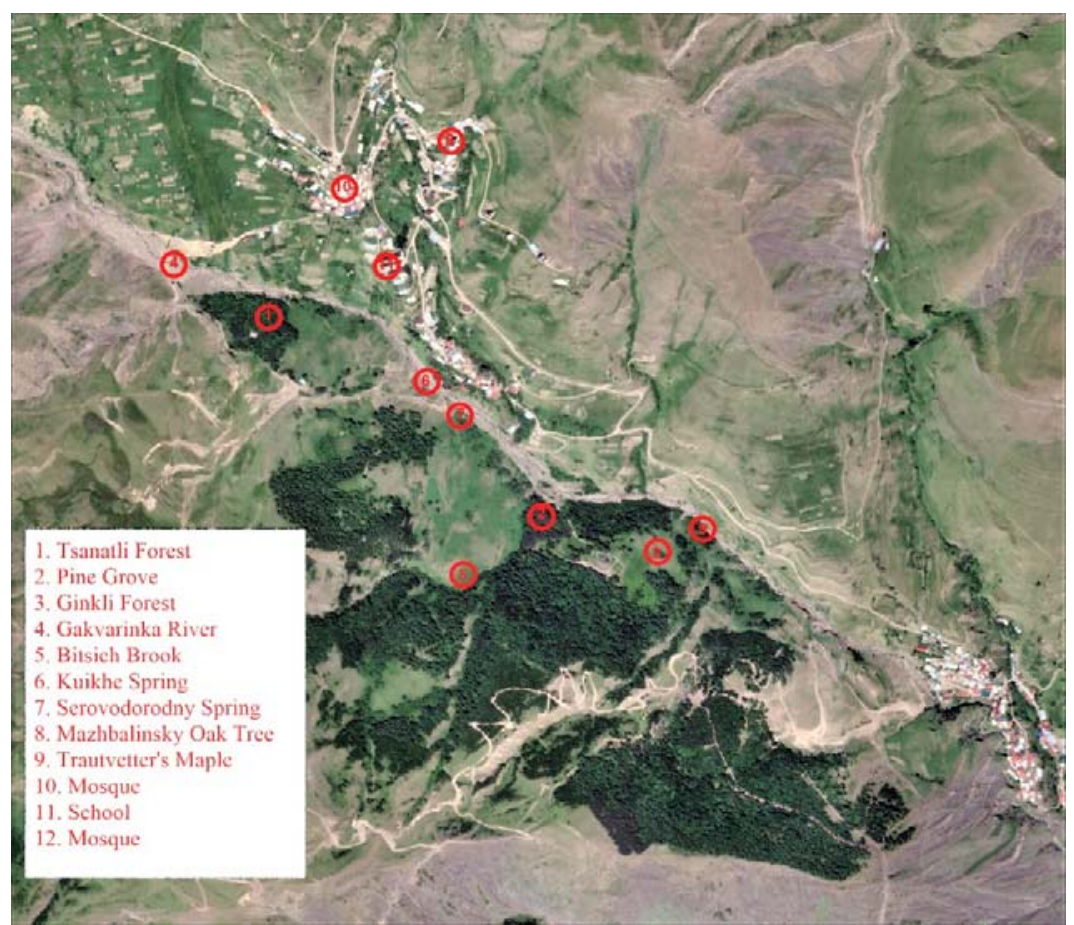

Figure 38. Satellite image of features (red circles) in the territory of Verkhnee Gakvari under environmental management by the village school and community. The village of Verkhnee Gakvari appears in the lower right corner of this photograph. Cartographic annotations by Abdulgamid Teymurov

\section{Edelweiss Eco-Group}

The Edelweiss Eco-Group's goals and objectives are: school of garbage.

- Cleaning the territory of the village and

- Organising and conducting environmental raids and subbotniks (weekend voluntary community clean ups - inherited from the Soviet period).

- $\quad$ Fostering environmental culture among students and adults through organizing community lectures, production of wall newspapers and promotional appeals.

- $\quad$ Actively participating in school-wide, district and republican competitions and environmental and biological Olympiads.

Near the village of Verkhnee Gakvari, members of the Edelweiss Eco-Group have established a $5 \mathrm{~km}$ long ecological trail linking many of the natural features in their care (Fig. 39-41):

- Gakvarinka River 
- $\quad$ Tsanatli mixed pine-birch forest

- Swamp with a spring

- Bitsich Brook

- $\quad$ Ginkili birch forest

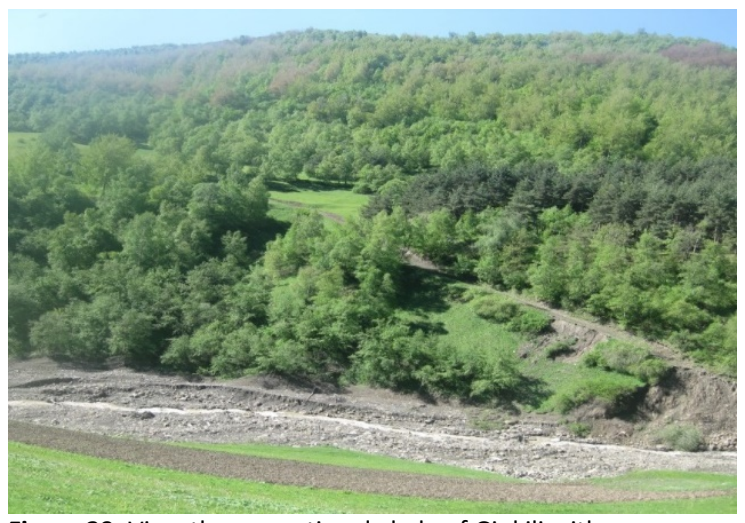

Figure 39. View the recreational glade of Ginkili with Gakvarinka River in foreground. The Pine Grove is in the right centre of the photograph
- $\quad$ Forest glade with a large masonry and concrete swimming pool constructed by community volunteers

- Hydrogen sulphide (Severodorodny) spring.

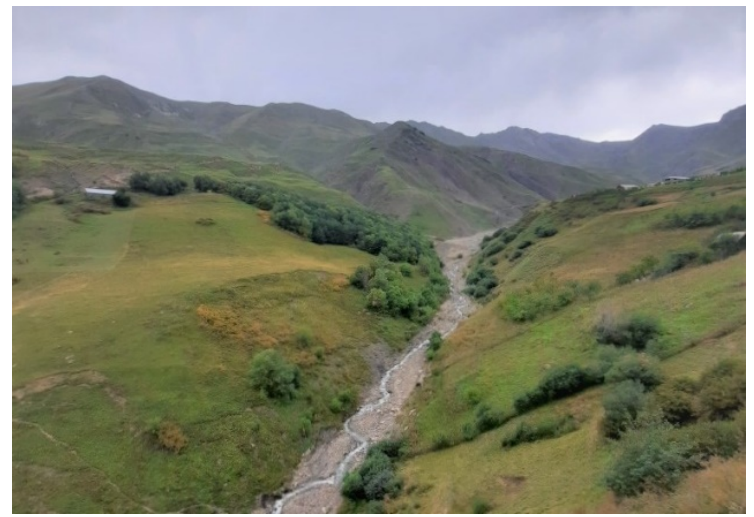

Figure 40. Course of Gakvarinka River with Tsanatli pasture and forest in left of photograph

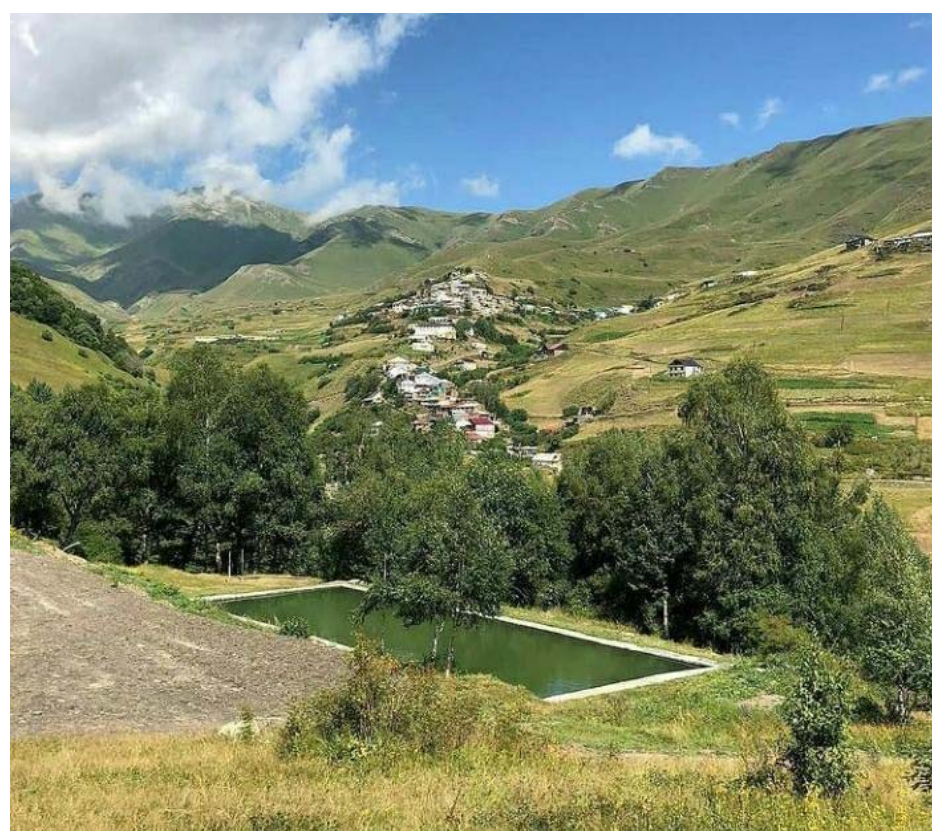

Figure 41. Ginkili Forest recreational glade and pool with village and its croplands and pastures. Mid-summer

Almost all school students and kindergarten pupils pass along the trail every year, getting acquainted with the nature of their native land and the rules of eco-friendly behavior in the forest. Here are conducted the traditional annual school-wide excursions "Golden Autumn" and "Towards Spring".

\section{Berezka School Forestry}

In May 2010, on the initiative of the Verkhnee Gakvari school director, Magomed M. Ismailov, the Berezka School Forestry was created in the place of the earlier Soviet period school forestry. A young specialist was appointed as its head, biology teacher, Shamil M. Ismailov. A Young Forester educational circle was also established, led by ecology teacher, Patimat K. Nurmagomedova.

In accordance with a charter approved by the director of the Tsumadinskiy State Forestry Enterprise and the director of the Verkhnee Gakvari secondary school, a forest area was assigned to the Berezka School Forestry for carrying out forestry activities with an area of 32.7 hectares.
The goals and objectives of the Berezka School Forestry are:

- $\quad$ Educating students about their environment.

- Expansion and deepening of students' knowledge in the field of natural sciences and implementation and realization of their creative potential.

- Teaching student's special skills in research work as well as providing vocational guidance.

- Carrying out activities for the study and protection of forests, planting and sowing forest cultures, promoting natural forest regeneration and landscaping the school and village territory.

- Introducing rare and endangered forest species of forest in an educational and experimental plot.

- Promoting knowledge about the forest among all participants in the educational process and the broader local community.

- Organizing and holding of evenings, weeks, meetings, Olympiads and competitions dedicated to the forest. 
For the preservation of the unique biodiversity of the forests of the Tsumadinskiy region and the rational use of forest resources, the following actions on the part of the Berezka School Forestry were determined as necessary.

To study the flora of forest vegetation in Tsumadinskiy District, to identify the types of trees and shrubs to be protected and protected.

As a result of field research and analysis of literary sources, the forest flora of the Tsumadinskiy District was identified as comprising 18 species of trees, 14 species of bushes and 6 species of shrubs and semi-shrubs. The ecological characteristics of the forests of the Tsumadinskiy region were determined and examples of human use of certain types of forest flora were identified [75-76].

Carry out work on afforestation, reforestation and protection of unique forest areas in each settlement.

Conduct wide-ranging educational, explanatory work among various segments of the population on the protection and respect for forest resources.

To address these latter goals, the school focuses on the ecological state and species diversity of forest plants in the Tsumadinskiy District and their importance in human life. To enable this it has created a material and technical base for the effective operation of the school forestry. This includes plots of land, work premises, furniture, communication equipment, computer and office equipment, cartographic and methodological materials, combined training workshop with measuring instruments and tools. There is also a biology room for practical work in forestry and ecology and a permanent exhibition space for products derived from natural materials and exhibitions of

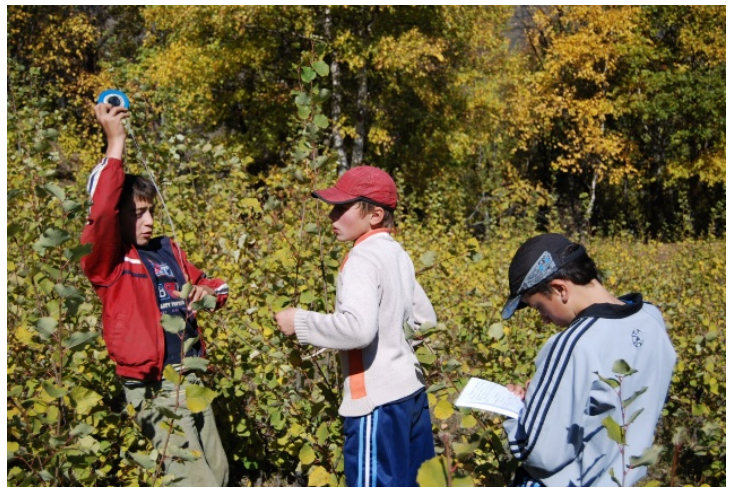

Figure 42. Members of Bereska School Forestry measuring growth of young trees as part of their forest monitoring programme

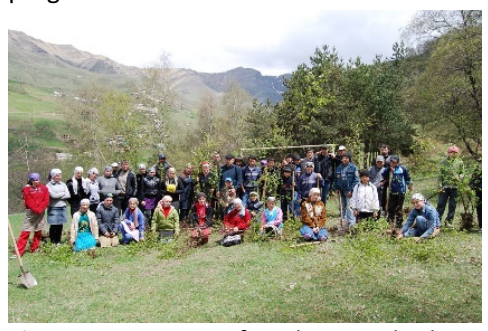

Figure 44. A group of students and othe villagers gathered for a tree planting subbotnik. The saplings they are holding were grown by them at the school

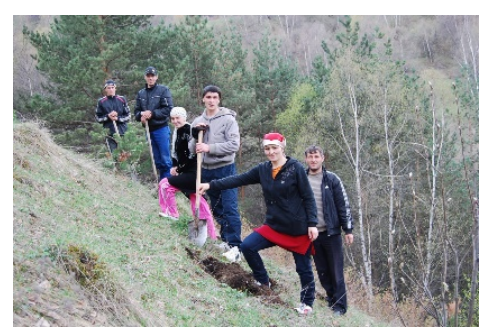

Figure 45. Reforestation project. Students preparing ground for planting young trees which they have grown from seed in the school nursery students' work. There is a summer teaching area for briefings and theoretical studies.

To conduct practical classes, the school has the following areas that are in perpetual use:

- School training and experimental plot of 0.5 hectares.

- School arboretum adjacent to the school of 0.12 hectares.

Technology is taught by Rabiat S. Magomedova and Shamil M. Ismailov, biology teacher who is head of the school forestry and responsible for the work of the school training and experimental site.

For the implementation of pre-profile and profile training within the Russian state educational system, the school cooperates with the Dagestan Institute for the Development of Education.

The school forestry undertakes the whole range of annual and ongoing activities associated with a professional forestry enterprise, including:

- Monitoring state of forest

- Thinning and clearing

- Collecting seeds and fruits of trees and shrubs (oak, pine, rowan, maple, linden and viburnum)

- Sowing seeds of tree species under the forest canopy

- Planting and care of seedlings in nurseries established in the school arboretum

- Forest fire prevention using explanatory material provided by the head of the Tsumadinskiy State Forestry Enterprise (Fig. 42-46).

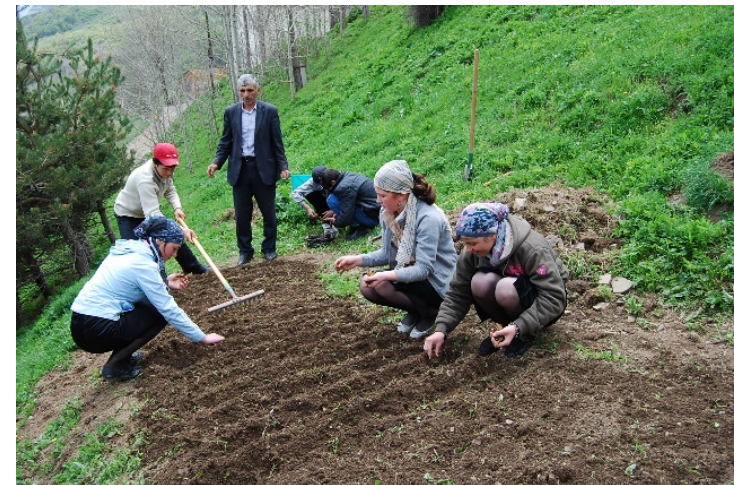

Figure 43. Students and teacher in nursery preparing soil for planting.Verkhnee Gakvari
A terrace has been established in front of the Verkhnee Gakvari School, where aspen, birch, pine, wild rose and willow grow. The school also has an orchard in which 105 apple trees of the best varieties from Michurinsk have been planted. In 2006-2007, the garden was recognized as one of the best in the republic.

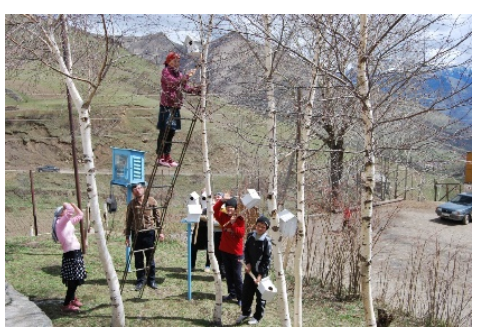

Figure 46. Students of Verkhnee

Gakvari School installing bird nesting boxes that they have made
Students also manufacture and erect bird nesting houses and bird feeders and collect wild medicinal and herbal materials traditionally used in the community. They also monitor and maintain three water sources or springs valued by the community (Fig. 47,48 ). 


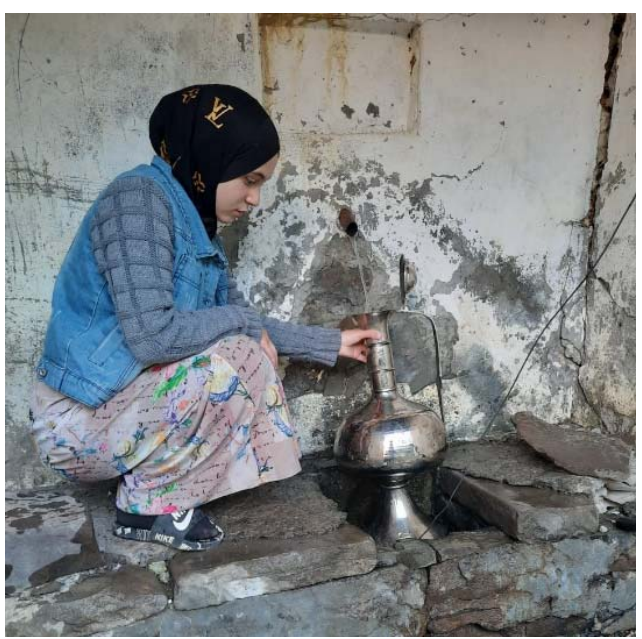

Figure 47. Filling a traditional metal water jug at the Kuikhe spring, Verkhnee Gakvari

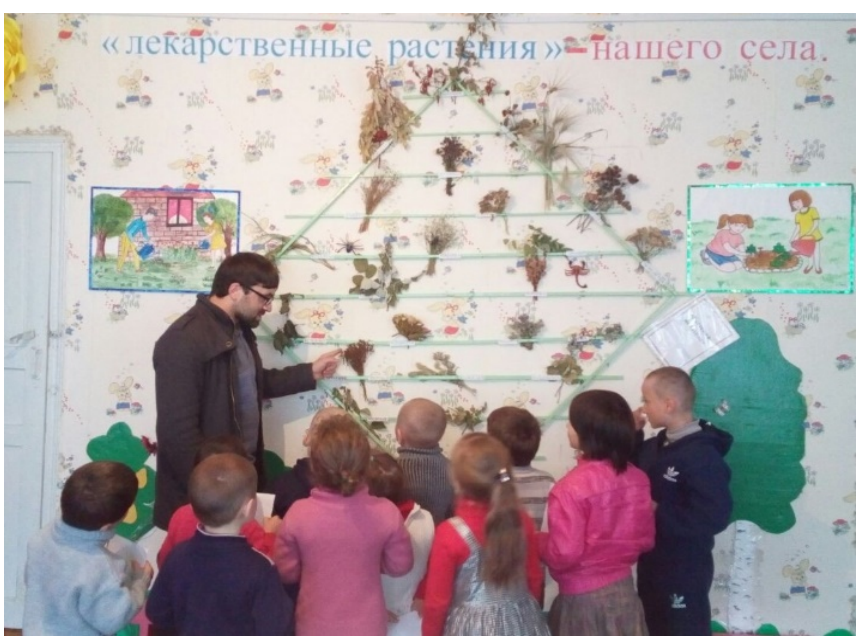

Figure 48. "Medicinal Plants of Our Village". Biology teacher, Shamil Magomedovich, showing examples to a class of young pupils
In 2016, the school organized pre-professional training in the agronomic profile according to the Russian system. An agreement was signed implementing the professional programme called "Vegetable Grower of Protected Soil" with the Sh.I. Shikhsaidova Buynaksk Agrarian College.

The following is a listing of work done by the Berezka School Forestry in a characteristic academic year (2016-2017): forestry.

1. Caring for the forest assigned to the school

Removal of unhealthy, crushed and damaged trees as a result of early snowfall, was carried out on an area of about 3 hectares. 40-50 year old aspens had particularly suffered. They had collapsed and the tops of birches, lindens and hornbeams were also damaged. Thinning operations were carried out to increase the overall growth per unit area and improve sanitary conditions in the forest by increasing resistance against harmful factors.

In order to reduce competition between seedlings, thinning was also carried out in the pine area of the school arboretum. Clearing was carried out in a closed pine forest area in the Ginkili forest and lower branches and underdeveloped pines were also removed.

Selective felling for timber harvesting was not carried out, as villagers use wood less and less as fuel, replacing it with natural gas (in cylinders) and electricity. For the same reason, it is now rare to find poachers and violators of forest legislation in the forest.

2. In the spring of 2016, members of the School Forestry and school teachers under the guidance of Shamil Ismailov, seeds were sown in the Ginkili forest glades over an area of about 1 hectare. The seeds were provided by the Tsumadinskiy State Forestry Enterprise. Class teachers and students of grades 6-11 were instructed in advance on general safety, fire safety and rules for sowing pine seeds.

3. At the same period, 2-3 year old birch seedlings were dug up for planting in the school arboretum and some unused lands in the village.

Instructions on tree planting rules were conducted by teachers of biology, chemistry, ecology and geography.

4. During the summer, plantings were cared for (watering, protection against eating by livestock, weed removal) in the school arboretum, mainly by the members of the Young Forester educational circle.

5. In order to expand the forested lands, nurseries were established in the school arboretum and in the Tsanatli forest area, as being the most convenient and protected places close to the school. Seeds of rare species of Trautvetter's maple and blue spruce were sown.

6. The tending of the nursery was undertaken by members of the Edelweiss Eco-Group. Crops of maple seeds turned out to be very sparse due to being picked by birds and eaten by rodents.

7. Students collected seeds and fruits of wildgrowing ornamental trees and shrubs in an amount sufficient to start a nursery the following year.

8. Birdhouses and feeders were made and hung in the school arboretum by members of the Young Forester education circle, aided by technology teacher, Gusen M. Ismailov.

9. The School Forestry conducted much explanatory work in the community regarding the benefits of forest dwellers and the need for their protection: birds, animals and beneficial insects. A large accumulation of anthills in the Ginkili and Bitsich forest areas have been identified and taken under protection.

10. The Ginkili forest area is very popular among villagers, visitors and tourists. However, there are some who violate the rules of behavior in nature and in the forest. Members of the school forestry repeatedly extinguished embers of fires they left behind in the pine forest area.

11. Increase in areas with naturally renewable forest species were identified, described and measured as follows:

- Aspen - 1.2 hectares (1-4 years)

- $\quad$ Birch -4 ha (1-7 years)

It was concluded that the increase in forest areas is due to a decrease in grazing livestock in areas adjacent to the forest, as birch and aspen are mainly renewed by root suckers. The length of year-old shoots measured by members of the Young Forester educational circle was as follows:

\section{- Aspen: $85-110 \mathrm{~cm}$}

- $\quad$ Birch: $40-55 \mathrm{~cm}$

- $\quad$ Pine (spread by seed): $4-7 \mathrm{~cm}$.

Individual specimens or whole groups of tree species (birch, mountain ash, pine, etc.) of around 50-70 specimens have spread even higher into mountain pastures and alpine meadows, which is also the result of the activities of various birds and animals.

Older villagers said that there used to be birch forests up to the very peaks. This is evidenced by the remains of logs carried by mudflows from the mountains. Members of the Berezka School Forestry conduct explanatory work among schoolchildren and the local population to prevent the unregulated appearance of young birch and aspen forests and spreading of pines seeds by livestock.

12. In 2017, members of the Edelweiss Eco-Group (together with graduates of previous years) participated in the maintenance of springs at the base of the forested 
areas. The purpose of the maintenance arrangements was to provide vacationers and guests with drinking water.

The water of the Kuikhe spring is unique in its properties - it is one of the softest among all the drinking water springs in the Tsumadinskiy District (data derived from chemical analyses by members of the Edelweiss EcoGroup). Another spring, the Serovodorodny (contains hydrogen sulphide: people use the water to treat skin diseases and remove kidney stones. It is located at the base of the northern slope, $300 \mathrm{~m}$ southeast of the Egdad microdistrict of Verkhnee Gakvari village. The spring water has long been used both by locals and people outside the area. Near the source is a quarry where, in Soviet times, high-quality rubble stone was mined, including with the assistance of rock explosions. An elderly resident, A. Gadzhi, said that the source's flow rate used to be twice as much as it is now and it is assumed that the amount of water in the source has decreased as a result of blasting and deforestation along the slope above.

Protective measures undertaken: Through the efforts of members of the Edelweiss Eco-Group, the spring was improved, thanks to the financial support of the head of the village administration, Magomed Magomedov, in 2010. The group undertook explanatory work among those building new houses so that they do not carry out blasting operations in the quarry at the base of which the source is located.

A third spring is located in the Ginkili forest.

Another water source of local significance is the Zhelezisty (Iron) spring, which is located $3 \mathrm{~km}$ north-west of the village of Verkhnee Gakvari. It located near a livestock route and therefore is exposed to the impact of sheep, goats and cattle through trampling and pollution of the area around the source. It is necessary to periodically maintain the area of the source and the source itself: lining it with stones and cleaning it of silt and dirt. The need for protection is due to the fact that this source is the only one on village territory whose water contains iron ions in this quantity. Villagers use this water as:

- A medicinal drink against iron deficiency anemia.

- $\quad$ For kneading dough - producing a light, tasty bread. A village elder, Zagid-gadzhi Ismailov, said that the water previously was frequently used, including against heartburn. The water has an iron taste and the stones around the source are covered with a brownish-red coating.

Protective measures undertaken: Members of the Edelweiss Eco-Group have taken the source under their protection and periodically maintain and clean it. Thanks to their efforts, the source has been declared a natural monument of rural municipal importance.

Protective measures required: As the spring's water is often used by the local population, it is necessary to periodically re-arrange the source: to deepen it to form a reservoir, to lay out the bottom with flat stones at the bottom and to enclose it with a metal mesh or stone fence to prevent contamination by livestock.

A more thorough chemical analysis of this water is required, especially for the identification of trace elements. In this regard samples have been provided to the Institute of Ecology and Sustainable Development of Dagestan State University.

13. Medicinal and food plants and mushrooms were collected in forested areas. In 2017, a record number of mushrooms were harvested: they were collected in bags, buckets and even whole sacks. The villagers mainly boil them, wring the liquid from them and store them in refrigerators and, as needed, fry them in vegetable oil.

14. Members of the School Forestry collected about $80 \mathrm{~kg}$ of medicinal and herbal raw materials in compliance with officially permitted collection periods.

Among the medicinal plants of the forest, birch (buds) are popular among the local population as are pine (buds, resin), mountain ash (fruits), oak (bark), blueberries (berries, leaves, stems), wild rose (fruits, roots), raspberries (leaves, fruits), lingonberries (berries, shoots), stone bramble (berries), male fern (rhizomes), etc. (Fig. 49).

Members of the Edelweiss Eco-Group also systematically cleared forest glades and forested areas of debris - broken bottles, plastic bags, metal cans, etc. They undertook explanatory work about environmental protection, respect for the forest and its inhabitants and the study of the flora and fauna of forests and other phytocenoses surrounding the village. They also participate in various environmental conservation activities and competitions at regional and republican levels (Fig. 49).

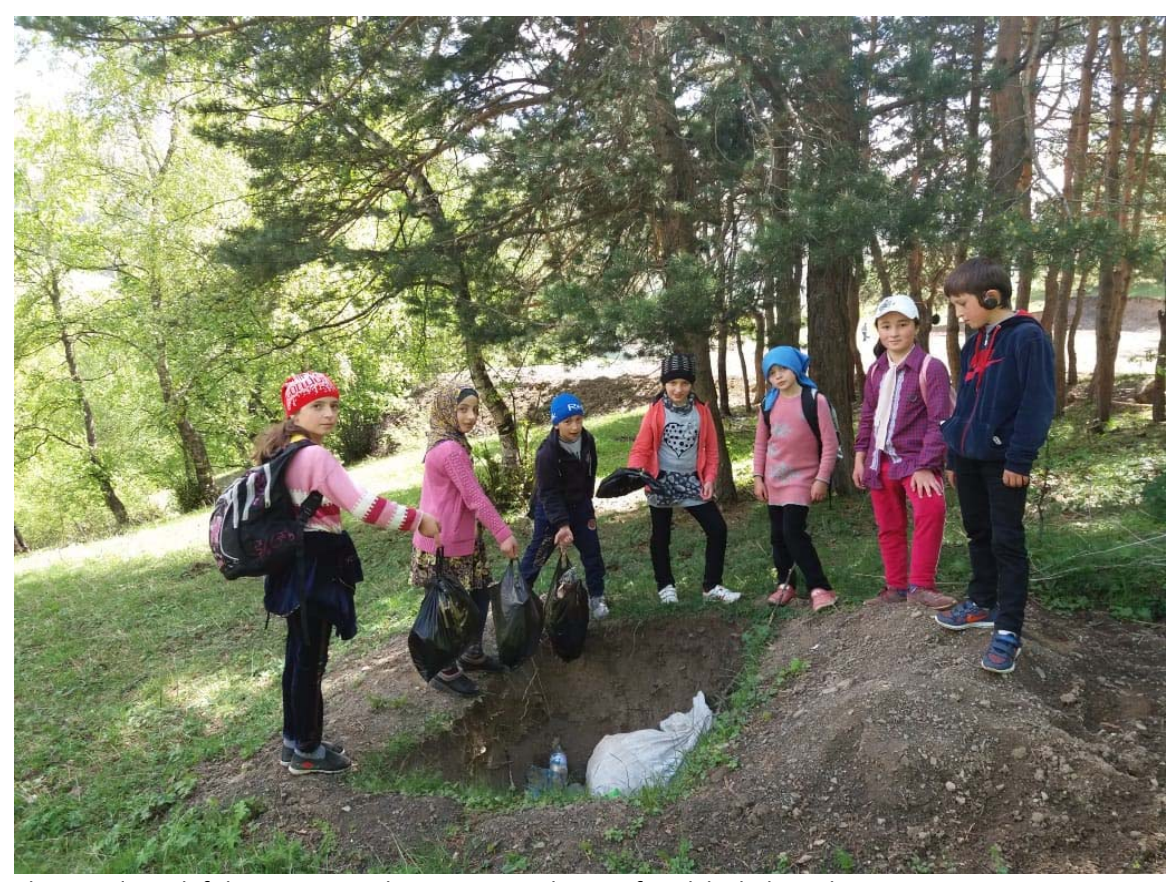

Figure 49. Students burying litter left by visitors to the recreational area of Ginkili glade and Pine Grove 
Natural Monuments of Rural Significance

In 2013, research work by members of the Berezka School Forestry resulted in the identification, protection and declaration as natural monuments of rural significance at the municipal level the following natural objects:

- $\quad$ The Mazhbalinsky giant oak tree.

- The Tsanatli forest area with the endemic Caucasus species, the Radde birch, which are included in the Red Data Books of the Republic of Dagestan and the Russian Federation.

- An example of a Trautvetter's maple (a rare, beautiful ornamental tree endemic to the Caucasus) with a height of $15 \mathrm{~m}$.
- $\quad$ The pine grove which is the only area of pine forest within birch forests in the Tsumadinskiy district.

The village of Verkhnee Gakvari is of significant recreational importance for the Tsumadinskiy District. These natural objects are the subject of close attention of the members of the Berezka School Forestry who have been actively working toward the adoption of regulations by municipal and district authorities for their protection.

Mazhbalinsky giant oak tree: The giant oak is located in the Mazhbal microdistrict (Fig. 50). The age of the oak, according to village elders, is about 500 years. Its diameter at 2 metres from the base is $1 \mathrm{~m}$ and its height is $30 \mathrm{~m}$. A grandmother said that near the tree was the house of Sheikh-Alim Ali Mazhbalinsky, who was a folk healer who cured people with holy water, etc.

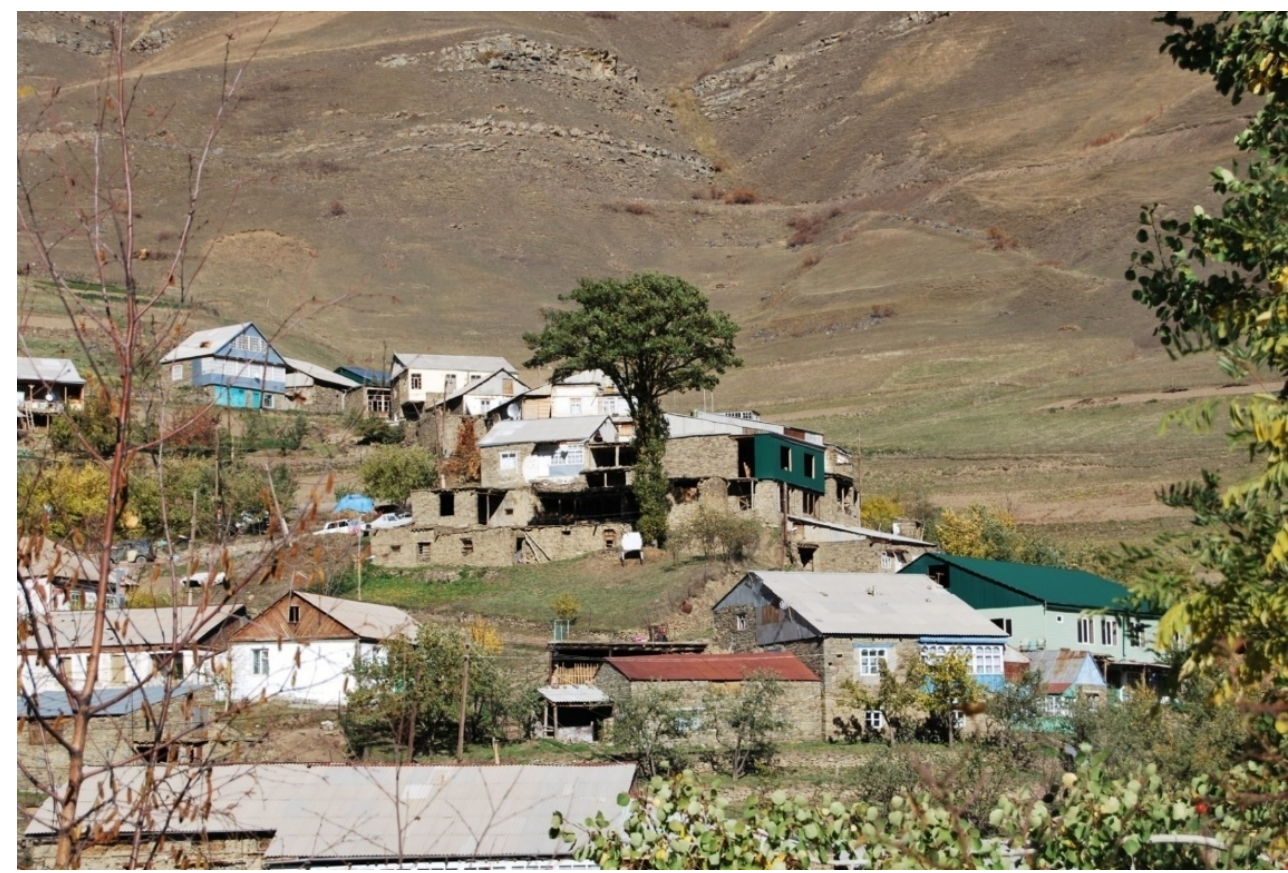

Figure 50. The microdistrict of Mazhbal and its giant oak tree which has been designated a natural monument of rural municipal importance

Current state: every year, side branches appear on the trunk of the tree, in some places the bark is covered with mosses and lichens and birds arrange their nests on it; the oak blossoms and bears fruit, but less and less every year.

Conservation measures taken: Through the efforts of the head-teacher of biology and members of the Edelweiss Eco-Group, the oak has been taken under protection: an iron shield was installed with information about the protection of the oak as a natural monument.

The members of the Edelweiss Eco-Group appealed to the head of the Verkhnee Gakvari Village Council about the need to declare the oak as a natural monument of the Verkhnee Gakvari village resulting in an appropriate decree. Members of the Edelweiss Eco-Group keep the area around the oak tree clean.

Necessary protection measures: The giant oak is a unique natural monument not only of local importance but also of the Tsumadinskiy District and the Republic of Dagestan. For a start, it is necessary to acquire the area around the tree and to fence it off with a metal mesh. Appeals have been made to the head of the district and the district meeting of deputies with this proposal.

Trautvetter's maple: There is a separate $15 \mathrm{~m}$ high specimen of Trautvetter's maple, endemic to the Caucasus, among the birches in the Ginkili locality (Fig. 51). It is especially beautiful in autumn, when the leaves take on a bright yellow and then reddish colour.

Present state: The tree is located on the slope of the northern exposure with a $30^{\circ}$ incline. It is surrounded by a natural protection of wild rose, birches and oaks. Access to the tree is difficult for cattle.

Protection measures undertaken: Young school ecologists are conducting explanatory work among students and the village population about the need to protect this unique and beautiful tree in our forest not only from the threat of illegal felling but from the breaking of branches and from collecting sap, etc. By decree of the Head of the Village Council of Verkhnee Gakvari, this Trautvetter's maple has been declared a natural monument of rural municipal importance.

Protection measures required: It has been deemed necessary, together with the Tsumadinskiy Forestry State Enterprise, to take measures to propagate the Trautvetter's maple by the nursery sowing of seeds and by planting grown seedlings in school arboreta, in forest plots and near administrative buildings as a highly beautiful and ornamental tree species. The first steps in this direction have already been taken. Young ecologists already sowed 
seeds in a nursery arranged in a school arboretum in autumn 2013. Members of the Berezka School Forestry together with members of the Edelweiss Eco-Group applied to the school director for financial support for this project.

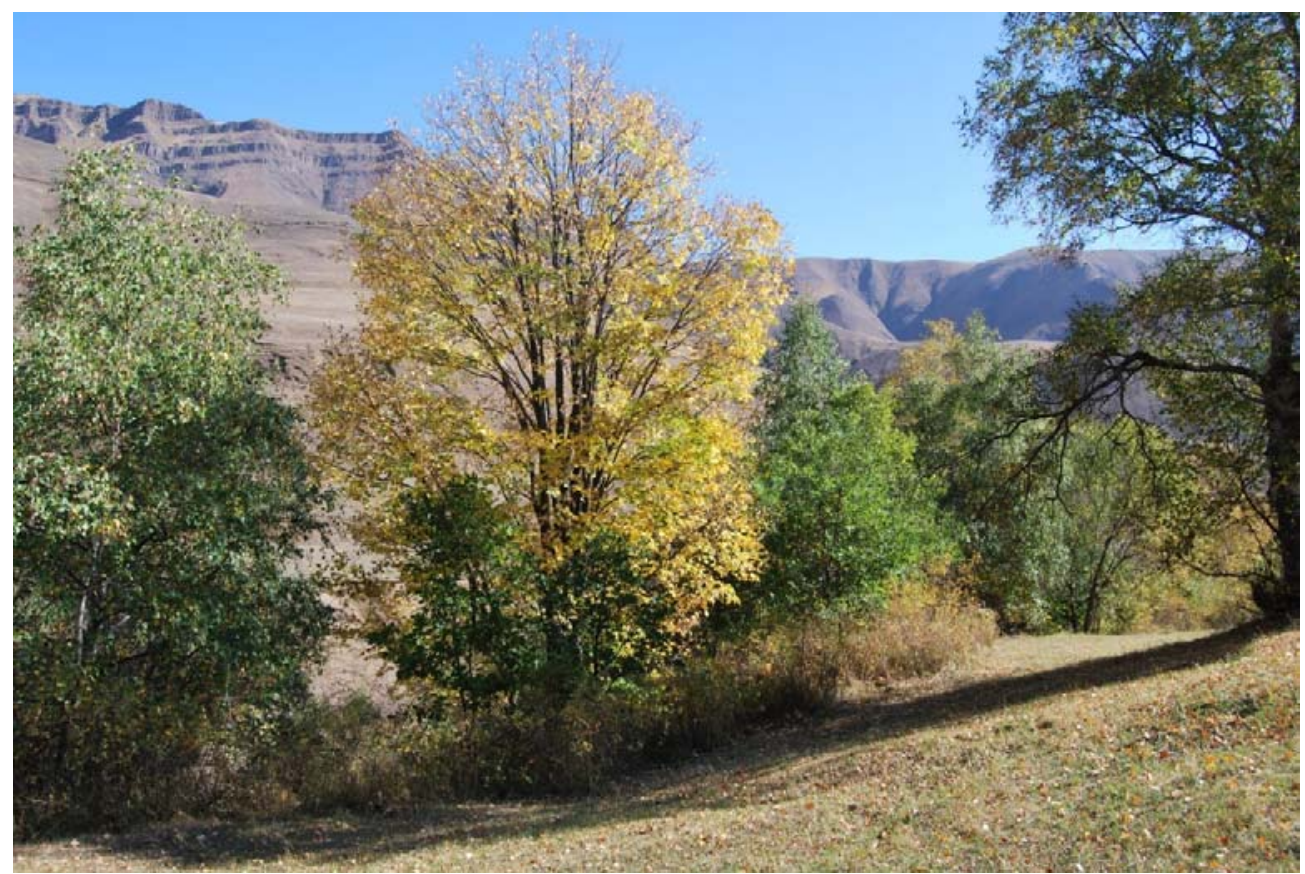

Figure 51. A lone specimen of Trautvetter's maple at the edge of Ginkili Forest with its autumn foliage. It has been designated as a natural monument of rural municipal importance and saplings are being grown from its seeds in the school nursery

Pine Grove: A pine forest near the village was planted in Soviet times and occupies approximately 2 hectares. It is the only plot of pine amongst a birch forest planted in Soviet times. The pines are now about 55 years old. The grove is now of significant recreational value. The villagers have constructed a large natural spring-fed 30 swimming pool $150 \mathrm{~m}$ to the east.

The site is subject to strong anthropogenic impact. It is a favorite vacation spot for villagers and visitors. The soil is also trampled and exposed to cattle. In snowy winters, under the weight of snow, the tops of trees break or trees roll to one side due to a weak root system and the closeness of their plantings. Villagers sometimes cut down pines for their household needs without the consent of the school forestry administration and the state forestry enterprise does not take effective protective counter measures. The forester performs his functions as a formality; there is no remuneration. The forest protection system has completely collapsed and this is why have undertaken the difficult mission of protecting and conserving our own local forests.

Protective measures undertaken: Young ecologists from the Verkhnee Gakvari School took this part of the forest under protection in 2010, the year of the establishment of the Berezka School Forestry. Much explanatory work has been undertaken among the student and parent community about the need to protect this site from forest poachers and un-monitored tourism, as a result of which the forest area is littered with garbage, plastic and glass bottles, papers, packaging material and food leftovers. Cooking fires are also lit in the wrong places. Every year, members of the Edelweiss Eco-Group clear the pine forest of debris by burying it and burning paper waste.

Protective measures required: Assistance is needed on the part of the management of the Tsumadinskiy State Forestry Enterprise and the village administration in the protection and conservation of this forested area of unique value to the village. The efficient management of this site will benefit both the village community and visitors.

In 2017 the Berezka School Forestry approached the management of the Forestry Enterprise with a proposal to completely entrust the carrying out of forestry work on this site to its care. In 2012, the Forestry Enterprise carried out thinning in the pine forest without observing the relevant rules and regulations and without agreement with the leadership of the School Forestry. Complaints have been made against the management of the Forestry Enterprise and regarding the financing of some school projects related to forest management work.

On the part of the village administration, it is necessary to improve work on the protection of natural monuments and unique biocenoses. Violators should be punished with fines and public censure at meetings of villagers. Cattle grazing in forested areas should be prohibited. After all, it was for the study, protection and renewal of forest resources, that the Berezka School Forestry was created at the Verkhnee Gakvari School.

Tsanatli Forest: This is a mixed birch-pine forest with an area of about 5 hectares. The plot is located opposite the village, at a distance of about $1 \mathrm{~km}$ south of the Gakvarinka River. The uniqueness of the site lies in that, together with the Litvinov birch, there is also the Caucasus endemic, the Radde birch. Rowan is also more common than in other forest areas. About 20 years ago, a section of the forest was almost completely cut down at this location by the management of the Forestry Enterprise, allegedly for the purpose of planting pine trees. However, the survival rate of pines was only $15-20 \%$ and, where once individual birch trees had been felled, they again multiplied as coppices with 5-8 trunks emerging from a single original. 
Due to overcrowded planting in shallow soil, some pines fell to one side when deep winter snow fell. The site is subject to intense anthropogenic impact - young pines and birches are often cut down by villagers for domestic needs. The site is located near a livestock route to alpine pastures. In Soviet times, the forest area adjacent to this route was fenced off with a metal mesh. However, when the pines had grown up, the protective netting was removed.

Protective measures undertaken: The management and members of the Edelweiss Eco-Group have carried out explanatory work on the need to protect and protect Radde birch from felling and the sustainable use of gifts of the forest and prevention of cattle grazing. The site is part of the forests allocated by the Forestry Enterprise for the Berezka School Forestry. By resolution of the head of the village administration, the Tsanatli area has been declared a natural monument of rural municipal importance.

Protective measures required: An important condition for the protection and protection of this natural object is strict observance of forestry legislation, observance of environmental norms and rules and observance of the rules for collecting medicinal raw materials. For this, it is necessary to carry out further explanatory work among the population through children's environmental organizations, the village administration and the Tsumadinskiy State Forestry Enterprise.

It is desirable that this site should become a base for carrying out student research work, for which the following actions should be undertaken:

- Fencing of the site on the side of the livestock route

- Development of a plan for the placement and arrangement of a mini-nursery for the cultivation of ornamental, rare and valuable species of trees and shrubs

- Undertaking of forest management work, including sowing seeds of pine and other species in bare places

- Development of a plan for an ecological trail including this section in order to promote environmental knowledge and mountain tourism.

The need to protect this area is also due to the fact that the villagers collect medicinal plants there. It is a favorite vacation spot and a base for excursions and practical primary school classes in nature, biology, geography and the world around us. Here students learn about characteristics of plants growing in this forest which have medicinal, aesthetic or scientific significance.

\section{Year of Ecology in Russia}

On 5 January 2016, Russian President Vladimir Putin signed a decree by which 2017 was declared the Year of Ecology in Russia. The purpose of this decision was to draw attention to the problematic issues existing in the environmental sphere and to improve the state of the country's environmental security. Thus 2017 was an important year for the Verkhnee Gakvari School

In the Verkhnee Gakvari School from the date of the announcement of the Year of Ecology, a plan for the year was drawn up, according to which teachers and students worked and achieved commendable results:

The Day of the Birds holiday was held, in which the students and the team took an active part.

Various All-Russian eco-lessons were held on the topics of:

- Waste management problems;

- Caspian-pearl of Dagestan;
- Protected places of Russia and Dagestan;

- Nature of the Caucasus;

- Guardians of Water.

Representatives of the school participated in various events, including:

- "Clean Rivers", where the banks of the Egdadinka River and the stream flowing to Ginkili were cleared with the schoolchildren.

- "Live Forest" and "Clean Forest".

- "All-Russian Day of Forest Planting".

- All-Russian ecological subbotnik "Green Russia", in which members of the Edelweiss Eco-Group and the Berezka School Forestry actively participated.

- All-Russian action "Let's Do It Together", where school students very actively participated in ongoing events: environmental lessons, brain-ring games, quizzes, ecological tales, activities, conversations, debates and class hours.

Two students of the school, Abdurahman $M$. Ismailov and Tavus M. Yakhyaeva, were winners in the regional stage of the competition "Ecoleader". Biology teacher, Shamil M. Ismailov, was the winner of this competition in the nomination for "Best Supervisor of an Educational Institution".

A school exhibition of drawings entitled "Take Care of Nature" was held, dedicated to the Year of the Environment and to respect for the nature of the village, district and republic.

Participation in various competitions of regional and republican significance, where school representatives achieved many first place and other commendable rewards:

- Regional competition "Green Planet".

- Regional competition "My Little Homeland".

- Regional competition "Young Researchers of the Environment" Regional competition "World Water Day".

- Regional competition "Teenager".

- Regional competition "Best School Forestry".

- Regional competition "Gardens Bloomed for Centuries".

- Regional competition "Educational and Experimental Site"

- Regional competition "Nature Connoisseurs".

- District quiz in Biology-Ecology.

- Regional competition "Young Amateur Photographers". Village".

- Regional competition "Living Symbol of the

- Regional competition "Natural Monuments of the Village and Region".

- Regional competition "Day of the Birds".

- Republican competition "Ecology in the Modern

World".

- Republican competition "Best Training and Experimental Site of an Educational Institution".

- Republican competition "Best School Forestry".

- Republican stage of the All-Russian competition "Let's Do It Together".

In the Republican stage of the Ecology-Quiz of the Ministry of Natural Resources, Dagestan, "Connoisseurs of Nature" 2015 the Edelweiss Eco-Group team won the Quiz Finalist Diploma.

Since the Year of Ecology 2016 and the 2017 conference in Agvali (see below), the Vekhnee Gakvari 
school and its teachers have continued to be active in various competitions, conferences, Olympiads. Their many awards include first places in:

- Regional stage of the Republican competition "Teacher of the Year of Dagestan" (2018).

- Regional stage of the competition "The Best Training and Experimental Site" (2018 \& 2019).

- Republican Olympiad of Biology Teachers Winner (2020).

- Regional stage of the competition "My Best Occupation" - Ismailov Shamil Magomedovich (2021).

- Interregional competition of works in design and research "Ecology of the Native Land" (2021).

Conferences organized by staff of the Verkhnee Gakvari School
The Verkhnee Gakvari School is providing a role model for organized public advocacy in the protection of the environment not only through its programmes which are focused on the participation of its students but through the energetic and dedicated engagement of its specialist staff in promoting these issues in the broader district and republican forums.

In 2010, a scientific and practical conference on ecology was held at the school, with the participation of many specialists from Makhachkala and the mountainous regions of Dagestan. This conference was followed in 25-26 October 2017 by the organization of the Scientific-Practical Conference, "Ecology of the Mountain Territories of Dagestan: Problems and Pathway to Their Solution" in the Tsumadinskiy administrative centre of Agvali. Project director was Magomed Magomedov Ismailov, Director of the Verkhnee Gakvari School (Fig. 52).

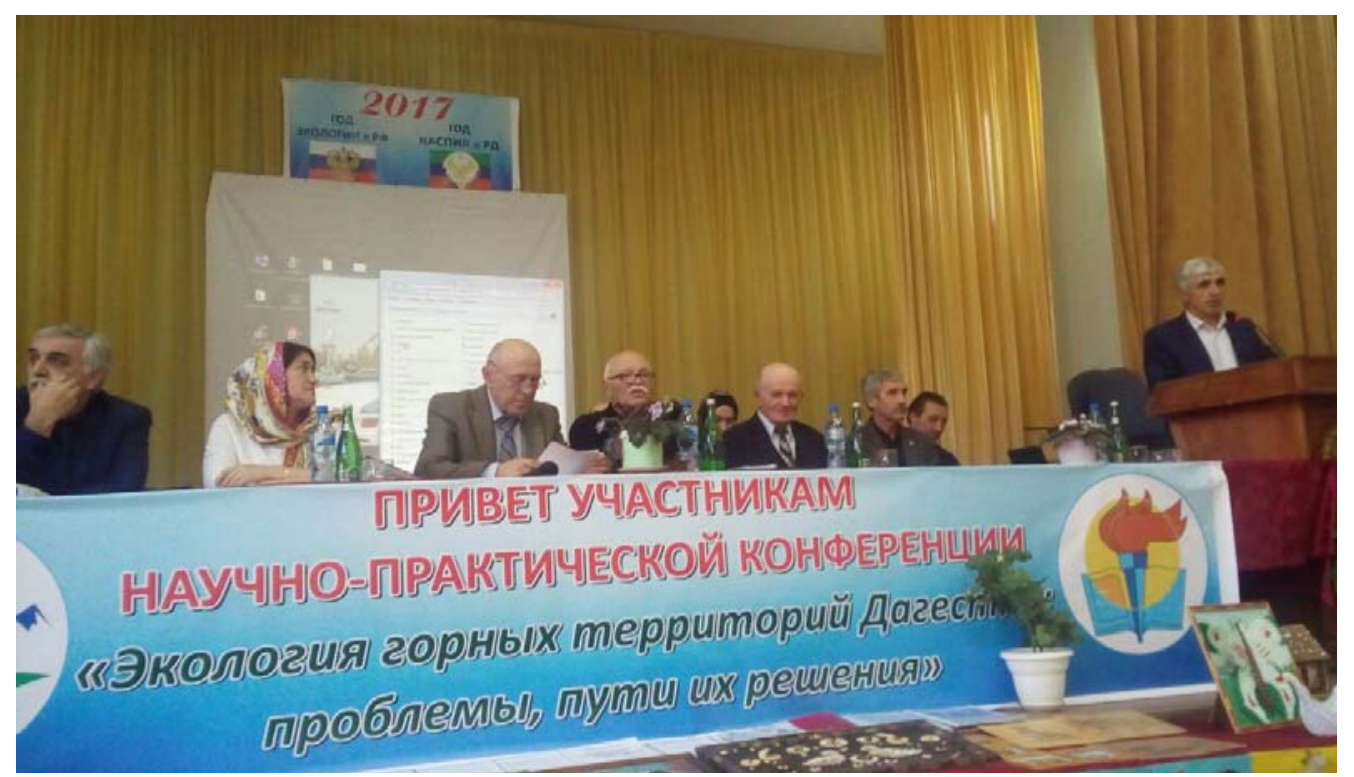

Figure 52. Magomed Ismailov, Director, Verkhnee Gakvari School, addressing the 2017 Conference on the Ecology of the Mountain Regions of Dagestan: Problems and Pathway to their Solution

Participating were guests from Makhachkala and speakers and representatives from four mountain districts (Akhvakhsky, Gumbetsky, Botlikhsky and Tsumadinskiy). The plenary session, was led by Prof. Gairbeg $M$. Abdurakhmanov, Director, Institute of Ecology and Sustainable Development, Dagestan State University and President Regional Section, Republican Ecological Party "Zelenie" (Green). Papers were presented on the following issues:

- Gairbeg M. Abdurakhmanov - "Saving for our Descendents" means to preserve the genofond of wildlife and biogeocomplex of the high mountains.

- Zagir V. Ataev - "Nature conservation in the territory of high mountain Dagestan and perspectives for its development".

- Yuriy A. Yarovenkov - "Large mammals of the Andiiskoe Koisu river basin".

- Magomed G. Magomedov - "Ecologicalgeographical risk factors for youth of the mountain territories of Dagestan".

- Makagadzhi E. Idrisov \& Ramazan A. Murtazaliev - "Rare and disappearing types of vegetation of south-west Dagestan and problems of their preservation".
- Ali Dzh. Khakibov \& Idris A. Idrisov - "Landslide phenomena in high mountain Dagestan".

- Feizula M. Feiziev - "Health of the environment - health of the nation".

- Rustam A. Khalilov \& Labazan Kh. Magomedov - "Ecological problems of the mountainous part of Dagestan - its particularities and pathway to a solution".

- Magomed I. Rasulov, Bariat M. Gadzhieva \& Magomed R. Rashidkhanov - "Water supply problems of the inhabitants of the mountain territories".

Within the framework of the conference a scientific research work competition was held between students and teachers of four mountain districts of the republic, reflecting the environmental problems of mountain Dagestan with recommendations for protection and preservation of nature.

At the conclusion of the conference participants resolved to conduct the next scientific-practical conference on the regional level in 2020.

In analysing current questions associated with the present state of the environment and utilisation of the natural resources of the mountain territories of Dagestan, the conference participants recommended the following: 2017 Conference Resolutions: 
1. District Councils and Administrations of the Mountain Territories of Dagestan:

- Formulate and agree on a plan of environmental measures in the light of contemporary demands.

- Organise separate collection of solid household waste in organisations and institutions of municipalities.

- Consider the possibility of attracting honest investors for the implementation of environmental projects aimed at reducing negative impacts on the environment.

- Identify and describe specially protected natural objects of the region.

- Develop a system of public ecological monitoring of the state of the environment.

- Provide advanced training for heads of institutions and organizations on compliance with sanitary and environmental norms and regulations.

2. Cultural and Tourism Sector

- Formulate ecological-touristic trails with the aim of attracting and informing tourists about the wealth of plant and animal life of the mountain districts of Dagestan.

- Organise a social publicity campaign directed at a caring attitude to nature necessary for the conservation of rare species and unique vegetation communities.

3. Forestry Management:

- Strengthen the interaction of district administrations between law enforcement agencies, district and village administrations and public organizations regarding the prohibition of land pollution by solid household wastes.

- Create an effective system of interaction between governmental executive authorities and forestry departments for fire safety.

- Conduct an inventory of forest areas classified as specially protected natural areas.

- Organise work to clamp down on the unauthorized dumping of rubbish in forest reserves.

- Include in the work plan activities to identify forests of special natural value which are habitats for rare species of plants, animals and birds.

- Continue work to increase the area under nursery plantings and the growing of rare and ornamental forest species.

- Continue work on expanding the network of school forestries based in educational institutions. 4. Rural municipalities:

- Ensure work is undertaken on the collection and disposal of solid household waste, taking into account the requirements of official sanitary regulations and norms.

- Ensure research is undertaken aimed at the establishment of Specially Protected Natural Areas and their conservation status.

- In cooperation with forestry departments and within the framework of environmental measures, expand the forest plantings along the banks of small rivers and streams to strengthen them.

- As a component of environmental campaigns, undertake subbotniks to clean up garbage and debris from the banks of small rivers, including places of mass recreation.

- Promote work on the promotion of environmental knowledge and the involvement of both the adult population and youth in environmental conservation and educational activities.

\section{Educational organizations:}

- In the Year of Ecology and the Caspian, continue work on the creation and protection of specially protected natural areas of local importance.

- Direct the activities of school environmental organisations to implement children's research projects focused on biodiversity conservation, sustainable development of mountain ecosystems and protection of natural habitats.

- For the purpose of environmental education and enlightenment of adolescents, promote the development of children's ecological tourism, expeditionary and excursion activities.

- Develop and create ecological, geological and local history routes.

- Strengthen career guidance activities aimed at promoting professions related to ecology, biology, geography, wildlife conservation and environmental conservation, taking into account interaction with social partners.

- To cover the activities of schoolchildren of the mountain zone in the mass media, on school websites and internet resources.

- Summarize experience in the implementation of research, environmental and educational projects in the mountain zone at scientific and practical conferences and seminars.

- Foster the interaction of public educational organisations with higher and secondary educational institutions specialising in the field of environmental protection.

\section{Engagement of the Verkhnne Garvari School with the} broader village community

Through all its activities in protecting the natural environment the school has become the socio-cultural centre of the village of Verknee Gakvari. One of the important achievements of its environmental organizations has been the identification, description and protection of specially protected natural objects of rural importance.

The protection of the village's water bodies from pollution and the study of various types of waters and identification of their significance for human health are other important directions of the school's environmental organizations, which have identified the chemical composition of almost 50 water sources in the village and district.

Further prospects for the development of environmental knowledge are also important. An agreement on joint activities has been concluded with:

- Dagestan Institute for the Development of Education (DIRO)

- Institute of Ecology and Sustainable Development of Dagestan State University

- Dagestan State University.

One of the results of such activities has been the annual admission of students to faculties of natural sciences in state institutions of higher learning.

Constant and persistent promotion of environmental knowledge is bearing fruit. Students and teachers are increasingly involved in environmental protection. Students have been the winners of the regional stage of the All-Russian action "Let's Do It Together". 
The joint work of the school and the village administration currently focuses on the problem of collection and disposal of household waste.

The school is also the centre of anti-drug and antiterrorist activities in the community. As a result of vigorous work in raising awareness, it has been possible to drastically reduce the number of smokers and consumers of alcoholic beverages among the villagers. Extensive campaigning work is carried out in this direction at the school: in class hours, debates, conferences and thematic lessons.

Schoolchildren and all participants in the educational process are involved in useful environmental activities: the area around the school and kindergarten and individual locations in the settlement continue to be improved and greened. On the occasion of the 70th anniversary of the Victory in the Second World War, students planted birch seedlings in honour of their grandfathers, grandmothers, relatives, participants and veterans of the war and home front.

Members of school environmental organizations and the school administration intend to carry out further work on the introduction of rare and endangered plant species within the school facilities.

\section{Major Environmental Issues of Current Concern to the Community of Verkhnee Gakvari}

As elaborated above, throughout its existence almost all that was required to feed, shelter and support the subsistence activities of the Verkhnee Gakvari community have been derived locally or traded in from neighbouring regions and had no detrimental effect on the environment and harmoniously exploited its potential. No pesticides or chemical fertilisers are needed or used. The villages make liberal use of cow manure on their fields, which not only serves as a fertilizer but serves to condition clayey soils making them easier to till. However, sheep and cattle are annually vaccinated by government veterinarians following brucellosis outbreaks. Members of the community are legally masters of their own lands and there are no erosion

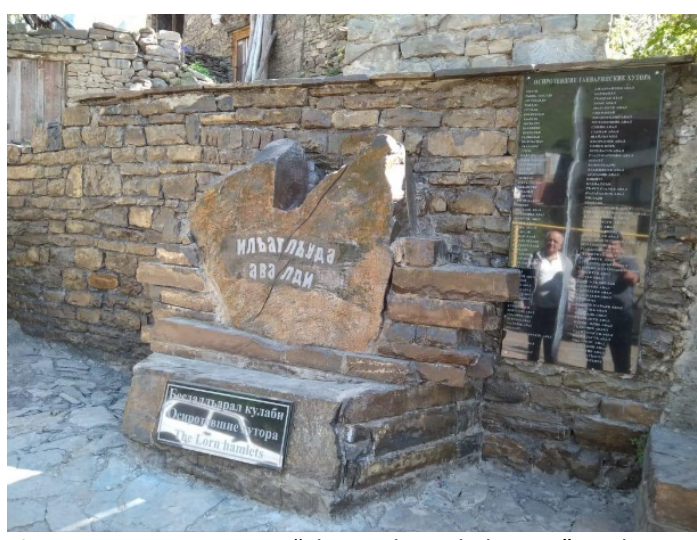

Figure 53. Monument to "The Orphaned Khutora", Nizhnee Gakvari

The limited domestic incomes in Verkhnee Gakvari today encourage through necessity the perpetuation of the community's ago-pastoral subsistence traditions and the wise use of natural resources. Monies earned by inhabitants of its diaspora working outside the district are being productively reinvested in repairing or building homes to standards now considered desirable. or land degradation problems, such as have occurred through overgrazing and unwise land-clearing in the Transcaucasus to the south. Today Verkhnee Gakvari still has a primarily subsistence economy. Monies earned by villages by working outside the district are being reinvested in repairing or building homes to standards considered desirable today, which brings with it wastewater problems (see below).

It should be emphasized that the agro-pastoral territory in the valley settled by the Gakvarians never sustained a large population. Though nuclear families were large by today's standards, there were not many of them. A detailed Russian ethnographic map of the peoples of Dagestan showing the Andiiskoe Okrug numbers a total of 3,883 Chamalals across all its villages, while a 1927 Soviet tabulation listing all villages and khutora in the Okrug gives a total of 3,397 Chamalals of whom 191 lived in Verkhnee Gakvari, not including its khutora. (All-Union population census of 1926 in the Dagestan ASSR). The All-Russian population census of 2010 gives the population of the village itself as 378 . It classifies them as Avars.

Largely overlooked in the story of the long-lived agro-pastoral communities of the upper Andisskoe Koisu is the significance of the role played by the many khutora on the periphery of their territories. There are those who lament their forced closure and abandonment in the Soviet period as a loss of valuable contributors to socio-ecological product viability and richness of the region, just as the agricultural richness of Tuscany in Italy, for instance, would be affected if the fertile hill farms between its towns and villages were forcibly closed. The carefully tended khutora often occupied prime parcels of land in ecological favorable locations in the landscape with their own springs and good soils and were often the property of the richest families.

In 2018, Magomed Abdulhabirov with others erected a monument to "The Orphaned Farms of Dagestan" in Nizhnee Gakvari on which are recorded the names of all known abandoned khutora in Gakvarin territory [76] (Fig. 53, 54).

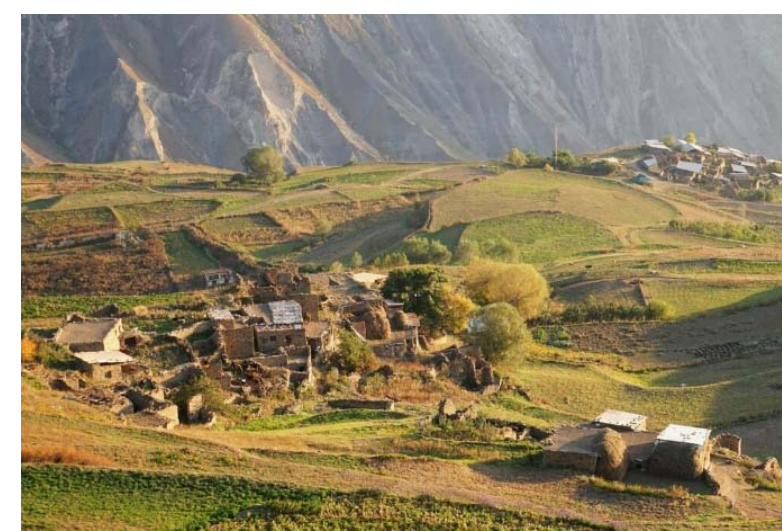

Figure 54. Khutora adjacent to Chamalal settlement of Gigatli. Abandoned during Soviet period but now re-used. Etnomix

As an outcome of many decades of the school's engagement in issues relating to environmental management, most of the Verkhnee Gakvari community is now highly sensitized and informed about issues affecting the local environment and have identified the following has requiring critical attention in preserving the character and function of its socio-ecological production system: 
Effective waste management and sanitation - the dilemma of how to manage both liquid and solid wastes - is today the major concern of the community in sustaining a healthy environment.

With the introduction of modern expectations of norms of living in houses in the community and the recent provision of gas and electrical services, houses are increasingly fitted with washing machines and bathrooms. These collectively produce large volumes of waste water and sewage and environmentally harmful chemicals which end up untreated in the territory's natural drainage system. This further adds to the pollution of the waters of the Andiiskoe Koisu, already burdened with waste from other valley communities.

Domestic solid waste, particularly of plastics, is creating an ever-growing problem with the village not being served by a government waste collection service (as exists in the nearby district administrative capital of Agvali) and waste is just being tossed in a municipal dump or over a road side without any further processing (as is also happening elsewhere in the district) where the wind blows some of it further and disfigures the pristine natural landscape. In the absence of a government initiated and funded central sewage treatment facility and sanitary solid waste disposal system, members of the community themselves are now discussing how they may themselves undertake this complex task.

Dagestan State University and Verkhnee Gakvari: Contribution to Regional Collaboration and AwarenessRaising of the Role of Environmental Management in Sustainable Development

To better understand the whole range of issues involved in the sustainable habitation and development of communities like Verkhnee Gakvari, and as an outcome of the resolutions of the 2017 Conference, "Ecology of the Mountain Territories of Dagestan: Problems and Pathway to Their Solution", the Institute of Ecology and Sustainable Development of Dagestan State University is collaborating with the Verkhnee Gakvari School in the formulation of the initiative entitled, "Conserving the Koisu: Sustaining the Mountain Fastness of the Upper Andiiskoe River - A Uniquely Surviving Socio-Ecological Continuum in the Dagestan Caucasus".

To this end the Caspian Centre for the Protection of Nature of the Institute of Ecology and Sustainable Development, Dagestan State University (DSU), in partnership with communities of the Tsumadinskiy District of the Republic of Dagestan and with the endorsement and support of the relevant republican and federal agencies, are implementing a community-centred programme to record, conserve, promote and sustainably exploit the heritage resources of the headwaters region of the Andiiskoe Koisu as the basis for much-needed income generation for the region's population.

This programme is one of an inter-related suite of planned initiatives emanating from the newly-created Dagestan-Qatar Scientific-Educational Centre at Dagestan State University. It is being undertaken in commemoration of the $100^{\text {th }}$ anniversary of the declaration of the Dagestan Autonomous Soviet Socialist Republic (DASSR) and is being implemented within the framework of the concepts of the International Partnership for the Satoyama Initiative.

Within the framework of regional, republication and national environmental conservation and sustainable development objectives, the Conserving the Koisu programme aims to:

- Enhance regional awareness of in the natural environment and the valorization of the region's unique and deep history identity and of the needs and potential benefits of conserving and reviving productive socioecological relationships in the face of negative anthropogenic impacts.

- Contribute to the articulation of initiatives to underpin the Tsumadinskiy District's development in terms of income and revenue generation opportunities, by ensuring that any use of natural resources is equitable and sustainable.

The programme will build on regional initiatives which have already been undertaken to protect and sustainably develop the ecological resources of the region, in large part arising from the dedicated collaborative work of the Tsumadinskiy District administration and the specialist ecological and biological competencies of the School of the settlement of Verkhnee Gakvari which have already resulted in two major government-supported conferences dedicated to these issues in the Tsumadinskiy and neighbouring high mountain districts.

2021-2023: The first phase of the programme is one of intensive district-wide multidisciplinary scientific research into relevant aspects of the regional natural environmental and tangible and intangible cultural heritages and their conservation needs. Existing data about the district and neighbouring region, both published in the scientific literature and the rich as-yet unpublished information developed by scholars in local communities, will be reviewed and systematized as a basic internetaccessible programme resource.

2024-2025: On the basis of the information gathered in the first phase, proposals will then be developed for the subsequent phase to advance specific concrete pilot projects directed at creating a methodological basis for implementing the core programme objectives at the district level. It is expected that such projects would include:

- A comprehensive eco/cultural tourism initiative building on local expertise generated during the Soviet period and on the existence of alpine tourist accommodation facilities near Agvali (which could also be used for summer residential eco/heritage courses, as well as to accommodate programme researchers).

- A visitor information centre in the district administrative centre of Agvali with an online informational website, utilizing the commitment and expertise already evidenced by the internet and Youtube contributions of local citizens in promoting the region.

- Extension of regional heritage designation: assessment and listing of local municipal district natural and architectural heritages.

- Conservation and restoration (in physical and in virtual form) of nationally and regionally-significant historical monuments and built environments, such as the fire-ravaged mosque and abandoned settlement of Khushtada and the largely intact but disused village and farmlands complex of Stari Gigikh. Such a project would include the detailed mapping and documentation of a living community in its traditional architectural setting such as preserved in Kvanada and Tindi.

- Comprehensive district project to restrict and remove waste defiling the Andiiskoe Koisu and its tributaries. 
- Selection of a specific settlement for implementation of a pilot holistic eco-community approach including a comprehensive waste water and refuse management system to serve as a model for other communities in the Tsumadinskiy District and elsewhere in Dagestan.

- Implementation of a genofond research and preservation programme into regionally adapted horticultural and cereal plant types and livestock (cattle) breeds (as has recently been achieved for the Dagestan mountain sheep breed).

- Support and participation in the field study of the six now endangered local languages which is being undertaken by the Linguistic Convergence Laboratory of the Institute of Higher Economic Studies, National Research University, Moscow.

- Traditional water mill documentation and conservation/sustainability project.

- Development and promotion of a range of traditional organic food products, officially registered as regionally specialties, for the republican and national gourmet market.

- Development and implementation of a Regional Ecological Awareness and Tourist Guide Education Circle in local schools on the basis of the model for forestry conservation established at Verkhnee Gakvari School.

- On the basis of a survey and assessment of human resources roles critically needed in the region, develop strategies to educate local youth to fill them (including identifying and pursuing the creation of republican and national scholarships to provide the appropriate educational opportunities required).

- Extension of regional heritage designation: assessment and listing of local municipal district natural and architectural heritages.

- Support for existing local tourism development initiatives, such as that formulated by the community of Tlondoda.

- Publication by both local and non-local scholars in scientific journals and monographs of works relating to the heritages and sustainability research outcomes of the Tsumadinskiy District arising from Conserving the Koisu programme activities.

Longer term potential outcomes of the programme could be the nomination of the headwaters region of the Andiiskoe Koisu as a region of global significance to mankind as a: category);

- UNESCO World Heritage site (cultural landscape

- Geopark (Global Geoparks Network);

- UNESCO Biosphere Reserve.

The programme is led by Professor Guy Petherbridge, Director, Caspian Centre for Nature Preservation of Dagestan State University's Institute of Ecology and Sustainable Development in close consultation with representatives of regional communities and stakeholders who have been actively engaged in researching and supporting their region's heritage resources for many years. Almost every community in the district is notable for the activity of dedicated, enthusiastic and highly educated local specialists in a range of disciplines and interests who will constitute a fundamental programme resource.

The programme will also draw on a range of international and regional (i.e. Caucasus, Caspian) collaborative scientific and institutional resources in related disciplines, particularly those concerned with research into mountain environments and the sustainability of mountain communities, such as those of the International Union for the Conservation of Nature. These include those undertaken in the European Alps and the Transcaucasus and particular in adjacent Georgia, where substantial advances have been made in developing nature conservation and heritage tourism based on specialist research in the Andiiskoe Koisu source waters province of Tusheti. The programme will also draw on related initiatives in states of the high-altitude south-facing macroslopes of the Himalayas, whose environments and traditional agro-pastoral systems have many remarkable similarities with those of the Tsumadinskiy and neighbouring high mountain regions in Dagestan.

\section{DISCUSSION}

This case study has enabled a fuller understanding of the achievements of the Chamalal Verkhnee Gakvari community in preserving its natural environment and cultural landscape, largely through the wisdom and energies of its school's teaching staff. The study process has already engendered considerable support for its objectives from state environmental protection and educational authorities.

The study indicates (a) the degree to which certain traditional rural communities in the Dagestan high Caucasus which continue the multi-generational use of their lands are knowledgeable about the nuances of the natural environments which sustains them and (b) the positive role which community consensus through adat and structured education of children play in the sustainable use of their environment and natural resources.

\section{CONCLUSION}

Together the village of Verkhnee Gakvari and other communities of the upper Andiiskoe Koisu present a unique cultural continuum in which evidences of its principal evolutionary phases remain accessible to scientific and historical research in the form of perpetuations of ancient life style practices, settlement patterns and built structures, material culture, agro-diversity and plant adaptation, animal resource utilization, customs and beliefs (polytheism transitioning to Christian and then Islamic monotheism), linguistic "islands", etc. In essence we have before us a largely unexplored and undisturbed, living laboratory of human societal engagement with the natural environment. This remarkable continuity is of global significance for understanding the evolution of human society and presents a unique survival in Europe of successful and harmonious socio-ecological interdependencies.

The community of Verhnee Gakvari in the highlands of the Tsumadinskiy District of the Republic of Dagestan has demonstrated how over untold centuries a succession of dedicated systems of shared community mores, religious beliefs and public education has equipped its members to engage purposefully in managing the interdependencies of man and the natural world and has contributed to the longevity and continuing preservation of one of the world's most intact socio-ecological production landscapes.

As the combined impacts of modern society and climate change now inevitably impinge upon the ability of the inhabitants of this ancient homeland to sustain the benefits which they have so successfully learned to craft 
from their environment throughout millennia, the region is in priority need of national and international recognition and support.

\section{ACKNOWLEDGMENT}

The authors are grateful to Abubakar M. Ismailov, a native of Verkhnee Gakvari and Director, Thin Film Laboratory, Faculty of Physics, Dagestan State University, for providing constant support in facilitating fieldwork and in sourcing photographic images for the project. Yusup G. Yusupov and Marat N. Pirbudagov provided valuable typographic and electronic formatting assistance in production of the published article.

\section{REFERENCES}

1. Atayev Z.V. Recent glaciation of Bogossky Range. Dagestan State Pedagogical University. Journal. Natural and Exact Sciences, 2018, vol. 12, no. 2, pp. 62-74. (In Russian) DOI: 10.31161/1995-0675-2018-12-2-62-74

2. Abikh G.V. Issledovaniya nastoyashchikh i drevnikh lednikov Kavkaza [Research of the present and ancient glaciers of the Caucasus]. In: Collection of information about the Caucasus. Tiflis, 1871, vol. 1, pp. 85-126. (In Russian) 3. Alejnikov A.A., Lipka O.N. Tayushchie gory Dagestana [Melting Mountains of Dagestan]., Moscow, The World Wildlife Fund (WWF), 2016, 108 p. (In Russian)

4. Ataev Z.V. The landscapes of the highland Dagestan and their current condition. Izvestiya Dagestanskogo gosudarstvennogo pedagogicheskogo universiteta.

Estestvennye i tochnye nauki [Proceedings of Dagestan State Pedagogical University. Natural and Exact Sciences]. 2007, no. 1, pp. 90-99. (In Russian)

5. Ataev Z.V. Highlands orography of the Eastern Caucasus. Geograficheskii vestnik [Geographical Bulletin]. 2012, no. 2, pp. 4-9. (In Russian)

6. Budagov B.A. Modern and ancient glaciation of the Eastern part of the Greater Caucasus (according to new data). Doklady AN ASSR [Reports of the Academy of Sciences of Azerbaijan SSR]. 1958, no. 2, pp. 119-123. (In Russian) 7. Znamenskaya O.M. [Glaciation of the Bogossky Range. The Caucasus, Glacial areas]. In: Trudy lednikovykh ekspeditsii [Proceedings of Glacial Expeditions]. Leningrad, 1936, pp. 1661. (In Russian)

8. Kovalev P.V. On the ancient glaciation of the Eastern Caucasus. Vestnik Khar'kovskogo universiteta. Seriya «Geografiya» [Proceedings of Kharkov University, Ser. Geogr.]. 1964, iss. 1, no. 2. (In Russian)

9. Magomedov A.M., Ataev Z.V. [The influence of orography on the climatic conditions of Bogossky mountain range in the Eastern Caucasus]. In: Trudy Geograficheskogo obshchestva Respubliki Dagestan [Proceedings of the Geographical Society of the Republic of Dagestan]. 2005, iss. 33, pp. 164-165. (In Russian)

10. Panov V.D., Il'ichev Yu.G., Salpagarov A.D. Kolebaniya lednikov Severnogo Kavkaza za XIX-XX stoletiya [Fluctuations of the Northern Caucasus glaciers for the XIX-XX centuries]. Pyatigorsk, 2008, 330 p. (In Russian)

11. Panov V.D. Evolyutsiya sovremennogo oledeneniya Kavkaza [Evolution of the Caucasus glaciation]. St. Petersburg, Gidrometeoizdat Publ., 1993, 429 p. (In Russian)

12. Piotrovich V. V. [Melting and runoff from the glaciers of Addala-shukhgel' in Dagestan]. In: Trudy lednikovykh ekspeditsii [Proceedings of Glacial Expeditions]. Leningrad, 1936, iss. 5, pp. 76-106. (In Russian)
13. Amirkhanov Kh.A. Chokhskoe poselenie: chelovek i ego kul'tura v mezolite i neolite gornogo Dagestana [Chokh settlement: man and his culture in the Mesolithic and Neolithic of mountainous Dagestan]. Moscow, 1987, 224 p. (In Russian) 14. Murtuzaliev R.A. Biologiya Tsumadinskogo raiona [Biology of Tsumadinsky region]. Available at: http://www.tsumada.ru/ru/text/41 (accessed 03.06.2021) 15. Coudreau M. "A healthy mountainous island surrounded by a sea of malaria": Ecology and War in the Caucasus. Environment \& Society Portal, 2021, no. 4. DOI: $10.5282 / \mathrm{rcc} / 8381$

16. Karafet T.M., Bulayeva K.B., Nichols J., Bulayev O.A., Gurgenova F., Omarova J., Yepiskoposyan L., Savina O.V., Rodrigue B.M., Hammer M.F., Coevolution of genes and languages and high levels of population structure among the highland population of Dagestan. Journal of Human Genetics, 2016, vol. 61, iss. 3, pp. 181-191. DOI: 10.1038/jhg.2015.132 17. Yunusbayev B., Metspalu M., Jarve M., Kutuev I., Rootsi S., Metspalu E. et al. The Caucasus as an asymmetric semipermeable barrier to ancient human migrations. Molecular Biological Evolution. 2011, iss. 29, pp. 359-365. 18. Bulaeva K.B., Dubinin N.P., Shamov I.A., Isaichev S.A., Pavlova T.A. Population genetics of Dagestan highlanders. Genetika [Russian Journal of Genetics]. 1985, iss. 21, pp. 17491758.

19. Balanovsky O., Dibirova K., Dybo A., Mindrak O., Frolova S., Pocheshikova E. et al. Parallel evolution of genes and languages in the Caucasus region. Molecular Biological Evolution, 2011, vol. 28, iss. 10, pp. 2905-2920. DOI: $10.1093 / \mathrm{molbev} / \mathrm{msr} 126$

20. Bulayeva K.B., Davudov O.M., Pavlova T.A., Kurbanov R.D., Bulayev O.A., Harpending H. et al. Genetic subdivision of Dagestan ethnic populations. Russian Journal of Genetics, 2003, vol. 39, iss. 1, pp. 68-76. DOI:

10.1023/A:1022027028666

21. Bulayeva K.B., Jorde L.B., Ostler C., Watkins S., Bulayev O., Harpending H. et al. Genetics and population history of Caucasian populations. Human Biology, 2003, vol. 75, no. 6, pp. 837-853. DOI: 10.1353/hub.2004.0003

22. Bulayeva K.B., Jorde L., Watkins S., Ostler C, Pavlova T.A., Bulayev O.A. Ethnogenomic diversity of Caucasus, Dagestan. American Journal of Human Biology, 2006, iss. 18, pp. 610-620. DOI: DOI 10.1002/ajhb.20531

23. Marchiani E.E., Watkins W.S., Bulayeva K., Harpending H.C., Jorde L.B. Culture creates genetic structure in the Caucasus: autosomal, mitochondrial and Y-chromosomal variation in Daghestan. BMC Genetics, 2008, vol. 9, no. 47. https://doi.org/10.1186/1471-2156-9-47

24. Nasidze I., Risch G.M., Robichaux M., Sherry S.T., Batzet M.A., Stoneking M. Alu insertion polymorphisms and the genetic structure of human populations from the Caucasus. European Journal of Human Genetics, 2001, vol. 9, iss. 4, pp. 267-272. DOI: 10.1038/sj.ejhg.5200615

25. Nasidze I., Sarkisian T., Kerimov A., Stoneking M. Testing hypotheses of language replacement in the Caucasus: evidence from the Y-chromosome. Human Genetics, 2003, vol. 112, iss. 3, pp. 255-261. DOI: 10.1007/s00439-002-0874-4 26. Tofanelli S., Ferri G., Bulayeva K., Caciagli L., Onofri V., Taglioli L. et al. J1-M267 Y lineage marks climate-driven prehistorical human displacements. European Journal of Human Genetics, 2001, vol. 17, iss. 11, pp. 1520-1524. DOI:

10.1038/ejhg.2009.58

27. Caciagli L., Bulayeva K., Bulayev O. et al. The key role of patrilineal inheritance in shaping the genetic variation of Dagestan highlanders. Journal of Human Genetics, 2009, vol. 54, pp. 689-694. DOI: 10.1038/jhg.2009.94 
28. Takeuchi K. Rebuilding the relationship between people and nature: the Satoyama Initiative. Ecol Res, 2010, vol. 25, pp. 891-897. DOI: 10.1007/s11284-010-0745-8

29. Getseu V.V. Mineral'nye istochniki Dagestana i ikh lechebnoe znachenie [Mineral springs of Dagestan and their medicinal value]. Makhachkala, Dagestan book Publ., 1976, 32 p. (In Russian)

30. Andiickii okrug [Andean District]. Available at: http://ethno-kavkaz.narod.ru/andi26.html (accessed 20.06.2021)

31. Gulisashvili V.Z., Makhatadze L.B., Prilipko L.I. Rastitel'nost' Kavkaza [Vegetation of the Caucasus]. Moscow, Nauka Publ., 1975. (In Russian)

32. Taysumov M.A., Umaeva A.M., Abdurzakova A.S., Israilova S.A., Astamirova M.A.-M., Shahgireeve Z.I., Magamadova R.S., Umarov R.M. Istoriya formirovaniya i puti proniknoveniya reliktovoi dendroflory $v$ Chechnyu i sopredel'nye territorii [The history of formation and ways of penetration of the relict dendroflora into Chechnya and adjacent territories]. International Conference on Smart Solutions for Agriculture (Agro-SMART 2018), Atlantis Press, Advances in Engineering Research, col. 151, pp. 958-962. (In Russian)

33. Movchan G.Ya. Staryi avarskii dom v gorakh Dagestana $i$ ego sud'ba [Old Avar house in the mountains of Dagestan and its fate]. Moscow, 2001, 525 p. (In Russian)

34. Ajmone-Marsa P., Garcia J.F., Lenstra J.A. On the origin of cattle: how aurochs became cattle and colonized the world. Evolyutsionnaya antropologiya [Evolutionary Anthropology]. 2010, iss. 19, pp. 148-157. (In Russian)

35. Bollongino R., Burger J., Powell A., Mashkour M., Vigne J.D., Thomas M.G. Modern taurine cattle descended from small number of Near-Eastern founders. Molecular Biology and Evolution, 2012, vol. 29, iss. 11, pp. 2101-2104. DOI: $10.1093 / \mathrm{molbev} / \mathrm{mss} 092$

36. Bradley D.G. Genetics and origins of domestic cattle. In Documenting Domestication. New Genetic and Archaeological Paradigms. Zeder, M.A., Bradley, D.G., Emshwiller, E. and Smith, B.D. (eds), University of California Press, Berkeley, 2006, pp. 317-328.

37. Felius M., Koolmees P.A., Theunissen B., European Cattle Genetic Diversity Consortium, Lenstra, J.A. On the breeds of cattle - historic and current classifications. Diversity, 2011, vol. 3, iss. 4, pp. 660-692. DOI: 10.3390/d3040660

38. Zeder M.A., Emshwiller E., Smith B.D., Bradley D.G. Documenting domestication: the intersection of genetics and archaeology. Trends in Genetics, 2006, vol. 22, iss. 3, pp. 139155. DOI: 10.1016/j.tig.2006.01.007

39. Ozdemirov A.A., Chizhova L.N., Khozhokov A.A., Surzhikova E.S., Dogeev G.D., Abdulmagomedov S.S. Polymorphism of genes CAST, GH, GDF9 of sheep of the Dagestan mountain breed. South of Russia: ecology, development, 2021, vol. 16, no. 2, pp. 39-44. (In Russian) DOI: 10.18470/1992-1098-2021-2-39-44

40. Ramazanova Z.B. Hunting among the peoples of Dagestan in the 19th - early 20th centuries. Acta Historica: Works on History, Archeology, Ethnography and Social Science, 2019, vol. 2, no. 2, pp. 26-44. DOI: 10.24411/2658-3836-2019-10018 41. Peterbridge G. Proizvodstvo glavnykh produktov gornoi zhizni: Razmyshleniya ob islame, agrotekhnologiyakh i ekologii na Kavkaze i v Zakavkaz'e [Manufacturing the Main Products of Mountain Life: Reflections on Islam, Agrotechnology and Ecology in the Caucasus and Transcaucasia]. As-Salam, October 2019. (In Russian)

42. Petrova N.L., Terekhov Ya.P., eds. Narody Dagestana [People of Dagestan]. Moscow, Nauka Publ., 1997, pp. 222230. (In Russian)
43. Moseley C. Atlas of the World's Languages in Danger, $3^{\text {rd }}$ ed., Paris, UNESCO Publishing, 2010. Available at:

http://www.unesco.org/culture/en/endangeredlanguages/atl as (accessed 05.06/2021)

44. von Erckert R. Die Sprachen des kaukasischen Stammes. Wien: Hölder. 1895, vol. 6.

45. Dirr A. [Materials for studying of languages and dialects of Andic-Dido group]. In: Sbornik materialov dlya opisaniya mestnostei i plemen Kavkaza [Collection of Materials for the Description of the Territories and Peoples of Caucasus]. Tbilisi, 1909, vol. 40. (In Russian)

46. Bokarev A. Ocherki grammatiki chamalinskogo yazyka [Essays on the grammar of the Chamalin language]. MoscowLeningrad, 1949. (In Russian)

47. Magomedbekova Z.M. [Chamalin language]. In: Yazyki narodov SSSR. Iberiisko-kavkazskie yazyki [Languages of the peoples of the USSR. Iberian-Caucasian languages]. Moscow, 1967, vol. 4, 713 p. (In Russian)

48. Roncero K. An audio-visual documentation of Chamalal, a language of Dagestan (Russia). Preservicar/ELAR. Available at: https://elar.scar.ac.uk/collection/MPI1234834 (accessed 27.05.2021)

49. Seferbekov M. Notes on mountain cults in Dagestan. Iran and the Caucasus, 2016, vol. 20, iss. 2, pp. 215-218. DOI: 10.1163/1573384X-20160205

50. von Petzinger G. The First Signs: Unlocking the Mysteries of the World's Oldest Symbols. Atria Books (Simon and Schuster), New York, 2017, 307 p.

51. Kotovich B.M. Opyt klassifikatsii drevnikh pisanii gornogo Dagestana [Experience of classification of ancient scriptures of mountainous Dagestan.]. 1974, pp. 29-49. (In Russian) 52. Islammagomedov A. Avartsy: Istoriko-etnograficheskoe issledovanie XVIII-nach. XX v. [Avars: Historical and ethnographic research of the XVIII-early XX century]. Makhachkala, 2002, pp. 64-92. (In Russian)

53. Abakarov A.I., Davudov O.M. Arkheologicheskaya Karta Dagestana [Archaeological Map of Dagestan.]. Moscow, 1993, 189 p. (In Russian)

54. Mian H.S., Janas Khan J., ur Rahman A. Environmental Ethics of Islam. Journal of Culture, Society and Development. 2013, vol. 1, pp. 69-74.

55. An Islamic Toolkit on Forest Protection: Resources for Religious Leaders and Communities. The Interfaith Rainforest Initiative, UN Environment Programme, 2019.

56. Bakar O. Environmental Wisdom for Planet Earth: The Islamic Heritage. Centre for Civilizational Dialogue, Kuala Lumpur, University of Malaya Press, 2007.

57. Bhatti E.A. The Holy Quran on Environment. Brennan, Lahore, Royal Book Company, 2009.

58. Deen M.Y. The Environmental Dimensions of Islam. The Lutterworth Press, 2000.

59. Gottlieb R.S. This Sacred Earth: Religion, Nature and Environment, Routledge, New York \& London, 2003. 60. Izzi Deen (Samarrai) M.Y. Islamic Environmental Ethics: Law and Society, in Engel J.R \& Engel J.C. (eds), Ethics of Environment and Development, London, Bellhaven Press, 1990.

61. Khalid F.M. Islam and the Environment: Social and Economic Dimensions of Global Environmental Change. Vol. 5., Encyclopedia of Global Environmental Change, P. Timmerman (ed), John Wiley \& Sons, Chichester, 2002.

62. Khan D.M. Environmental Preservation and Tree Plantation in Islam. Dhaka, Dhanmondi Publ., 2011. 63. Nasr S.H. Islam and Environmental Crisis, in Spirit and Nature. S.C. Elder, ed., Boston, Beacon Press, 1992.

64. Ozdemir I. Towards An Understanding of Environmental Ethics from a Qur'anic Perspective. In: Islam and Ecology, A 
Bestowed Trust, R. C. Foltz, et al. (Eds.), Harvard University Press, 2003, pp. 1-37.

65. Sardar Z. The Touch of Midas: Science, Values and Environment in Islam and the West. Manchester, Manchester University Press, 2006, $253 \mathrm{p}$.

66. bin Hamad N. Foundations for Sustainable Development: Harmonizing Islam, Nature and Law. (July 2017) (SJD dissertation, Elisabeth Haub School of Law at Pace University), Available at:

http://digitalcommons.pace.edu/lawdissertations/20/ (accessed 04.06.2021)

67. Selnitskaya R.S., Useinova S.R. Artifacts with arabic script in the collections of Karata, Didoi and Botlikh peoples in the collection of the Russian museum of ethnography. Islam in the modern world, 2018, vol. 14, no. 1, pp. 55-70. (In Russian) DOI: 10.22311/2074-1529-2018-14-1-55-70

68. Yarlykapov A.A. Islamic education in the North Caucasus in the past and in the present. Vestnik Evrazii [Bulletin of Eurasia]. 2003, vol. 21, no. 2, 11 p. (In Russian) 69. [How in the USSR they fought with the Arabic alphabet]. IZBA-ChITAL"Nya, 30 January 2014. Available at: https://islamdag.ru/istoriya/31077 (accessed 05.06.2021)

\section{AUTHOR CONTRIBUTIONS}

This article is a product of collaboration between a collective of Dagestan State University's Institute of Ecology and Sustainable Development and teaching staff of the Verkhnee Gakvari school in the Tsumadinskiy District of Dagestan. Guy Petherbridge conceived the study, structured it, undertook the fieldwork and formulated the article. Magomed $\mathrm{M}$. Ismailov and Shamil M. Ismailov provided advice, content and images relating to the Verkhnee Gakvari School and community. Murtazali Kh. Rabadanov, as Rector of Dagestan State University, provided guidance and support, Alimurad A. Gadzhiev, as Director of DSU's Institute of Ecology and Sustainable Development, provided guidance and logistical support. Abdulgamid A. Teymurov, Murtuzali R. Rabadanov and Abdul-Gamid M. Abdulaev provided satellite imagery and cartographic input. Madina G. Daudova edited and formatted the article for publication. All authors are equally responsible for plagiarism and self-plagiarism or other ethical transgressions.
70. Saklya-chital'nya ili mechet'? Krasnyi Dagestan [Saklareading room or mosque? Red Dagestan]. Sunday, September 13, 1925, $2 \mathrm{p}$.

71. Aliev I. Five years of struggle for a new alphabet in DASSR. Revolyutsiya i gorets [Revolution and Highlander]. 1933, no. 9(60), pp. 129-133. (In Russian)

72. Gadzhiev Kh.M. Improve the teaching of Russian in schools. Komsomolets Dagestana [Komsomolets of Dagestan]. 1939, no. 10 (875), 10 p. (In Russian)

73. Newspaper "Voice of Tsumada" on the 75th anniversary of the Tsumadinskiy District. Available at: http://tsumadasmi.ru/issues/ (accessed 07.06.2021)

74. Litvinskaya S.A., Murtazaliev R.A. Flora Severnogo Kavkaza: Atlas-opredelitel' [Flora of the North Caucasus: Identifier Atlas]. Moscow, Fiton+ Publ., 2013, 688 p. (In Russian) 75. Sefikhanov Sh.S. Lesnye resursy Dagestana [Forest Resources of Dagestan]. Makhachkala, Dagestan Book Publ., 1979, 92 p. (In Russian)

76. Andiiskii okrug [Andean District]. Available at: http://ethno-kavkaz.narod.ru/andi26.html (accessed 05.06.2021)

\section{КРИТЕРИИ АВТОРСТВА}

Эта статья является продуктом сотрудничества коллектива Института экологии и устойчивого развития Дагестанского государственного университета и преподавателей школы Верхнее Гаквари Цумадинского района Республики Дагестана. Гай Петербридж задумал эксперимент, структурировал его, провел полевые исследования и сформулировал статью. Магомед М. Исмаилов и Шамиль М. Исмаилов обеспечивали материалы и изображения Верхнего Гаквари, необходимые для исследования. Муртазали X. Рабаданов, как ректор Дагестанского государственного университета, обеспечивал руководство и поддержку. Алимурад А. Гаджиев, как директор Института экологии и устойчивого развития ДГУ, обеспечивал руководство и материально-техническую поддержку. Абдулгамид А. Теймуров, Муртузали Р. Рабаданов и Абдул-Гамид М. Абдулаев обеспечивали спутниковые снимки и картографические материалы. Мадина Г. Даудова редактировала и форматировала рукопись перед публикацией. Все авторы в равной степени несут ответственность при обнаружении плагиата, самоплагиата или других неэтических проблем.

\section{КОНФЛИКТ ИНТЕРЕСОВ}

Авторы заявляют об отсутствии конфликта интересов.
NO CONFLICT OF INTEREST DECLARATION

The authors declare no conflict of interest.

\section{ORCID}

Guy Petherbridge / Гай Петербридж https://orcid.org/0000-0001-7196-3937

Magomed M. Ismailov / Магомед М. Исмаилов https://orcid.org/0000-0003-3409-5143

Shamil M. Ismailov / Шамиль М. Исмаилов https://orcid.org/0000-0002-1317-6780

Murtazali Kh. Rabadanov / Муртазали X. Рабаданов https://orcid.org/0000-0003-1857-7652

Alimurad A. Gadzhiev / Алимурад А. Гаджиев https://orcid.org/0000-0002-7359-1951

Abdulgamid A. Teymurov / Абдулгамид А. Теймуров https://orcid.org/0000-0003-1832-7864

Murtuzali R. Rabadanov / Муртузали Р. Рабаданов https://orcid.org/0000-0002-7599-0243

Madina G. Daudova / Мадина Г. Даудова https://orcid.org/0000-0003-0456-3698

Abdul-Gamid M. Abdulaev / Абдул-Гамид М. Абдулаев https://orcid.org/0000-0001-8201-5545 